\title{
MEDICAL ETHICS
}

\section{SCIENTIFIC INTERDISCIPLINARY JOURNAL OF YAROSLAVL STATE MEDICAL UNIVERSITY AND PIROGOV RUSSIAN NATIONAL RESEARCH MEDICAL UNIVERSITY}

\author{
EDITOR-IN-CHIEF Alexander Khokhlov, corr. member of RAS, DSc (Med), professor \\ CHAIR OF EDITORIAL BOARD Alexander Chuchalin, full member of RAS, DSc (Med), professor \\ DEPUTY EDITORS-IN-CHIEF Elena Grebenshchikova, DSc (Phil), professor; Dmitry Khristenko, CSc (Hist), Associate professor \\ EDITOR Marina Syrova \\ LAYOUT EDITOR Evgeny Lukyanov \\ TRANSLATORS Ekaterina Tretiakova, Vyacheslav Vityuk, Nadezhda Tikhomirova \\ DESIGN AND LAYOUT Marina Doronina
}

\section{ASSOCIATE EDITORS}

Alexandrovsky YuA, corr. member of RAS, DSc (Med), professor (Moscow, Russia) Bagnenko SF, full member of RAS, DSc (Med), professor (Saint Petersburg, Russia) Baranov AA, DSc (Biol), professor (Krasnoyarsk, Russia)

Bierer B, professor (MA, USA)

Cambon-Thomsen A, DSc (Toulouse, France)

Crowley F, DSc, professor (Belgium)

Goryanov OA, CSc (Med), CSc (Theol), professor (Petrozavodsk, Russia)

Gusev El, full member of RAS, professor (Moscow, Russia)

Glagolev SV, Deputy Head of Bureau for Federal Quality Control of Medical Products (Moscow, Russia)

Diniz N, professor (Parana, Brazil)

lvashkin VT, full member of RAS, professor (Moscow, Russia)

lienko LI, DSc, professor (Med) (Moscow, Russia)

Haihong Zhang, professor (Beijing, China)

Kagramanyan IN, DSc (Med), Head of Institute of Leadership and Healthcare Management (Moscow, Russia)

Kukes VG, full member of RAMS, full member of RAS, professor (Moscow, Russia) Kosenko VV, CSc (Pharm) (Moscow, Russia)

Kudaibergenova T, DSc (Med), Associate professor (Bishkek, Kyrgyz Republic)

Lukyanov SA, full member of RAS, DSc (Biol), professor (Moscow, Russia)

Malikov AYa, CSc (Med) (Saint Petersburg, Russia)
Moshetova LK, full member of RAS, DSc (Med), professor (Moscow, Russia) Muthuswamy V, professor (India)

Nasonov EL, full member of RAS, professor (Moscow, Russia)

Pavlov AV, DSc (Med), professor (Yaroslavl, Russia)

Petrov VI, full member of RAS, professor (Volgograd, Russia)

Rebrikov DV, DSc (Biol), professor (Moscow, Russia)

Rozhdestvensky DA, CSc (Med) (Moscow, Russia)

Romanov BK, DSc, Associate (Med), professor (Moscow, Russia)

Safarli N, professor (Baku, Azerbaijan)

Sayamov YuN, CSc (Hist), member of Club of Rome, professor (Moscow, Russia) Sarymsakova B, DSc (Med), professor (Astana, Kazakhstan)

Sedova NN, DSc (Phil), SJD (Volgograd, Russia)

Shimaa E, Associate professor (Egypt)

Shlyakhto EV, full member of RAS, DSc (Med), professor (Saint Petersburg, Russia) Sozinov AS, DSc (Med), professor (Kazan, Russia)

Sokolchik VN, CSc, Associate professor (Med) (Minsk, Belarus)

Starodubov VI, full member of RAS, DSc (Med), professor (Moscow, Russia)

Tishchenko PD, DSc (Phil), professor (Moscow, Russia)

Tkachuk VA, full member of RAS, DSc (Med), professor (Moscow, Russia)

Yanushevich OO, full member of RAS, DSc (Med), professor (Moscow, Russia)

\section{EDITORIAL BOARD}

Bogdanova NV, CSc (Med) (Dmitrograd, Russia) Dmitrieva EV, CSc (Sociol) (Moscow, Russia) Durnev AD, corr. member of RAMS, corr. member of RAS, professor (Moscow, Russia) Firsov DE, DSc (Cult), CSc (Phil) (Yaroslavl, Russia)

Guskova TA, corr. member of RAMS, corr. member of RAS, DSc (Med), professor (Moscow, Russia)

Kovtun OP, corr. member of RAS, DSc (Med), professor (Yekaterinburg, Russia)

Kontsevaya AV, DSc (Med) (Moscow, Russia)

Korotkova AV, CSc (Med) (Moscow, Russia)

Lileeva EG, CSc (Med), Associate professor (Yaroslavl, Russia)

Martynov Al, CSc (Med) (Moscow, Russia)
Mosolov SN, DSc (Med), professor (Moscow, Russia) Mizernitsky YuL, DSc (Med), professor (Moscow, Russia)

Mikhailova NA, CSc (Biol) (Saratov, Russia)

Pavlov ChS, DSc (Med), professor (Moscow, Russia)

Roshal LM, DSc (Med), professor (Moscow, Russia) Semenova NV, DSc (Med) (Saint Petersburg, Russia)

Teplova AV, CSc (Hist), professor (Minsk, Belarus)

Vlasov YaV, DSc (Med), professor (Samara, Russia)

Volchenko NN, DSc (Med) (Moscow, Russia)

Zhilyaev EV, DSc (Med) (Moscow, Russia)

SUBMISSION https://medet.rsmu.press/

CORRESPONDENCE https://medet.rsmu.press/

COLLABORATION editor@rsmu.press

ADDRESS Ostrovityanov Street 1, Moscow, 119997, Russia

ssue DOl: 10.24075/medet.2021-01

The mass media registration certificate серия ПИ № ФС77-81021 от 02 июня 2021 г. Founders: Yaroslavl State Medical University (Yaroslavl, Russia)

Pirogov Russian National Research Medical University (Moscow, Russia).

Publisher: Pirogov Russian National Research Medical University; adress: Ostrovityanov Street 1, Moscow, 119997, Russia

The journal is distributed under the terms of Creative Commons Attribution 4.0 International License www.creativecommons.org

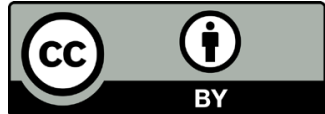

Approved for print 31.03.202 


\title{
МЕДИЦИНСКАЯ ЭТИКА
}

\author{
НАУЧНЫЙ МЕЖДИСЦИПЛИНАРНЫЙ ЖУРНАЛ \\ ЯРОСЛАВСКОГО ГОСУДАРСТВЕННОГО МЕДИЦИНСКОГО УНИВЕРСИТЕТА И \\ РОССИЙСКОГО НАЦИОНАЛЬНОГО ИССЛЕДОВАТЕЛЬСКОГО МЕДИЦИНСКОГО \\ УНИВЕРСИТЕТА ИМ. Н. И. ПИРОГОВА
}

ГЛАВНЫЙ РЕДАКТОР Александр Хохлов, член-корр. РАН, Д. М. Н., профессор

ПРЕДСЕДАТЕЛЬ РЕДАКЦИОННОГО СОВЕТА АЛЕКСаНДр ЧУЧалИН, акаДемИК РАН, Д. М. Н., Профессор

ЗАМЕСТИТЕЛИ ГЛАВНОГО РЕДАКТОРА Елена Гребенщикова Д. филос. Н., профессор; Дмитрий Христенко, к. ист. н., доцент

РЕДАКТОРЫ Марина СЫрова

ТЕХНИЧЕСКИЙ РЕДАКТОР ЕВГеНИЙ ЛУКЬЯНОВ

ПЕРЕВОДЧИКИ Екатерина Третьякова, Вячеслав Витюк, Надежда Тихомирова

ДИЗАЙН И ВЕРСТКА Марины Дорониной

\section{РЕДАКЦИОННАЯ КОЛЛЕГИЯ}

Ю. А. Александровский, член-корр. РАН, д. М. Н., профессор (Москва, Россия) С. Ф. Багненко, академик РАН, д. М. Н. профессор (Санкт-Петербург, Россия)

А. А. Баранов, д. б. н., профессор (Красноярск, Россия)

Б. Бирер, профессор (Массачусетс, США)

О. А. Горянов, К. М. Н., кандидат богословия, профессор (Петрозаводск, Россия)

Е. И. Гусев, академик РАН, профессор (Москва, Россия)

С. В. Глаголев, зам. начальника Управления организации государственного

контроля качества медицинской продукции (Москва, Россия)

Н. Диниз, профессор (Парана, Бразилия)

В. Т. Ивашкин, академик РАН, д. М. Н., профессор (Москва, Россия)

Л. И. Ильенко, д. М. Н., профессор (Москва, Россия)

И. Н. Каграманян, д.м.Н., руководитель Института лидерства и управления

здравоохранением Сеченовского ун-та (Москва, Россия)

В. Г. Кукес, академик РАМН, академик РАН, профессор (Москва, Россия)

Ф. Кроули, доктор наук, профессор (Бельгия)

В.В. Косенко, К. фарм. н. (Москва, Россия)

Т. Кудайбергенова, д. М. Н., доцент (Бишкек, Киргизия)

С.А. Лукьянов, академик РАН, д. б. Н., профессор (Москва, Россия)

А. Я. Маликов, К.м.Н. (Санкт-Петербург, Россия)

Л. К. Мошетова, академик РАН, д. М. Н., профессор (Москва, Россия)

А. А. Мохов, д. Ю. Н., профессор (Москва, Россия)

В. Мутузвами, профессор (Индия)

\section{РЕДАКЦИОННЫЙ СОВЕТ}

Е. В. Дмитриева, д. с. Н. (Москва, Россия)

Н. В. Богданова, К. М. Н. (Дмитроград, Россия)

я. В. Власов, д. М. Н., профессор (Самара, Россия)

Н. Н. Волченко, д. М. Н. (Москва, Россия)

Т. А. Гуськова, член-корр. РАМН, член-корр. РАН, Д. М. Н., профессор (Москва, Россия)

А. Д. Дурнев, член-корр. РАН, д. М. Н., профессор (Москва, Россия)

Е. В. Жиляев, Д. М. Н. (Москва, Россия)

О.П. Ковтун, член-корр. РАН, д. м. Н., профессор (Екатеринбург, Россия)

А. В. Концевая, д. М. Н. (Москва, Россия)

А. В. Короткова, К. М. Н. (Москва, Россия)

ПОДАЧА РУКОПИСЕЙ https://medet.rsmu.press/

ПЕРЕПИСКА С РЕДАКЦИЕЙ https://medet.rsmu.press/

СОТРУДНИЧЕСТВО editor@rsmu.press

АДРЕС РЕДАКЦИИ ул. Островитянова, д.1, г. Москва, 119997
Е. Л. Насонов, академик РАН, профессор (Москва, Россия)

А. В. Павлов, д. М. Н., профессор (Ярославль, Россия)

В. И. Петров, академик РАН, профессор (Волгоград, Россия)

Д. В. Ребриков, д. б. н., профессор (Москва, Россия)

Д. А. Рождественский, К. М. Н. (Москва, Россия)

Б. К. Романов, д. М. Н., доцент (Москва, Россия)

Н. Сафарли, профессор (Баку, Азербайджан)

ю. Н. Саямов, к. ист. Н., профессор, член Римского клуба (Москва, Россия)

Б. Сарымсакова, д. М. Н., профессор (Астана, Казахстан)

Н. Н. Седова, д. филос. Н., д. ю. Н., профессор (Волгоград, Россия)

А. С. Созинов, д. М. Н., профессор (Казань, Россия)

В.Н. Сокольчик, к.филос.н., доцент (Минск, Беларусь)

В. И. Стародубов, академик РАН, д.м.Н., профессор (Москва, Россия)

П. Д. Тищенко, д. филос. н., профессор (Москва, Россия)

В. А. Ткачук, академик РАН, д. М. Н., профессор (Москва, Россия)

А. Томсен-Кабон, доктор наук (Тулуза, Франция)

ч. Хайхун, профессор (Пекин, Китай)

Н. В. Чудова (Москва, Россия)

Е. Шимаа, доцент (Египет)

Е. В. Шляхто, академик РАН, д.м.Н., профессор Санкт-Петербург, Россия)

О. О. Янушевич, академик РАН, д.м.Н., профессор (Москва, Россия)
Е. Г. Лилеева, К. М. Н., доцент, (Ярославль, Россия)

А. И. Мартынов, К. М. Н. (Москва, Россия)

С. Н. Мосолов, д. М. Н., профессор (Москва, Россия)

Ю. Л. Мизерницкий, д. М. Н., профессор (Москва, Россия)

Н. А. Михайлова, К. б. Н., (Саратов, Россия)

ч. С. Павлов, д. М. Н., профессор (Москва, Россия)

л. М. Рошаль, д. М. Н., профессор (Москва, Россия)

Н. В. Семенова, д. м. Н. (Санкт-Петербург, Россия)

А. В. Теплова, К. ист. н, профессор (Минск, Белоруссия)

Д. Е. Фирсов, доктор культурологии, к. филос. Н. (Ярославль, Россия)

DOI выпуска: 10.24075/medet.2021-01

Свидетельство о регистрации средства массовой информации серия ПИ № ФС77-81021 от 02 июня 2021 г. Учредители: Ярославский государственный медицинский университет (Ярославль, Россия);

Российский национальный исследовательский медицинский университет имени Н.И. Пирогова (Москва, Россия).

Издатель: Российский национальный исследовательский медицинский университет имени Н.И. Пирогова; адрес: ул. Островитянова, д.1, г. Москва, 8(495)434-03-29 Журнал распространяется по лицензии Creative Commons Attribution 4.0 International www.creativecommons.org

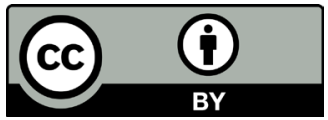

Подписано в печать 31.03.2021 
MEDICALETHICS

MEАИЦИНСКАЯ ЭТИКА

Contents

Содержание

On the $75^{\text {th }}$ anniversary of the beginning of the Nuremberg trials and the creation of the nuremberg code: global relevance and enduring lessons Chuchalin AG, Sayamov YuN

K 75-летию начала Нюрнбергских процессов и создания Нюрнбергского кодекса: глобальное значение и непреходящие уроки А.Г. Чучалин, Ю. Н. Саямов

ORIGINAL RESEARCH

Respecting patient's autonomy: informed consent in current medicine Grebenshchikova EG, Chuchalin AG

Уважая автономию пациента: добровольное информированное согласие в современной медицине Е.Г. Гребенщикова, А. Г. Чучалин

ORIGINAL RESEARCH

Awareness as a criterion of legality of obtaining the patient's consent to medical intervention

Pishchita AN, Alekseev VA, Borisov KN

Информированность как критерий законности получения согласия пациента на медицинское вмешательство А. Н. Пищита, В. А. Алексеев, К.Н. Борисов

ORIGINAL RESEARCH

The inherent right to make a mistake

Zorin NA

Неотьемлемое право совершить ошибку (об информированном согласии)

Н. А. Зорин

ORIGINAL RESEARCH

Informed consent: from historic roots towards the red line of modern crises in infectious diseases

Kubar OI, Bichurina MA, Romanenkova NI

Концепция информированного согласия от исторических корней до красной линии современных кризисных ситуаций

в инфекционной патологии

О. И. Кубарь, М. А. Бичурина, Н. И. Романенкова

ORIGINAL RESEARCH

Ethical aspects of the informed consent during covid-19 vaccination

Zorin KV, Gurevich KG

Этические аспекты добровольного информированного согласия при вакцинации против COVID-19

К. В. Зорин, К. Г. Гуревич

ORIGINAL RESEARCH

Educating relatives of ICU patients for better compliance: our experience

Saetgaraev AK, Maximov IL, Guryleva ME, Grigoreva IA

Опыт работы с пациентами реанимационного отделения и их родственниками по информированию и оптимизации комплайнса

А. К. Саетгараев, И. Л. Максимов, М. Э. Гурылева, И. А. Григорьева

ORIGINAL RESEARCH

Ethical issues in disclosing diagnostic and prognostic information to cancer patients

Vvedenskaya EV, Lepkova NV, Egorova AV

Этические проблемы информирования онкологических пациентов в России

Е. В. Введенская, Н. В. Лепкова, А. В. Егорова

ORIGINAL RESEARCH

Informed consent in Russia: misuse and abuse

Mylnikova IS

Информированное согласие в России: искажения и злоупотребления

И. С. Мыльникова

ORIGINAL RESEARCH

What do members of research ethics committees know about their organizational and operational aspects? Chudova NV, Tsyzman LG

Осведомленность специалистов по вопросам организации и деятельности локальных этических комитетов

Н. В. Чудова, Л. Г. Цызман 




\section{Dear colleagues!}

Biomedical research is becoming increasingly extensive, needed and economically justified. We are witnessing the advent of novel drugs, medical products and diagnostic techniques, a wealth of genetic, regenerative medicine and cellular therapy studies, and the emergence of new information, reproductive and other technologies. More concerns are being voiced about possible social, moral, psychological, and economic implications of scientific discoveries and findings. In Russia, there are ethics committees and councils operating at various levels. They address and solve important challenges but their mandate is limited to a range of specific problems. The evolution of Russian science and the competitive strength of Russian inventions on the international market depend on the harmonization of bioethics requirements in Russia and abroad, as well as on the eagerness of Russian researchers to jointly tackle complex problems associated with ethical assessment of scientific breakthroughs. In this light, an exchange of expert opinions is now essential like never before, and we hope that the Medical Ethics bulletin will become a platform for addressing a wide range of issues related to bioethics.

I am delighted to introduce you to the first issue of the Medical Ethics bulletin and its founders: Pirogov Russian National Research Medical University, Yaroslav State Medical University, and the Faculty of Global Studies at Lomonosov Moscow State University, the leading partner of the journal. The journal will be published online https://medet.rsmu.press/general?lang=ru and in print 4 times a year. We hope that the interdisciplinary nature of the journal and the significance of the questions raised will attract specialists, medical and non-medical researchers, teachers, students, postgraduates, clinicians and pharmacists, and will facilitate further development of bioethics in Russia.

It is our pleasure to receive your manuscripts and cooperation. We cordially wish success in future endeavors to all our readers.

Editor-in-Chief Alexander L. Khokhlov 


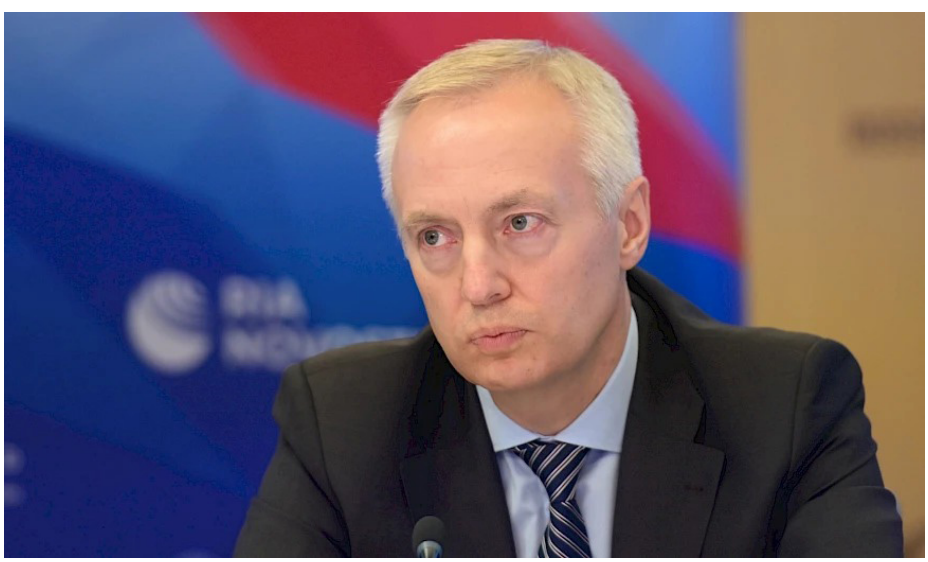

\section{Дорогие коллеги!}

В последнее время биомедицинские исследования становятся более масштабными, необходимыми и экономически востребованными. Появляются новые лекарственные препараты, медицинские изделия, диагностические процедуры, исследования в области генетики, регенеративной медицины и биомедицинских клеточных продуктов, информационных, репродуктивных и др. технологий. Всё чаще выражается обеспокоенность широких слоёв общественности о возможных социальных, моральных, психологических и финансовых последствиях полученной в этих исследованиях информации. В настоящее время в Российской Федерации существуют этические комитеты/советы различного уровня. Все эти организации решают важные задачи, но сфера компетенции каждой из них во многом ограничена определенным кругом вопросов, а также ведомственными рамками. Развитие российской науки, обеспечение конкурентоспособности отечественных разработок на мировом уровне сопряжено с дальнейшей гармонизацией отечественных и международных требований в области биоэтики, объединением усилий отечественных ученых для решения сложных задач этической оценки прорывных научных направлений. В связи с этим обмен мнениями на профессиональном уровне в области биоэтики в настоящее время как никогда актуален, и мы надеемся, что журнал «Медицинская этика» послужит площадкой для решения многих вопросов в этом направлении.

Мне очень приятно представить первый номер журнала «Медицинская этика» в обновленном составе учредителей: ФГАОУ ВО Российский национальный исследовательский медицинский университет имени Н.И. Пирогова Министерства здравоохранения Российской Федерации, ФГБОУ ВО Ярославский государственный медицинский университет Министерства здравоохранения Российской Федерации, а также факультет глобальных процессов ФГБОУ ВО Московского государственного университета им. М. В. Ломоносова в качестве ведущего партнера издания. Журнал будет издаваться 4 раза в год как в электронном виде (https://medet.rsmu.press/general?lang=ru), так и на бумажном носителе. Мы надеемся, что междисциплинарный характер журнала, актуальность поднятых вопросов вызовет интерес у специалистов разного профиля, ученых медицинских и немедицинских специальностей, педагогов, студентов, аспирантов, практических врачей и провизоров, будет способствовать дальнейшему развитию биоэтики в Российской Федерации.

Искреннее рады вашим публикациям и сотрудничеству с журналом. Желаю всем успехов в вашей профессиональной деятельности!

Главный редактор журнала «Медицинская этика»

Александр Леонидович Хохлов 


\title{
ON THE 75TH ANNIVERSARY OF THE BEGINNING OF THE NUREMBERG TRIALS AND THE CREATION OF THE NUREMBERG CODE: GLOBAL RELEVANCE AND ENDURING LESSONS
}

Chuchalin $\mathrm{AG}^{1} \otimes$, Sayamov YuN²

Pirogov Russian National Research Medical University, Moscow, Russia

2 Lomonosov Moscow State University, Moscow, Russia

The article reveals the significance of the Nuremberg Trials for rethinking the moral foundations of medicine, investigates the role of the Nuremberg Code in the establishment of voluntary informed consent as a mandatory component of clinical trials and procedures and assesses the impact thereof on the international legal regulation of healthcare. The authors emphasize the importance of the Nuremberg lessons for understanding the ethical challenges that came into foreground in the 21 st century due to the development of artificial intelligence, human genome editing technologies and the emergence of the new forms of parenting largely backed by the new reproductive technologies.

Keywords: Nuremberg trials, Nuremberg code, informed consent

Author contribution: Research concept and design — Chuchalin AG; text writing and editing — Sayamov YuN.

$\triangle$ Correspondence should be addressed: Alexander G. Chuchalin

Ostrovityanova st. 1, Moscow, 117997; Chuchalin@inbox.ru

Received: 12.02.2021 Accepted: 25.03.2021 Published online: 31.03.2021

DOI: $10.24075 /$ medet.2021.002

\section{К 75-ЛЕТИЮ НАЧАЛА НЮРНБЕРГСКИХ ПРОЦЕССОВ И СОЗДАНИЯ НЮРНБЕРГСКОГО КОДЕКСА: ГЛОБАЛЬНОЕ ЗНАЧЕНИЕ И НЕПРЕХОДЯЩИЕ УРОКИ}

\author{
А. Г. Чучалин ${ }^{1 凶}$, Ю. Н. Саямов \\ ${ }^{1}$ Российский национальный исследовательский медицинский университет имени Н. И. Пирогова, Москва, Россия \\ ${ }^{2}$ Московский государственный университет им. М. В. Ломоносова, Москва, Россия
}

В статье раскрывается значение Нюрнбергского процесса для переосмысления нравственных оснований медицины; рассматривается роль Нюрнбергского кодекса в становлении добровольного информированного согласия в клинической практике и в клинических исследованиях, а также его влияние на международное нормативно-правовое регулирование сферы здравоохранения. Авторы акцентируют внимание на значении уроков Нюрнберга для понимания этических вызовов, которые актуализировались в XXI веке в результате развития технологий искусственного интеллекта, редактирования генома человека и становления новых форм родительства, во многом связанных с достижениями новых репродуктивных технологий.

Ключевые слова: Нюрнбергский процесс, Нюрнбергский кодекс, добровольное информированное согласие

Вклад авторов: концепция и дизайн исследования - Чучалин А. Г.; написание и редактирование текста — Саямов Ю. Н.

$\triangle$ Для корреспонденции: Чучалин Александр Григорьевич

ул. Островитянова, д. 1, г. Москва, 117997; Chuchalin@inbox.ru

Статья получена: 12.02.2021 Статья принята к печати: 25.03.2021 Опубликована онлайн: 31.03 .2021

DOI: $10.24075 /$ medet.2021.002

The year 2020 was marked with the $75^{\text {th }}$ anniversary of the Great Victory and the subsequent anniversaries of events that could not have happened without this historic achievement. The war unprecedented in its monstrosity, victim count and scale of destruction generated a common desire and firm determination to never again allow such a catastrophe and to punish the guilty. The desire transformed into the International Military Tribunal (IMT) established in 1946 to try the ideologists and leaders of Nazism and militarism guilty of the horrific crimes. This was a trial by the peoples.

Celebrating the $75^{\text {th }}$ anniversary of these events, it is necessary to dwell on the global significance and enduring lessons of the IMT's condemnation of the Nazi leaders who unleashed the world massacre, and specifically discuss the atrocities committed under their leadership, including in the field of medicine. This discussion seems especially relevant today, in the light of the ongoing processes and emergence of the new threats and challenges affecting health, safety of people and human rights.

The International Military Tribunal and subsequent trials took place in the Bavarian city of Nuremberg, where Nazis held their congresses and declared the insane misanthropic ideas and the right of the Germans to dominate the world as a superior race.
The Nuremberg Trials became the starting point of a new era in the development of world civilization and global legal consciousness. They established the legal foundations and principles of the post-war world order, which were adopted by the newly created UN and essentially back the current understanding of human rights and freedoms.

Nuremberg Trials formulated the concepts of crimes against peace and humanity, legally qualified and condemned the unprecedented acts by the criminal Hitlerite regime, such as the mass extermination of people in the "death factories", inhuman treatment of the civilian population and concentration camp prisoners, medical experiments involving the prisoners.

The results of the Nuremberg Trials boosted evolution of the international law and lead to a real breakthrough in the process of regulations development. They gave rise to the new legal culture that enshrined the ideas of peace, prevention of war and protection of human rights and freedoms in the national legislations.

The lessons of Nuremberg include both the IMT outcomes and the results of the twelve Nuremberg trials that followed. Since Nuremberg was in the American occupation zone, the Allies agreed that the proceedings will be supported by the American military tribunal. Among them, the trial of the Nazi killer doctors occupies a special place. It lasted from December 
9, 1946 to August 20, 1947. The hall of the Nuremberg Palace of Justice selected for this trial was that where the key war criminals of the Third Reich were tried. Twenty most odious Nazi criminal doctors, 2 medical officials and 1 lawyer were accused at the trial, but that is not the only and, probably, not the most important fact underpinning the significance of these proceedings. There is an outcome of this trial that is at least no less significant, namely, the development of the Nuremberg Medical Code. It relied on the proceedings' results and was the first document since the works of Hippocrates to establish the principles of medical ethics, which remain current to this day. There were 1471 documents reviewed and 177 participants of the experiments [1] heard at the trial. The evidence and the testimonies revealed a horrifying picture of experiments that forcefully involved Nazi concentration camp prisoners stripped of all rights. Following requests from the air and naval forces, the participants were subjected to murderous pressure in a pressure chamber, simulating a fall from a great height, and immersed in ice-cold water to understand the limits of human survival in this environment. They were murdered for the purpose of replenishing the collection of skulls justifying superiority of the German race; forcibly sterilized, vaccinated, infected with typhus and yellow fever; had their limbs cut off and implanted to others, which ended in painful death of both the donor and the recipient. The effect of chemical weapons , phosgene and mustard gas, was investigated on living people, same as the medicinal properties of sulfonamides. For the latter purpose, test subjects had their bones crushed and phlegmons induced, broken glass and rusty nails poured into their wounds. The scope of the forced euthanasia program was terrifying. This program was aimed at "cleansing" out the people whom the Nazis considered unworthy, i.e. the disabled, people with chronic diseases, mental and other disabilities. At least 100000 people were proven violently killed under this program, with the predominant kill pattern being phenol injection to the heart. However, since most of the documents were destroyed, the researchers suggest that the number of victims of this program could have actually amounted to about 1 million people and more [2].

The only woman among the convicts was Dr. Gertha Oberheuser, who, like Dr. Karl Brandt, the main accused, Hitler's personal doctor and curator of the inhuman medical experiments, justified her actions by orders of the leadership. In this connection, the Nuremberg Trials declared it was unacceptable to justify the cruelty, inhuman attitude of a medical worker to a patient and any person by orders that violate the "Do no harm" principle. The code adopted in Nuremberg stated that "it is a personal duty and responsibility which may not be delegated to another with impunity" [3].

The basic principle formulated by the Nuremberg Tribunal in the context of the Nuremberg Trials, is that in order to conduct an experiment on a person, a voluntary informed consent should be received from this person after he/she has been provided with full information about the nature, duration and purpose of the experiment, methods of its implementation, the alleged inconveniences and dangers associated with the experiment, and, finally, about the possible physical or mental consequences that may arise as a result of participation in the experiment [3]. It was the first time in the history of mankind when the principle of voluntary informed consent was proclaimed. In the field of medicine, paternalism was replaced by respect for dignity and human rights in making health-related decisions, this respect ensured by the process of obtaining voluntary informed consent $(\mathrm{VIC})$. Medical ethics saw the doctor-patient relationship undergo qualitative changes.
The principles formulated in the Nuremberg Code became the basis for many international and national laws in the field of medical research involving human beings.

In Russia, part 2 of Article 21 of the Basic Law, the Constitution of the Russian Federation, proclaims that "No one should be subjected to torture, violence, other cruel or degrading treatment or punishment. No one can be subjected to medical, scientific or other experiments without voluntary consent" [4]. It follows from this statement that medical experiments carried out on a person fall under the category of torture, violence, cruelty and treatment that degrades human dignity. In Fundamentals of the Russian Federation Law "On the Protection of Citizens' Health", the principles of the Nuremberg Code are reflected in Article 32, which establishes the need for voluntary informed consent to any medical intervention, and in Article 43, which requires the same for medical experiments. In particular, it reads: "Any biomedical research involving a person as an object can be carried out only after obtaining the written consent of this citizen. A citizen cannot be forced to participate in biomedical research.

In the context of obtaining consent for biomedical research, the citizen should be provided with information about the goals, methods, side effects, possible risks, duration and expected results of the research. The citizen has the right to refuse to participate in the research at any stage" [5].

The Nuremberg Code had a significant impact on the subsequent development of a number of international documents that played an important role in the formation of the post-war world order. One of these documents is the Universal Declaration of Human Rights adopted by the UN General Assembly on December 10, 1948 [6].

A year earlier, the global medical community united into the World Medical Association (WMA) at its first general assembly in Paris (September 1947). A kind of the world medical parliament was created, one uniting doctors of the world and setting international standards for medical activity, binding on medical professionals of all countries. The WMA Code of Medical Ethics was influenced by the Nuremberg Code; it includes the main provisions thereof. Together with the Nuremberg Code, the WMA Code supported widespread adoption and application of the principle of VIC. For more than seven decades that followed, WMA became the center spreading the ethical principles applied in healthcare and medicine. Another important milestone is adoption of the Declaration of Geneva, a modern version of the Hippocratic Oath, which took place at the second general assembly of the WMA in Geneva in September 1948. The Declaration of Geneva and the ethical principles applied in medicine were supplemented at the WMA assemblies in Helsinki (1964), Tokyo (1975), Venice (1983), Hong Kong (1989), South Africa (1996), Edinburgh (2000), Washington (2002), Tokyo (2004), Seoul (2008), Brazil (2013). The mere listing of these assemblies testifies to the importance of ethical issues in professional discussions held within the world medical community.

The Nuremberg Code and the Universal Declaration of Human Rights formed the basis for the development of the Universal Declaration on Bioethics and Human Rights, a fundamental document prepared by the UNESCO experts and adopted at the UNESCO General Conference session of October 19, 2005. The Russian philosophers B.G. Yudin and R.G. Apresyan made a great contribution to the preparation of this comprehensive document. The Declaration considers ethical principles quite broadly, reflecting the activities of human beings all around. The key principles stated in the Declaration are covered in its main articles: 
Article 3 - Human dignity and human rights.

Article 4 - Benefit and harm.

Article 5 - Autonomy and individual responsibility.

Article 6 - Consent.

Article 7 - Persons without the legal capacity to consent.

Article 8 - Respect for human vulnerability and personal integrity.

Article 9 - Privacy and confidentiality.

Article 10 - Equality, justice and equity.

Article 11 - Non-discrimination and non-stigmatization.

Article 12 - Respect for cultural diversity and pluralism.

Article 13 - Solidarity and cooperation.

Article 14 - Social responsibility and health.

Article 15 - Sharing of benefits.

Article 16 - Protecting future generations.

Article 17 - Protection of the environment, the biosphere and biodiversity.

The sections covering environmental ethics were included for the first time. Bioethics includes a variety of human activities and their ethical aspects: availability of medical care, clinical research, reproductive health, genome editing and human cloning, donation ethics, environmental ethics, biotechnology and nanotechnology [7].

Intergovernmental and expert committees on bioethics were established within UNESCO. Their activity is guided by the dignity and respect principle formulated in the Nuremberg Code. It should be emphasized here that this principle underpins each fundamental international document in the field of medical ethics.

Also noteworthy are the ethical principles of scientific research developed in the United States of America. In 1974, the US National Commission for the Protection of Human Subjects of Biomedical and Behavioral Research was tasked with defining the fundamental ethical criteria for such research efforts. In 1979, the specialists that tackled the task presented the Belmont Report, the main provisions of which are:

1. Respect of persons.

2. Beneficence.

3. Justice.

Currently, the Belmont Report is the key source of ethical principles for research in the United States.

Ethical problems became especially urgent in the 21st century. The agenda was extended with the ethical challenges peculiar to the present, those related to artificial intelligence, human genome editing and the new patterns of parenting. XXI.

The infectious diseases of the 21 st century are of particular urgency. Human kind faced SARS (2002), MERS (2012), COVID-19 caused by SARS-COV-2 for the first time in its history. It is believed that coronavirus mutations are behind all these vital diseases. The 2009 influenza pandemic should also be mentioned in the list of this century's infectious diseases. The causative agent of that influenza was the California strain of H1N1. The pandemic was the first time when it was found to circulate in the human population. Some other diseases causing grave concern are the Ebola fever and the Zika disease, the former spread in Africa and the latter in Latin America. There is also another topic discussed hotly in the same context as the new infectious diseases: re-emergence of the "old" infections (smallpox etc). These new challenges to civilization highlight human vulnerability and raise questions about the moral foundations of the modern society. In the way of reaction thereto, in May of 2020 there was published the Guide to Informed Consent Compliance [9]. This document covers current approaches to the interpretation of the concept of VIC.XXI
The urgency of this matter is also driven by the need for large-scale studies triggered by the COVID-19 pandemic. The scope and intensity of the relevant research efforts are unprecedented. They have to do with infectious disease epidemiology, prevention, antiviral therapy, pneumonia therapy and intensive care methods, as well as testing of the next generation vaccines. There arose a number of ethical questions that were widely discussed not only by the professional medical community but by the general public, too. In this regard, the relevance of voluntary informed consent has come to the foreground, emphasizing the need to strictly observe the traditional ethical principles of medical treatment: Primum non necere! (First of all, do no harm!) Voluntas aegroti suprema lex! (The patient's will is the highest law!) Salus aegroti suprema lex! (The patient's well-being is the highest law!)

All activities of all medical professionals should pursue interests of the sick person. In this connection, it is also necessary to abandon paternalism for the principle of voluntary informed consent. Hereafter, we consider the semantic component of each of these keywords in detail.

"Voluntary" implies a deep respect for the dignity of the human person, his/her rights and freedoms, the possibility of independent choice. Article 3 of the Declaration on Bioethics and Human Rights addresses human dignity. It is an intrinsic value of a person capable of thinking, feeling, communicating verbally, choosing freely, independent behavior and creative activity. Ethics is the science studying the human being (N.A. Berdyaev); human dignity is a goal in itself. Different cultural and moral traditions and different types of societies have different understandings of the human dignity. In the academic dictionary of the Russian Academy of Sciences, dignity's definition states it is the person's awareness of his high value as a member of a group, which makes this person behave as a member of this group should behave. As an ethical concept, "voluntary" also includes the legal side. There is but a fine line between right and duty, so it is important to return to the interpretation of the person's dignity and his/her behavior as a member of the group to which he/she belongs.

Voluntary decision-making implies the person making the decision is under no external pressure and can make the health-related decisions freely. Thus, "voluntary" implies respect for the person's dignity, his/her rights and obligations, and for the fact that he/she makes his decisions as a free person. Analyzing the problem of freedom, Fedor Dostoevsky defined it as follows: freedom is not restraining oneself, but controlling oneself. N.A. Berdyaev, the philosopher of freedom, relies on the Dostoevsky's definition of freedom and adds that ethics is the philosophy of freedom.

Finally, "voluntary" implies person's autonomy and individual responsibility. Article 5 of the Declaration on Bioethics and Human Rights covers the concepts of autonomy and responsibility.

Autonomy is the person's self-determination ability, independent decisions, actions and assessments. Autonomy implies freedom from paternalistic interference, the person's ability to act on the basis of rational principles and rules in accordance with how this person understands his own good, personal dignity and happiness. According to Kant, autonomy is the ability of the will to independently establish the law of its action. Under the utilitarian approach, autonomy is the ability of a person to act in accordance with his/her own preferences.

The second part of Article 5 is about liability. Responsibility is a person's awareness of the duty to make decisions, act appropriately to his/her obligations, for example, to parents. 
In ethics, the concepts of autonomy and responsibility are interconnected. If there is no responsibility, autonomy turns into arbitrariness: making a decision, a person does not take into account the interests of others.

Thus, the term "voluntary" should, first of all, mean respect for the dignity of the human person, his/her rights and freedom, as well as autonomy and responsibility.

The very text of the VIC is what its preparation revolves about. This document should not be considered as a piece of paper that needs a signature, i.e. as some formal procedure. Naturally, the question arises as to who is the author of this document: the sponsor, the scientific leader of the project, the organization of sick patients? Initially, the drafting of the document is initiated by the sponsor and reviewed at the topical expert meeting with participation of the scientific leader. The next important stage is the approval of the document. The preference should be given to the science and practice societies (several of them, in some cases) that can approve the VIC text. However, such a society needs to have a body authorized to approve the such a text. In the US, for example, the US Food and Drugs Administration (FDA) includes the Institution Review Board (IRB), which has approval of VIC texts among its duties. The Association of American Physicians also plays an important role. Finally, the relevant ethics committee reviews the VIC text at a meeting. The ethics committee experts review the suggested study as a whole, but they pay special attention to the said text. Practice shows that this part of a research project is the most vulnerable. The experience of international pharmaceutical companies can serve as a benchmark. As for the Russian research projects, in this part they usually contain comments from the ethics committee. The reason is that both the sponsor and the scientific leaders of the project typically lack the required skill, which translates into the need to train them to compile the informed consent texts.

The basis element of the informed consent is the part that details purpose of the study, its duration and research procedures.

An important section of the VIC is the description of the possible adverse reactions. In some studies, it is necessary to consider adverse reactions to treatment or instrumental examinations. This part of the document should be carefully analyzed by experts and explained to the patient in an understandable and accessible form. The witness is responsible for controlling how clearly the doctor explains the details of the $\mathrm{VIC}$ to a sick person or to his family members and other persons responsible for the sick person. The involvement of the witness, as mentioned above, is a relatively new condition for the VIC document. The informed consent witness must be convinced that the doctor has described the possibility of development of adverse reactions in an understandable manner, and that the patient has understood them. This is the role of the witness. $\mathrm{He} /$ she should note in the document that the VIC process was carried out professionally and in compliance with the established requirements.

When considering a research project, the doctor should also discuss with the patient the benefits that the latter receives from participating in this research or from application of the certain methods of treatment and examination.

The participating person's financial interest occupies a special place. Before enrolling, he/she must receive clear and concise information regarding the financial compensation for the participation. Moreover, the participant should have the right to leave the study at any stage thereof.

Current requirements for the text of informed consent allow two forms thereof: a detailed text and a short form, with declaration of the project itself and the objectives of the study.
In some special cases, a life-threatening disease may necessitate VIC acceleration. This is a state-level decision made by the healthcare authorities. A case in question is that of registration of the new generation vaccines designed to prevent spread of SARS-COV-2: the circumstances called for a shorter vaccine testing procedure than is usually customary. Another special case is obtaining a VIC from persons who, for various reasons, cannot make decisions on their own. First of all, this applies to patients with impaired cognitive function.

Ethical issues permeate the entire process of developing and passing the voluntary informed consent to practice. The ethical aspects of placebo and nocebo must be emphasized. The latter problem is rarely covered in Russian literature. The nocebo effect is the process of deterioration of the patient's health under the influence of information that is communicated to him/her by the doctor or medical personnel. There are following forms of nocebo distinguished: psychosomatic health deterioration caused by the expected adverse reactions; psychosomatic deterioration manifesting in the desire to have health deteriorating and, finally, actual deterioration of health of the patient due to the his/her initial attitude to such a turn of events. Unfortunately, current studies do not factor in and analyze the effects of placebo and nocebo sufficiently, which is especially relevant for the latter.

It is no coincidence that the article emphasizes the historical role of the Nuremberg Code, which formed the basis of the Universal Declaration of Human Rights, the WMA International Code of Medical Ethics, the Declaration on Bioethics and Human Rights, which are the documents that largely determined the current world order. Highlighting the importance of the principle of voluntary informed consent, it is necessary to underline the need for state-level consideration of the bioethics problems. This is the only way to ensure the unity and integrity of state policy and decisions made in this important area, which stretches beyond the scopes of responsibility of individual ministries and departments.

Apparently, US President Bill Clinton followed similar logic when he established the National Bioethics Advisory Commission under his auspices in 1996. In 2001, under US President George W. Bush, the status of the Commission was advanced, its powers expanded. Executive Order 13237 of November 28, 2001 transformed the National Commission into the President's Council on Bioethics. Its members and president, Edmund D. Pellegrino, the famous American scientist and theorist of bioethics, were personally appointed by the President of the United States. The council was supposed to "advise the president on bioethical issues that may arise from advances in biomedical science and technology" [9].

Barack Obama's Order 13521 of November 24, 2009, boosted the status of the body further up and turned it into the Presidential Commission for the Study of Bioethical Issues, which became interdepartmental and received powers, outgrowing its purely philosophical leadership. Amy Gutmann, President of the University of Pennsylvania, was appointed Chairman of the Commission [9]. Shortly thereafter, the information on the Commission's activities became all but inaccessible to the general public, which, according to experts, may indicate the seriousness of the issues discussed and the proposals developed for the President of the United States.

The ethical challenges of the century, having shown the relevance of the lessons of Nuremberg, raised the issues of ethical education of society and ethical assessment of events unfolding in the world. The solution of the problems the society faces is largely associated with the development of bioethics that, in the conditions of the current changing world, is of particular importance to the national security of the Russian state. 


\section{References}

1. Die Nürnberger Prozesse. Sandberg Verlag. Nürnberg. 2008. ISBN 978-3-930699-52-0.

2. Mitscherlich A, Mielke F. Medizin ohne Menschlichkeit: Dokumente des Nürnberger Ärzteprozesses, 16. Aufl., Heidelberg: Fischer 2004. ISBN 978-3-596220-03-8.

3. Pravovye dokumenty. Njurnbergskij kodleks. http://www. psychepravo.ru/law/int/nyurnbergskij-kodeks.htm/Russian.

4. Konstitucija Rossijskoj Federacii, stat'ja 21, chast' 2. http://www. consultant.ru/document/cons_doc_LAW_28399/e7fbd40d5c89 c3066eab2473bcaac30880b58eb3/Russian.

5. Osnovy zakonodatel'stva Rossijskoj Federacii «Ob ohrane zdorov'ja grazhdan». Stat'i 32 i 43. https://rg.ru/1993/08/19/

\section{Литература}

1. Die Nürnberger Prozesse. Sandberg Verlag. Nürnberg. 2008. ISBN 978-3-930699-52-0.

2. Mitscherlich A, Mielke F. Medizin ohne Menschlichkeit: Dokumente des Nürnberger Ärzteprozesses, 16. Aufl., Heidelberg: Fischer 2004. ISBN 978-3-596220-03-8.

3. Правовые документы. Нюрнбергский кодекс. http://www. psychepravo.ru/law/int/nyurnbergskij-kodeks.htm/

4. Конституция Российской Федерации, статья 21, часть 2. http://www.consultant.ru/document/cons_doc_LAW_28399/e7f bd40d5c89c3066eab2473bcaac30880b58eb3/

5. Основы законодательства Российской Федерации «Об охране здоровья граждан». Статьи 32 и 43. https://rg.ru/1993/08/19/ osnovy-zdorovya-dok.html/ osnovy-zdorovya-dok.html/ Russian.

6. Vseobshhaja Deklaracija Prav Cheloveka. https://www.un.org/ru/ documents/decl_conv/declarations/declhr.shtml/Russian.

7. Vseobshhaja deklaracija o biojetike i pravah cheloveka Prinjata rezoljuciej General'noj konferencii JuNESKO 19 oktjabrja 2005 goda. https://www. un.org/ru/documents/decl_conv/declarations/bioethics_and hr.shtml/

8. Guide to Informed Consent Compliance. Washington, USA. Publication date: May 2020. Page count: 705 ISBN-13:978-160430-136-6 https://www.centerwatch.com/products/476-guideto-informed-consent-compliance/

9. Prezidentskij sovet po biojetike SShA. https://ru.qaz.wiki/wiki/ The_President\%27s_Council_on_Bioethics/Russian.

6. Всеобщая Декларация Прав Человека. https://www. un.org/ru/documents/decl_conv/declarations/declhr. shtml/

7. Всеобщая декларация о биоэтике и правах человека Принята резолюцией Генеральной конференции ЮНЕСКО 19 октября 2005 года. https://www.un.org/ru/documents/decl_ conv/declarations/bioethics and hr.shtml/

8. Guide to Informed Consent Compliance. Washington, USA. Publication date: May 2020. Page count: 705 ISBN-13:978-160430-136-6 https://www.centerwatch.com/products/476-guideto-informed-consent-compliance/

9. Президентский совет по биоэтике США. https://ru.qaz.wiki/ wiki/The_President\%27s_Council_on_Bioethics/ 


\title{
RESPECTING PATIENT AUTONOMY: VOLUNTARY INFORMED CONSENT IN MODERN MEDICINE
}

Grebenshchikova EG $\bowtie$, Chuchalin AG

Pirogov Russian National Research Medical University, Moscow, Russia

\begin{abstract}
The article reveals the most influential in modern bioethics approach to understanding voluntary informed consent as a way to implement the principle of respect for patient autonomy, which is determined by both legal regulation and socio-cultural factors. The authors discuss the main elements of informed consent, its specificity in clinical trials, and criteria for autonomous choice.
\end{abstract}

Keywords: informed consent, autonomy, voluntariness, principles of bioethics, clinical research

Author contribution: Research concept and design — Chuchalin AG; text writing and editing — Grebenshchikova EG

$\square$ Correspondence should be addressed: Elena G. Grebenshchikova

Ostrovityanova st. 1, Moscow, 117997; aika45@ya.ru

Received: 12.02.2021 Accepted: 25.03.2021 Published online: 30.03.2021

DOI: 10.24075/medet.2021.001

\section{УВАЖАЯ АВТОНОМИЮ ПАЦИЕНТА: ДОБРОВОЛЬНОЕ ИНФОРМИРОВАННОЕ СОГЛАСИЕ В СОВРЕМЕННОЙ МЕДИЦИНЕ}

\author{
Е. Г. Гребенщикова $\square$, А. Г. Чучалин
}

Российский национальный исследовательский медицинский университет имени Н. И. Пирогова, Москва, Россия

\begin{abstract}
В статье раскрывается наиболее влиятельный в современной биоэтике подход к пониманию добровольного информированного согласия как способа реализации принципа уважения автономии пациента, который обуславливается как нормативно-правовой регламентацией, так и социокультурными факторами. Авторы рассмотривают основные элементы информированного согласия, его специфику в клинических исследованиях и критерии
\end{abstract} автономного выбора.

Ключевые слова: информированное согласие, автономия, добровольность, принципы биоэтики, клинические исследования

Вклад авторов: концепция и дизайн исследования - Чучалин А. Г.; написание и редактирование текста — Гребенщикова Е. Г.

$凶$ Для корреспонденции: Гребенщикова Елена Георгиевна ул. Островитянова, д. 1, г. Москва, 117997; aika45@уa.ru

Статья получена: 12.02.2021 Статья принята к печати: 25.03.2021 Опубликована онлайн: 30.03.2021

DOI: $10.24075 /$ medet.2021.001

In the middle of the last century, the voluntary informed consent $(\mathrm{VIC})$ doctrine emerged against the background of both advancing medical practice and evolving clinical research [1]. The latter was connected with the Nuremberg Code, a document adopted by the international tribunal after completion of the Nuremberg Trials in August 1947, which proposed principles for conducting medical experiments on humans. The first paragraph of the Nuremberg Code reads: "the voluntary consent of the human subject is absolutely essential" [2]. The Code was not legally binding, but became the basis for international and national legislation in many countries. The need for VIC was then enshrined in the World Medical Association's Declaration of Helsinki "Ethical Principles for Medical Research Involving Human Subjects" (1964), which introduced the definition of ethical norms for "non-therapeutic research" (i.e., research pursuing purely scientific purposes) that protect the rights of legally incapacitated persons and persons dependent on the researcher. In medical practice, VIC as an established concept was reflected in numerous patient rights codes: the Patient's Bill of Rights (American Hospital Association, 1972); Lisbon Declaration on the Rights of the Patient (WMA, 1981); Declaration on Promotion of Patients' Rights in Europe (WHO European Office, 1994), etc.

In the 70s of the last century, the need for VIC was established in bioethics, which at that time was actively developing in the United States. In the same period, two main approaches to the problem were shaped in the bioethical literature, ethical-philosophical and legal. The approaches brought to the center of research thought both the legal aspects of failure of inform patients and the responsibility associated therewith, and the moral aspects of re-evaluating relationships in medicine. The doctrine of informing the patient and obtaining consent was theoretically conceptualized in the classic work by T. Beauchamp and J. Childress "Principles of Biomedical Ethics" [3], and then in the studies by other authors. According to T. Beauchamp, autonomous, independent choice and voluntariness are central to the concept of consent $[4,55]$. The independence part is realized through the person's access to the VIC process that allows this person to either authorize the plan suggested by the doctor or reject it. Beauchamp's position is shared by many researchers who argue that it is the ability to choose that fills patient's autonomy with meaning [5].

However, there are two different but interrelated aspects to the answer to the question of association between informed consent and autonomy.

First, the voluntary consent requirement of the Nuremberg Code lacks any explanation referring either to the independence or to the no harm principle ("do no harm") [6]. However, in the 1970s, National Commission for the Protection of Human Subjects of Biomedical and Behavioral Research included research ethics documents in its scope of work and changed the fundamental approach to the matter: it was clearly expressed that the purpose of consent of the research subject is to protect autonomy and personal dignity. The Commission's Belmont Report (1979) argues that "individuals should be treated as autonomous agents," and informed consent underpins respect for the individual, so that "subjects, to the degree that they are capable, be given the opportunity to choose what shall or shall not happen to them" [7]. Subsequently, this approach was established in a number of national and international documents [8]. 
Secondly, many researchers view VIC as an expression of the liberal Western tradition that advocates the importance of individual freedom and choice [9], as reflected in the ethical, philosophical and legal discourses ignited in the US in the second half of the past century. "The values underlying informed consent - autonomy and concern for human wellbeing - are deeply rooted in American culture, in our religious traditions, and in Western moral philosophy. It is not surprising that informed consent is the cornerstone of the current modern medical ethics doctrine and medical law in the United States" [10]. From this perspective, the development of the idea of VIC is viewed as part of the extended social transformations of American healthcare in the second half of the XX century, which saw consolidation of individualistic values in various social spheres. These processes affected the doctor-patient relationship: the doctor's professional authority was no longer indisputable, and the hierarchy in this relationship questioned. The transformation of paternalism was promoted by economic and structural changes that revolutionized the world of medicine, suppression of the "traditional" attitudes in the social spheres (family, church) that were previously unaffected by market values, as well as various civic movements, patient movement included. The VIC doctrine not only reflected these changes but contributed to them. Thus, the concept of patient autonomy has become firmly established in healthcare only in the last decades of the XX century.

\section{Elements of the voluntary informed consent}

The typical VIC elements distinguished in the context of discussions around bioethics are: 1) competence, 2) disclosure of information, 3) understanding, 4) voluntariness and 5) consent [11]. Through this lens, the VIC is seen as follows: a person gives informed consent to an intervention if this person is competent to act, fully informed and understands the information received, voluntarily makes the choice and agrees to the intervention. However, this approach has been criticized. For example, "competence" can be viewed as a necessary prerequisite rather than part of the process of informing and obtaining consent.

T. Beauchamp argues that VIC should be considered mainly in terms of understanding, voluntariness and consent. However, each of these elements should not be absolutized. For example, the level of understanding of the situation depends on education, age and a number of other factors. As shown in the systematic review by J. Flori and E. Emanuel, potential clinical trial participants often do not understand the information disclosed to them in the process of obtaining VIC. Moreover, there is only a few research efforts that consider the ways to improve the level of understanding [12].

At the same time, it is important to understand which choices can be considered autonomous. According to T. Beauchamp and J. Childress, the determining criteria here are as follows: 1) intention; 2) understanding 3) lack of outside influence that can affect the action [13].

\section{Intentional action}

An intentional action must be planned and consistent with the person's idea of it, although the end result may differ from the one expected. T. Beauchamp relies on the intentional action model based on the expression of will and not a desire. Intentional action includes any action and any effect that occur during plan execution. For example, a patient must decide on facial surgery that will leave a scar. The only option is to reject the intervention. Agreeing to the surgery, the patient accepts the scar as a result of the operation. The patient's consent does not mean that this patient would like to be scarred, however, it is as much a personal choice as agreeing to the operation. In many cases, a distinction can be made between intention and intentional action. Thus, "...it can be said that someone intentionally agreed to be scarred during surgery, but has no intention to receive a scar. In other words, an intentional action does not necessarily equal the intention the performer of this action has" [14].

\section{Understanding}

Understanding is the second condition for autonomous action. Understanding forms on the basis of the information necessary to comprehend the essence of the actions and consequences thereof. The latter does not mean thorough analysis of the problem but rather an apprehension of essential facts. However, in some cases, being unaware of at least one fact or misunderstanding some risk can deprive the person of adequate understanding. In addition, understanding may be limited by the person's illness, unwillingness to dialogue with the doctor or other communication problems. A person's inability to perceive information as truthful or objective, even if it is understood adequately, can jeopardize decision-making [lbid.].

\section{Voluntariness}

Voluntariness is the third prerequisite of autonomous action. A person must be free from control exercised either by external agents or by internal conditions that hinder self-government. However, not all influences may be considered controlling. T. Beauchamp focuses on the three types of influence: persuasion, coercion and manipulation. The first is about a rational effort to persuade that is not necessarily about control. By persuading a patient to get tested, the doctor most often wants to influence the behavior of but not control that patient.

Coercion involves force or threats employed to control another human being. For example, when a doctor threatens to discontinue provision of assistance if the patient does not agree to a medical intervention, the doctor seeks to control the patient. Treatment in a psychiatric hospital can be compulsory if the patient is sent there involuntarily. However, submission cannot be considered the result of coercion when someone feels a threat in the actual absence thereof. Coercion can only be acknowledged if a real and deliberate threat violates and alters a person's independent course of action. In case of coercion, even deliberate and well-informed actions can be involuntary.

Manipulation is a form of influence that forces someone to perform an action the agent of influence needs. In healthcare, the most likely forms of manipulation have to do with information. In particular, researchers addressing biomedical problems are often criticized for hiding important information and exaggerating the benefits. Often, overly attractive offers of compensation and healthcare services are also viewed as manipulative.

In this context, it is important to highlight the need to account for not only external influences but also internal factors that limit voluntariness, which can arise from, for example, a mental illness. Thus, in the future, there may arise a question about inviting an authorized person to participate in the process of obtaining informed consent, that person capable of confirming the fact that VIC was signed without external pressure and that the patient understood the essence of the medical intervention, 
and the doctor described the actions to be performed in a sufficiently informative way.

\section{Clinical trials: voluntary informed consent and patient autonomy}

As mentioned above, the Nuremberg Code played a key role in the introduction of VIC to clinical research. However, that did not mean the end of unethical research activities. For example, in 1966, Henry Beecher published an article titled "Ethics and Clinical Research" (New England Journal of Medicine), where he described 22 examples of dubious research experiments none of which had consent obtained from the subjects [15]. Realizing that the journal was read mainly by doctors, he warned the press about the upcoming publication. It ignited intense public debate and led, among other things, to the establishment of the National Commission for the Protection of Human Subjects of Biomedical and Behavioral Research, the first government agency to set bioethics policy in USA.

Another striking and well-known example of a violation of research ethics is the Tuskegee Experiment (Alabama): from 1932 to 1972, researchers studied natural course of syphilis, i.e., patients received no treatment. The study involved 399 black men, 201 of whom were controls. In 1947, there was introduced an effective penicillin-based protocol to treat the disease, but the subjects received neither treatment nor information about it. As a result, over 40 years of the experiment, 28 people died from syphilis, 100 subjects died from the associated complications, 40 wives were infected and 19 children were born with congenital syphilis. The experiment was discontinued in 1972 after a media leak. The outrage that followed led to significant changes in the field of medical research, development of the requirements for informed consent of the subjects, protection of vulnerable persons, ethical committee oversight [16], which were recorded in the Belmont report.

\section{Situations restricting autonomy in clinical trials}

Situations when a subject voluntarily signs informed consent and yet reports forced participation present a complex ethical problem in the context of current clinical trials. The reasons for such collisions are usually associated with unavailability (or limited availability) of medical resources - medicines, diagnostic and therapeutic services, - and research activities being an important source of income. Free checkup or treatment, a monetary reward or stay in the clinic are perceived as offers that cannot be refused. Accordingly, the participant says that "there is no other choice," referring to the circumstances that influence the decision. At the same time, formally, the participant makes the choice freely and voluntarily. In this case, the coercion perceived by the person making the decision is not coercion. Such morally tense situations require special attention in bioethics.

Another ethically controversial issue is the remuneration of clinical trial participants. If the amounts paid meet the expectations and the risks are comparable to everyday risks, the situation is quite clear. However, the incentives generate problems 1) as the risks increase, 2) as more appealing incentives are introduced, 3) as the economic wellbeing of the subjects deteriorates or they lose alternatives or resources [17].

The increasing risks people in difficult financial situations are exposed to can be viewed as leaving them with no other options but to agree to the appealing offers, even if in other circumstances they would have refused. In other words, how a very attractive offer is perceived greatly depends on the risks found in the background. This offer can be manipulative, but not coercive, if it does not contain a threat.

There is another aspect to the moral problem of research subject remuneration: with the over-the-top profits pharmaceutical companies gain, compensations they pay to study participants are small and unfair. The possible solution to these problems is to have the project sponsor pay fair remuneration for participation in moderate risk studies and not increase payments to attract participants to the higher risk studies [18]. Essentially, there should be an approach balancing the two extremes, underpayment and overpayment. It may seem that the simplest way to solve the problem is to completely ban a particular study, or to ban researchers from recruiting subjects from communities where difficult financial circumstances may be viewed as coercive conditions. However, taking into account that the research subjects make their choice independently and voluntarily, albeit with some restrictions, any prohibition in such situations looks morally questionable.

\section{CONCLUSION}

The theory linking VIC-related issues to patient autonomy reflects the dominant, but not the only, approach to the problem found in the scientific literature. Its heuristic potential lies not only in the ability to explicate the evolution of ethical and legal foundations - legal incidents and moral collisions - as prerequisites for reformatting relationships in clinical medicine, where adequate provision of information to the patient underpins autonomous choice, but also to draw attention to a broader sociocultural context. The latter connects transformational processes in medicine with the assertion of values of individualism and self-determination in society. Medicine has been growing more and more technological and digital lately, which intensifies these trends through expansion of the patient's awareness, fostering the desire to actively monitor health indicators with the help of health trackers and self-diagnostics devices. Therefore, it is now necessary to take into account the new contexts of the rapidly developing e-healthcare. While telemedicine entailed procedures designed to obtain VIC remotely, advances in genetics and biobanking call for rethinking of both the information component and the way in which consent is obtained for each study, as genetic data is reusable. Thus, adequate responses to the challenges posed by new biomedical technologies, as well as improvement of the doctor-patient relationship, require further interdisciplinary research addressing $\mathrm{VIC}$ theory and practice of its application in current medicine.

\section{References}

1. Dankar FK, Gergely M, Dankar SK. Informed consent in biomedical research. Computational and structural biotechnology journal. 2019; 17: 464.
2. Nuremberg Code. http://www.psychepravo.ru/law/int/nyurnbergskijkodeks.htm. Russian.

3. Beauchamp TL, Childress JF. Principles of Biomedical Ethics. 
Oxford University Press. 2001; 454 p.

4. Beauchamp TL. Autonomy and consent. In book: The ethics of consent: theory and practice. Oxford University Press, 2010; 55 p.

5. Naik AD, Dyer CB, Kunik ME, McCullough, L. B. Patient autonomy for the management of chronic conditions: A two-component reconceptualization. The American journal of Bioethics. 2009; 9 (2): 23-30

6. Beauchamp TL. Autonomy and consent. In book: The ethics of consent: theory and practice. Oxford University Press. 2010; 58-61 p.

7. The Belmont Report. Ethical principles and guidelines for the protection of human subjects of research on April 18, 1979. http://www.bioethics.ru/rus/library/id/388/. Russian.

8. Brady JV, Jonsen AR. The evolution of regulatory influences on research with human subjects. In book: Human subjects research. Springer, Boston, MA, 1982; 3-18 p.

9. Dolgin JL. The legal development of the informed consent doctrine: past and present. Cambridge Q. Healthcare Ethics. 2010; 19 (1): 97-109.

10. Berg JW. et al. Informed consent: legal theory and clinical practice.

\section{Литература}

1. Dankar FK, Gergely M, Dankar SK. Informed consent in biomedical research. Computational and structural biotechnology journal. 2019; 17: 464.

2. Нюрнбергский кодекс. http://www.psychepravo.ru/law/int/ nyurnbergskij-kodeks.htm

3. Beauchamp TL, Childress JF. Principles of Biomedical Ethics. Oxford University Press. 2001; 454 p.

4. Beauchamp TL. Autonomy and consent. In book: The ethics of consent: theory and practice. Oxford University Press, 2010; 55 p.

5. Naik AD, Dyer CB, Kunik ME, McCullough, L. B. Patient autonomy for the management of chronic conditions: A two-component reconceptualization. The American journal of Bioethics. 2009; 9 (2): 23-30

6. Beauchamp TL. Autonomy and consent. In book: The ethics of consent: theory and practice. Oxford University Press. 2010; 58-61 p.

7. Бельмонтский доклад. Этические принципы и рекомендации по защите человека при проведении исследований 18 апреля 1979 г. http://www.bioethics.ru/rus/library/id/388/

8. Brady JV, Jonsen AR. The evolution of regulatory influences on research with human subjects. In book: Human subjects research. Springer, Boston, MA, 1982; 3-18 p.

9. Dolgin JL. The legal development of the informed consent
Oxford University Press. 2001; 14 p.

11. Beauchamp TL. Autonomy and consent. In book: The ethics of consent: theory and practice. Oxford University Press, 2010; 56 p.

12. Flory J, Emanuel E. Interventions to improve research participants understanding in informed consent for research: a systematic review. Jama. 2004; 292 (13): 1593-1601.

13. Beauchamp TL, Childress JF. Principles of Biomedical Ethics. Oxford University Press, 2001; 454 p.

14. Beauchamp TL. Autonomy and consent. In book: The ethics of consent: theory and practice. Oxford University Press. 2010; 68 p.

15. Beecher HK. Ethics and clinical research. N Engl J Med. 1966; 274 (24): 1354-1360 .

16. Reverby SM. Examining Tuskegee: The infamous syphilis study and its legacy. - Univ of North Carolina Press, 2009; 384 p.

17. Faden RR, Beauchamp TL. A history and theory of informed consent. Oxford University Press. 1986; 392 p.

18. Schonfeld TL. et al. Research involving the homeless: arguments against payment-in-kind (PinK) //IRB: Ethics \& Human Research. 2003; 25 (5): 17-20.

doctrine: past and present. Cambridge Q. Healthcare Ethics. 2010; 19 (1): 97-109.

10. Berg JW. et al. Informed consent: legal theory and clinical practice. Oxford University Press. 2001; 14 p.

11. Beauchamp TL. Autonomy and consent. In book: The ethics of consent: theory and practice. Oxford University Press, 2010; 56 p.

12. Flory J., Emanuel E. Interventions to improve research participants understanding in informed consent for research: a systematic review. Jama. 2004; 292 (13): 1593-1601.

13. Beauchamp TL, Childress JF. Principles of Biomedical Ethics. Oxford University Press, 2001; $454 \mathrm{p}$

14. Beauchamp TL. Autonomy and consent. In book: The ethics of consent: theory and practice. Oxford University Press. 2010; 68 p.

15. Beecher HK. Ethics and clinical research. N Engl J Med. 1966; 274 (24): 1354-1360.

16. Reverby SM. Examining Tuskegee: The infamous syphilis study and its legacy. - Univ of North Carolina Press, 2009; 384 p.

17. Faden RR, Beauchamp TL. A history and theory of informed consent. Oxford University Press. 1986; 392 p.

18. Schonfeld TL. et al. Research involving the homeless: arguments against payment-in-kind (PinK) //IRB: Ethics \& Human Research. 2003; 25 (5): 17-20. 


\title{
AWARENESS AS A CRITERION OF LEGALITY OF OBTAINING THE PATIENT'S CONSENT TO MEDICAL INTERVENTION
}

Pishchita AN $\bowtie$, Alekseev VA, Borisov KN

Russian Medical Academy of Continuing Professional Education of the Ministry of Health of the Russian Federation, Moscow, Russia.

\begin{abstract}
The doctrine of patient consent to medical intervention, as a compulsory procedure, emerged in the forties of the twentieth century. However, up until the present the problem of obtaining patient consent cannot be considered conclusively resolved. One of the intervention legality criteria is the patient's complete (sufficient) awareness of the proposed medical intervention.
\end{abstract}

Keywords: patient rights, informed voluntary consent of the patient, medical intervention, right to personal integrity, patient awareness, complete (sufficient) information, duties of medical professionals.

Author contribution: Pishchita AN, Alekseev VA — contribution to the concept, analysis of legislation, Borisov KN — contribution to the concept, editing.

$\checkmark$ Correspondence should be addressed: Alexander N. Pishchita

Barrikadnaya st., 2/1, b. 1, Moscow; alexpischita@mail.ru

Received: 26.02.2021 Accepted: 26.03.2021 Published online: 30.03.2021

DOI: $10.24075 /$ medet.2021.006

\section{ИНФОРМИРОВАННОСТЬ КАК КРИТЕРИЙ ЗАКОННОСТИ ПОЛУЧЕНИЯ СОГЛАСИЯ ПАЦИЕНТА НА МЕДИЦИНСКОЕ ВМЕШАТЕЛЬСТВО}

\author{
А. Н. Пищита $\bowtie$, В. А. Алексеев, К. Н. Борисов
}

Российская медицинская академия непрерывного профессионального образования Министерства здравоохранения Российской Федерации, Москва, Россия

Доктрина обязательного получения согласия пациента на медицинское вмешательство возникла в сороковые годы двадцатого века, однако, до сих пор проблему регламента получения согласия пациента нельзя отнести к категории окончательно решенной. Одним из критериев легитимности выполнения вмешательства является полная (достаточная) информированность пациента о предлагаемом медицинском вмешательстве, рисках и осложнениях при его выполнении. Кроме того, расширение прав граждан, получающих медицинскую помощь, в рамах Федерального закона от 21 ноября 2011 г. N 323-Ф3 “Об основах охраны здоровья граждан в Российской Федерации», а так же распространение норм федеральных законов, защищающих права граждан, как потребителей услуг и работ, на пациентов существенно повышает требования к работе медицинских работников, в обязанности которых входит неукоснительное соблюдение прав пациентов.

Ключевые слова: права пациента, информированное добровольное согласие пациента, медицинское вмешательство, право на личную неприкосновенность, информированность пациента, полная (достаточная) информация, обязанности медицинских работников.

Вклад авторов: Пищита А. Н., Алексеев В. А. — вклад в концепцию, анализ законодательства, Борисов К. Н. — вклад в концепцию, редактирование.

Для корреспонденции: Пищита Александр Николаевич

ул. Баррикадная, д. 2/1, стр. 1, г. Москва, 125993; alexpischita@mail.ru

Статья получена: 26.02.2021 Статья принята к печати: 26.03.2021 Опубликована онлайн: 30.03.2021

DOI: 10.24075/medet.2021.006

Awareness is one of the fundamental criteria backing the patient's right to give or refuse consent to medical intervention. The legal requirement to inform the patient primarily covers the following:

- risks of unfavorable development of the disease (condition) in case the patient refuses medical intervention;

- risks of development of complications associated with the medical intervention necessitated by the patient's condition (disease).

It is awareness that allows the patient to compare the risks of adverse development of the disease and the probable (described in the literature) complications associated with the intervention that may arise both during such an intervention, immediately thereafter or later.

The first document to formalize the basic principles of sufficient awareness of a person participating in the study was the Nuremberg Code of 1947, the international code governing human experiments. The code states that a study participant should have sufficient knowledge and understand the essence of the information presented, these knowledge and understanding enabling the participant to make the participation decision while clearly seeing the purpose of the research effort and the associated risks the participants are exposed to.

Before being asked for a well-informed decision, the candidate participant should receive information about:
- duration and purpose of the study;

- means and methods applied;

- the expected inconveniences and probable harm to the participant's health associated with the study;

- negative consequences for the participant's mental and physical health that can, with a certain degree of probability, be a result of participation in the experiment.

After the Nuremberg trials, the concept of "informed consent" is systematically used in European and US courts in the context of medical malpractice cases involving compensation for harm caused through inappropriate provision of medical care.

Around 1950s, the information doctors provided to the patients was of a purely professional (medical) nature, but in the 1970s, there was introduced the patient-oriented approach, which prescribed presenting information in the form the patient can comprehend, with the mandatory components thereof as follows:

- treatment purpose description,

- possible risks,

- existing alternative treatments.

Subsequently, the provisions of the first clause of the Nuremberg Code, which determine the amount and nature of information mandatorily provided to a candidate study participant, were substantially extended. They found 
application not only in the context of lawsuits pertaining to harm caused in the course of clinical trials, but also in litigations about compensations for harm caused through improper provision of medical care.

In 1997, Article 5 of the Convention on Human Rights and Biomedicine stipulated that not only clinical trials, but also medical interventions require free, awareness-based informed consent given by the person offered such interventions.

Upfront, such a person should be provided with appropriate information about the purpose and nature of the proposed intervention, its possible consequences and risks associated therewith [1].

In Russia, the doctor's duty to obtain "the patient's consent" was first formalized on December 1, 1924, when the National Central Executive Committee and the Council of People's Commissars of the RSFSR enacted the Decree "On professional activity and rights of medical workers" [2]. However, this document required obtaining consent only before surgery. Declaration of the Rights and Freedoms of Man and Citizen adopted by the Supreme Soviet of the RSFSR in 1991, the Constitution of the Russian Federation, Fundamentals of the Legislation of the Russian Federation on Health Protection, the Russian Federation Law "On Transplantation", the Russian Federation Law "On psychiatric care and citizen rights guarantees in the context of its provision", as well as a number of other legislative acts adopted in the 1990s, have significantly expanded the personal inviolability rights of citizens (including personal information protection rights) in the context of applying for medical assistance, including:

- the right to informed voluntary consent to medical intervention (Article 32 of the Fundamentals of the Legislation of the Russian Federation on Health Protection);

- the right to refuse medical intervention (Article 33 of the Fundamentals of the Legislation of the Russian Federation on Health Protection);

- the right to receive information about the person's health in an accessible form, including information about examination results, presence of the disease, diagnosis and prognosis, treatment methods, the associated risk, medical intervention options, consequences thereof and treatment results (Article 31 of the Fundamentals of the Legislation of the Russian Federation on Health Protection) [3].

The definition of the "patient's informed voluntary consent" was adopted in the Russian legislation for the first time ever. This definition reflects the patient's right to make an independent, awareness-based decision to give consent or refuse medical intervention.

The Federal Law 323-FZ "On Basics of Health Protection of the Citizens in the Russian Federation" (passed in 2011) entitles the patient to receive full information from a medical professional, this information enabling the patient to make a decision on granting consent to the proposed medical intervention.

Although the definition of "informed voluntary consent" has not changed, it is only since 2012 that people seeking medical assistance at medical institutions have the right to make a decision on allowing a medical intervention once they are in possession of all the relevant information.

Any medical intervention that affects physical, mental, social components of a person's life can take place only after the person such intervention is offered to gives free, informed consent for this specific certain medical intervention.

There is an innovation in the legislative regulation of realization of the citizens' right to personal inviolability in the context of medical care: on the one hand, the law entitles the patient to all the information a medical institution has about health (diseases, complications) of this person;

on the other hand, the law obligates medical workers to fully inform the patient deciding whether to consent to or refuse medical intervention, the information provided enabling the patient to make the important decision.

Following is the review of the order observed by the subjects of medical relations (legal aspects thereof) as they exercise their duly formalized rights and fulfill obligations having to do with the need to provide information to the patient before obtaining his/ her consent to the medical intervention.

Article 20 of the Federal Law "On Basics of Health Protection of the Citizens in the Russian Federation" lists the information that a medical professional must provide to a patient before obtaining his/her consent to medical intervention.

The informed voluntary consent of a citizen is a necessary prerequisite for medical intervention. The consent can be given by the patient personally or by his/her legal representative; the decision relies on the information provided by the medical professional (in full and in an accessible form):

- about the goals, methods of provision of medical assistance, the associated risk,

- about the possible medical intervention options, consequences thereof, and

- about the expected results of medical assistance [4].

Besides, the patient is entitled to get the following information from the medical institution in the comprehensible form:

- about the state of his/her health, including information about the results of a medical examination, presence of the disease, diagnosis and prognosis,

- about the methods of provision of medical assistance, the associated risk,

- about the possible medical intervention types, consequences thereof, and

- about the results of medical assistance [5].

A medical institution, represented by the attending physician, is also obliged to:

- inform citizens about the possibility of receiving medical care under the state program guaranteeing free provision of medical care to citizens and territorial state-guaranteed programs stipulating free medical assistance to citizens;

- provide patients with reliable information about the medical care provided, the effectiveness of treatment methods, drugs and medical devices used;

- using communication patterns/channels accessible to the citizenry, including websites, inform people about medical activities and medical professionals, level of their education and qualifications, as well as provide other necessary information as prescribed by the rulings of the authorized federal executive body;

- inform patients of the order of gratuitous provision of medical assistance as guaranteed by the state program, the scope thereof and conditions applicable thereto [6].

In addition, the attending physician, when recommending the patient a drug, a medical device, foods for special medical purposes or a breast milk substitute, shall inform the patient about how he/she can obtain such a drug, medical device, foods for special medical purposes or a breast milk substitute free of charge, as per provisions of the legislation of the Russian Federation [7]. Apart from Federal Law 323, there are other federal regulations that govern medical professionals' responsibility to provide patients with information. In particular, there are consumer protection laws that apply to the cases of provision of medical assistance by medical institutions under voluntary and compulsory health insurance policies [8]. 
Article 8 of the Russian Federation Law "On Protection of Consumer Rights" entitles the consumer's (patient's) right "to request provision of the necessary and reliable information about the manufacturer (executor, seller), its work pattern and the goods (works, services) sold [9]", and Article 9 of this Law clearly obligates the manufacturer (executor, seller), upon consumer's request, to provide clear information about itself and the maker (seller) (company name, location (address), work pattern, legal entity state registration number, last name, first name, patronymic (if any), private entrepreneur state registration number) [10].

Since medical services are licensed and medical professionals rendering such should be accredited by the state, under the said law the consumer (patient) must be informed of the type of activity of the manufacturer (executor, seller), the license number and (or) the number of the state accreditation certificate, the duration of this license and (or) certificate, and provided information on the body that issued this license and (or) certificate [11].

Under the Law, the above information shall mandatorily be provided to the consumer of medical services (patient) even if such services are provided outside the permanent location of the medical services provider (at home, in a factory, outdoors and in other conditions) [12].

The medical services provider (medical professional), mandatorily and in a timely manner, provides the consumer (patient) with the necessary and reliable information about the goods (works, services) that enables correct selection of such goods (works, services) [13]

The Law also lists pieces of information that should be conveyed to the patient as consumer of the medical services:

- information about the main consumer properties of goods (works, services);

- information about contraindications relevant in the presence of certain diseases;

- the price in rubles and the goods (work, services) purchase conditions, including post-payment situations, when the goods (work, services) are paid for after a certain time following their transfer (performance, provision) to the consumer, and the full amount payable by the consumer, as well as the payment schedule covering this amount;

- warranty period, if any;

- rules and conditions ensuring effective and safe use of the goods (works, services);

- service life or shelf life of the goods (works), as established by the Russian Federation Law "On Protection of Consumer Rights";

- information about the actions the consumer needs to take once the specified periods are over, and the possible consequences of refusal to take such actions in case the goods (work), when expired, are dangerous for life, health and property of the consumer or become unsuitable for use as intended;

- address (location), company name of the manufacturer (executor, seller), authorized organization or authorized private entrepreneur, importer;

- mandatory confirmation of the conformity of goods (works, services) specified in paragraph 4 of Article 7 of the Russian Federation Law "On Protection of Consumer Rights";

- rules of sale of goods (execution of work, provision of services);

- clear indication of a specific person who will perform the work (provide a service), and information about this person, if it is relevant from the point of view of the nature of work (service) [14].
The Law holds the executor (medical organization) responsible for provision of inappropriate information about the work and/or service offered to the patient.

A medical organization, as a service provider that did not give the patient complete and reliable information about the medical procedure/treatment, is responsible for the faults associated with the said service (work) manifesting after its completion and resulting from the patient not being provided the reliable information in full.

Having discovered deficiencies in the results of the service provided (work performed), the patient has the legal right, at his/her discretion, to demand from the medical organization:

1) gratuitous elimination of the said deficiencies, including complications arising during or after medical intervention;

2) an appropriate price reduction, if the medical service (work) is rendered (performed) for a fee;

3) gratuitous fabrication of another item (for example, a denture) from the same material and of the same quality, or refabrication. In this case, the consumer (patient) shall return the item previously transferred to him/her by the provider;

4) reimbursement of the costs the patient incurred to eliminate the faults of the provided medical service (work performed), such elimination done himself/herself at his/her own expense or with the help of third parties at their expense.

Under Article 29 of the aforementioned Law, a patient, as a consumer, has the right to claim compensation for poor results of both the work performed and the services rendered. This is not an exhaustive list of information a medical professional should provide to a patient before obtaining consent to medical intervention.

Current legislation of the Russian Federation assumes administrative, civil, and criminal liability for medical professionals (medical organizations) if they fail to provide the patient, as a consumer of services, with sufficient, reliable, complete information about the service offered.

Federal Laws lack clear definitions of characteristics of information (complete, sufficient, reliable), which makes conforming to such requirements problematic and enables some patients, i.e., consumers of medical services, to abuse their rights.

\section{CONCLUSIONS}

1. The terms used in federal regulations, i.e., "complete, reliable, sufficient information", do not have clear legal definitions.

2. The vagueness of the list of pieces of information that must be provided to the patient prior to the registration of his/ her consent to medical intervention, such consent relying on complete awareness, creates difficulties in the exercising of the patient's right to personal integrity.

3. It is necessary to legislate the list of pieces of information that medical professionals are obliged to provide to the patient in order to obtain his/her consent based on sufficient and reliable information, relying on the current legislation of the Russian Federation, as applied to court cases of violation of patients' rights in the context of provision of medical services under voluntary and compulsory health insurance policies.

4. Clear legislation that would regulate obtaining patient's consent to medical intervention will enable full realization of the patients' right to personal integrity and also help avoid holding medical professionals (medical organizations) legally liable on formal grounds, in cases not involving harm to the health and life of the patient. 


\section{References}

1. Kartashkin VA, Lukasheva EA. Konvencija o zashhite prav cheloveka i dostoinstva chelovecheskogo sushhestva $\vee$ svjazi $\mathrm{s}$ ispol'zovaniem dostizhenij biologii i mediciny: konvencija o pravah cheloveka i biomedicine. (Ov'edo, 4 aprelja 1997 g.). Mezhdunarodnye akty o pravah cheloveka: Sbornik dokumentov. Izd. NORMA, M., 2002; 742 s. Russian.

2. Dekret VCIK i SNK RSFSR «O professional'noj rabote i pravah medicinskih rabotnikov». Sobr. Uzakonenij i Rasporjazhenij RKP. 1924; 88: 892. Russian.

3. Pishchita AN. Soglasie na medicinskoe vmeshatel'stvo. Medikopravovoj analiz. Juridicheskie standarty. Praktika realizacii. M.: CKB RAN; 2006; 19 s. Russian.

4. Chast' 1 stat'i 20 Federal'nogo zakona ot 21 nojabrja $2011 \mathrm{~g}$. N 323-FZ «Ob osnovah ohrany zdorov'ja grazhdan v Rossijskoj Federacii». SPS «GARANT». Russian.

5. Chast' 1 stat'i 22 Federal'nogo zakona ot 21 nojabrja $2011 \mathrm{~g}$. N 323-FZ «Ob osnovah ohrany zdorov'ja grazhdan v Rossijskoj Federacii». SPS «GARANT». Russian.

6. Stat'ja 79 Federal'nogo zakona ot 21 nojabrja 2011 g. N 323-FZ «Ob osnovah ohrany zdorov'ja grazhdan v Rossijskoj Federacii».

\section{Литература}

1. Карташкин В.А., Лукашева Е.А. Конвенция о защите прав человека и достоинства человеческого существа в связи с использованием достижений биологии и медицины: конвенция о правах человека и биомедицине. (Овьедо, 4 апреля 1997 г.). Международные акты о правах человека: Сборник документов. Изд. НОРМА, М., 2002; 742 с.

2. Декрет ВЦИК и СНК РСФСР «О профессиональной работе и правах медицинских работников». Собр. Узаконений и Распоряжений РКП. 1924; 88: 892.

3. Пищита А.Н. Согласие на медицинское вмешательство. Медико-правовой анализ. Юридические стандарты. Практика реализации. М.: ЦКБ РАН; 2006; 19 с.

4. Часть 1 статьи 20 Федерального закона от 21 ноября 2011 г. N 323-Ф3 «Об основах охраны здоровья граждан в Российской Федерации». СПС «ГАРАНТ».

5. Часть 1 статьи 22 Федерального закона от 21 ноября 2011 г. N 323-Ф3 «Об основах охраны здоровья граждан в Российской Федерации». СПС «ГАРАНТ»

6. Статья 79 Федерального закона от 21 ноября 2011 г. N 323Ф3 «Об основах охраны здоровья граждан в Российской
SPS «GARANT». Russian.

7. Chast' 4 stat'i 70 Federal'nogo zakona ot 21 nojabrja $2011 \mathrm{~g}$ N 323-FZ «Ob osnovah ohrany zdorov'ja grazhdan v Rossijskoj Federaciï. SPS «GARANT». Russian.

8. Postanovlenie Plenuma Verhovnogo Suda Rossijskoj Federacil ot 28 ijunja $2012 \mathrm{~g}$. N $17 \mathrm{~g}$. Moskva «O rassmotrenii sudami grazhdanskih del po sporam o zashhite prav potrebitelej». SPS "GARANT». Russian.

9. Chast' 1 stat'i 8 Zakona RF ot 7 fevralja 1992 g. N 2300-I «O zashhite prav potrebitelej». SPS «GARANT». Russian.

10. Chast' 1.1. stat'i 8 Zakona RF ot 7 fevralja 1992 g. N 2300-I «O zashhite prav potrebitelej». SPS «GARANT». Russian.

11. Chast' 2 stat'i 9 Zakona RF ot 7 fevralja 1992 g. N 2300-I «O zashhite prav potrebitelej». SPS «GARANT». Russian.

12. Chast' 3 stat'i 9 Zakona RF ot 7 fevralja 1992 g. N 2300-I «O zashhite prav potrebitelej». SPS «GARANT». Russian.

13. Chast' 1 stat'i 10 Zakona RF ot 7 fevralja 1992 g. N 2300-I «O zashhite prav potrebitelej». SPS «GARANT». Russian.

14. Chast' 2 stat'i 10 Zakona RF ot 7 fevralja 1992 g. N 2300-I «O zashhite prav potrebitelej». SPS «GARANT». Russian.

Федерации». СПС «ГАРАНТ».

7. Часть 4 статьи 70 Федерального закона от 21 ноября 2011 г. N 323-Ф3 «Об основах охраны здоровья граждан в Российской Федерации». СПС «ГАРАНТ».

8. Постановление Пленума Верховного Суда Российской Федерации от 28 июня 2012 г. N 17 г. Москва «O рассмотрении судами гражданских дел по спорам о защите прав потребителей». СПС «ГАРАНТ».

9. Часть 1 статьи 8 Закона РФ от 7 февраля 1992 г. N 2300-I «O защите прав потребителей». СПС «ГАРАНТ».

10. Часть 1.1. статьи 8 Закона РФ от 7 февраля 1992 г. N 2300-І «О защите прав потребителей». СПС «ГАРАНТ».

11. Часть 2 статьи 9 Закона РФ от 7 февраля 1992 г. N 2300-I «О защите прав потребителей». СПС «ГАРАНТ».

12. Ч Часть 3 статьи 9 Закона РФ от 7 февраля 1992 г. N 2300-I «О защите прав потребителей». СПС «ГАРАНТ».

13. Часть 1 статьи 10 Закона РФ от 7 февраля 1992 г. N 2300-I «О защите прав потребителей». СПС «ГАРАНТ».

14. Часть 2 статьи 10 Закона РФ от 7 февраля 1992 г. N 2300-I «O защите прав потребителей». СПС «ГАРАНТ». 


\title{
THE INHERENT RIGHT TO MAKE A MISTAKE (ON INFORMED CONSENT)
}

\section{Zorin NA $\otimes$}

Russian Society for Evidence Based Medicine, Moscow, Russia

\begin{abstract}
The Informed Consent (IC) procedure is considered as a legal construct, a product of liberal economics. As such, IC is a tool for shifting responsibility for the choice of intervention from the seller of health care services to the consumer and is a binding contract to avoid legal liability and all sorts of losses on both sides. The set of problems surrounding the IC can be explained by the significant difference between an experimental procedure (for which it was originally created) and everyday clinical practice. The application of the IC law has no mechanisms for its individual application because it fails to take into account the psychology of decision-making. Keywords: bioethics, informed consent, industrial development of medicine, liberal economics, psychology of decision-making.
\end{abstract}

Keywords: bioethics, voluntary informed consent (VIC), industrial development of medicine, liberal economics, decision-making psychology

$\triangle$ Correspondence should be addressed: Nikita A. Zorin

Dmitrovskoe highway, 46, b. 2, of. 17, Moscow, 127238; nzorin@inbox.ru

Received: 16.03.2021 Accepted: 26.03.2021 Published online: 29.03.2021

DOI: 10.24075/medet.2021.004

\section{НЕОТЪЕМЛЕМОЕ ПРАВО СОВЕРШИТЬ ОШИБКУ (ОБ ИНФОРМИРОВАННОМ СОГЛАСИИ)}

\author{
Н. А. Зорин $\bowtie$ \\ Общество специалистов доказательной медицины (ОсДМ), г. Москва, Россия
}

\begin{abstract}
Рассматривается процедура добровольного информированного согласия (ДИС), как правовая конструкция, продукт либеральной экономики. В этом качестве ДИС является инструментом перекладывания ответственности за выбор вмешательства с продавца медицинских услуг на потребителя и является контрактным договором, позволяющим избежать судебной ответственности и всевозможных потерь с обеих сторон. Комплекс проблем вокруг ДИС можно объяснить существенным различием ситуации эксперимента (для которой оно создавалось первоначально) и повседневной клинической практики. Закон о ДИС не имеет механизмов индивидуального применения, ибо не учитывает вопросов психологии принятия решений.
\end{abstract}

Ключевые слова: биоэтика, добровольное информированное согласие (ДиС), индустриальное развитие медицины, либеральная экономика, психология принятия решений

$\triangle$ Для корреспонденции: Зорин Никита Александрович

Дмитровское шоссе, д 46 к 2, оф 17, г Москва, 127238; nzorin@inbox.ru

Статья получена: 16.03.2021 Статья принята к печати: 26.03.2021 Опубликована онлайн: 29.03.2021

DOI: $10.24075 /$ medet.2021.004

"...Securing agreement on general claims (like "respect human beings") is easy but securing agreement on the meaning of these claims is not".

Xavier Symons [1]

\section{Background $^{1}$}

The informed consent (IC) is justly regarded as an achievement in social development that has been established during transition from "medical" to "social" model of medicine. PD Tishhenko writes the following: "In the space, open to the public eye, the idea of human rights as the attribute of individual's unique personality and citizenship is beginning to dominate, the implementation of which in biomedicine shows up in the fact, that the main principle concerning the doctor-patient relationship is the principle of voluntary informed consent. Moreover, this concerns both scientific research and daily medical practice" [2]. However, the further development has demonstrated significant differences between the experimental procedure (for which the subjects' IC was originally created and used $)^{2}$ and the daily clinical practice, whereas there has been no substantive change in $\mathrm{IC}^{3}$.

A notable difference between the subject's "problem of choice" and the patient's choice is the fact that the choice of participation/non-participation (in the experiment) is joined by the treatment option selection, which is most commonly the selection not between two options, but between multiple options. Moreover, the patient is cornered by the disease; refusal to make a decision or fear of "bad decision" inevitably gives rise to the feeling of guilt and does not contribute to recovery. This distinction was the reason for mutual irritation of physicians and patients (specifically in Russia). They started living in a world, where the statement "What gave you the right to tell me about it?", attributed to Z. Freud, who was told by his physician that he had cancer, was replaced by the nearly forcible knowledge about the disorder ${ }^{4}$. After all, biopower (M. Foucault) then "took the form of caring about the quality of human life, its health and effectiveness" [2].

Where does the conflict come from? This would be the focus of our report.

\section{Ethics and market economy}

Apparently, the Nuremberg Code moral and legal standards, just like the subsequent Declaration of Helsinki, that gave rise to contemporary IC used in daily clinical practice, were successfully seized by the Market, and IC was absorbed in the industrial, market-oriented, and economic environment serving the interests of those.

IC has nothing to do with medicine. It is a legal construct, the product of market economy that includes medicine as a health care services production industry. It is a product of a contractual arrangement between the seller and the consumer 
of services, and, in many ways, a consequence of judicial precedents. At times of complete and utter mind games, overwhelming mutual blackmail and clarification of claims in court, the existence of $\mathrm{IC}$ is reasonable and necessary.

The objective of IC is to allow both parties to avoid judicial responsibility and to deter all kinds of losses. The origin of IC is market (economy). IC is a legal structure. This is indirectly confirmed by the fact, that the ideas of IC are actively promoted either by non-physicians, or by those, who have not requested any consent from the patient for a long time... The mechanism for IC creation is convention, the process agreement "sanctified" by the actions making it lawful: for example, by "internationality" (i.e., the global segregation), and "collectivization" of guilt and liability.

Everything else (discussions about "rights", "freedom", etc.) has turned into political and ideological "noise", which allows a certain range of people to use the listed mechanisms to control the actions of others [3]. In her article "How Neoliberalism Is Damaging Your Mental Health", Ruth Cain (lecturer in law, University of Kent) tells of "an economy of non-stop distraction, in which attention is repeatedly grabbed at and financially exploited" [4].

There are various mechanisms of finger-pointing and shifting the responsibility as a form of protection against judicial responsibility (consequences of harsh actions, accidents and occasions) both in medicine and in other areas related to contractual arrangements:

- IC

- Conflict of interest disclosure

- Assisted suicide ("risk mutualization")

- Writing prescription containing just the international nonproprietary name (the patient can select an affordable drug)

- Warning about potential health hazard of harmful addictions (smoking, alcohol consumption, etc.)

- Warning about unacceptability of certain actions (about washing a dog in a washing machine, drying a cat in a microwave, the possibility to burn one's hands with hot coffee in a paper cup, and other "instructions for imbecile"; almost all of them result from judicial precedents) [5].

These mechanisms work even in the realm of outright fraud: after his release from prison, SP Mavrodi gave us a "groundbreaking" warning: "Be careful! It's a pyramid scheme!"... I.e., he gave a clear warning, telling the public he was a thief! And then? And then it's our fault that we have agreed to participate after such a warning... [ibid.]

The closest thing to $\mathrm{IC}$ is the customer's decision to purchase or not to purchase a product after the seller has told him straight all the pros and cons of the product.

Therefore, the majority of Russian physicians do not like the IC requirements. These destroy the physician's identity. The physician ceases to be "hippocratic": the one, who has been formerly responsible for intervention decision making, becomes a service worker. Ultimately, the physician cares only about the stakeholders' signatures on the IC agreement.

The concept of having "a right to be informed" is put above the concept of benefit and harm. The patient has a right to make a wrong choice (not to choose, as it is called, the most optimal option), and the physician has to bend before this right contrary to his original intent (to "nonmaleficence" and other "old-fashioned" virtues of classical medicine)... Unless the patient selects the "option" not to be informed, prohibition to push the patient for decision paradoxically deprives the physician his right to give a qualified advice, and forces the physician to play sort of a game with the patient, similar to "yes and no not to speak", "black and white not to take...".

The liberal colleague writes the following: "When informing the patient, we have to consider the fact that it is not us who make a treatment decision, but the patient. Moreover, it is extremely important to keep in mind that the decision to be treated or not to be treated, as well as the treatment option selection, is not at all a medical decision" [6].

In terms of classical medicine, it sounds like sacrilege. All right, the patient's decision to be treated/not to be treated is really not a medical decision ${ }^{5}$. However, why do we consider the decision non-medical when shifting the responsibility to select the treatment option onto patient? Because shifting the responsibility to make a medical decision onto incompetent person requires "legal cleanup" to avoid judicial responsibility for such shifting. And then the treatment method (!) becomes the "non-medical" issue.

Within the bounds of "old-fashioned" classical "hippocratic" medicine, the principles of which are being taught at the medical higher education institutions by inertia along with the IC principles, shifting the responsibility onto patient is considered immoral. There is a "cognitive dissonance". Therefore, the opposite process aimed at removing the conflict is going on. The "tenets" of classical medicine (Hippocratic Oath, etc.) are revised, rethought and destroyed in a logical manner, being considered as outdated [7], [8].

The concept of morality is also being revised; it can transform into its opposite in accordance with economic viability. It is something like the Xth revision of Ten Commandments [3].

The Sicily statement for some reason firmly tied "the round and the sour", and namely IC and evidence-based medicine (EBM). The statement stipulates: "Decisions should be made by those receiving care, informed by the tacit and explicit knowledge of those providing care, within the context of available resources» [9]. This link (IC=EBM) appears to be a discouraging political chicanery, very much like the link between homophobia and fascism. This paralyzes any criticism. Who wants to be perceived as being a retrograde or a rascal?

In the context of modern economic liberalism of medicine the responsibility not only of the intervention selection, but also of his health, has been shifted onto patient under the pretext of Freedom (Free will). "Neoliberalised healthcare requires every patient $<\ldots . .>$ to take responsibility for her own state or behaviour. $<\ldots>$ Neoliberal states divest themselves of the costs of care by individualising and privatising care duties. People displaying troubling symptoms are divided into the "dangerous", against whom punitive or authoritarian containment methods may be used, and those left to cope with what resources they or their families have left" [4].

\footnotetext{
${ }^{1}$ All the emphasis marks to the text are made by me, NZ, unless explicitly stated otherwise.

2 "First of all, the subject informed consent is essential, which means that the person engaged in the experiment has a legitimate right to give such consent and is free to choose, without any violence, deception, fraud, trickery, or any other forms of covert coercion; has adequate knowlege allowing him/her to grasp the experimental concept and to make an informed decision. The latter requires the subject to be informed about the nature, duration and objective of the experiment; experimental methods; all possible inconvenience and risks; the consequences of the experiment for the health and moral well-being before submitting the consent". [ibid.]

${ }^{3}$ Another variant of such mismatch is the use of IC to euthanasia. However, the details of the issue fall outside the scope of our study.

${ }^{4}$ One female patient said: "I was offered to submit IC; after a conversation I felt like I had been molested" (private message to NZ). Yes, the patient has a right to refuse to be informed and to choose. However, this right is usually realized after conversation with the physician

${ }^{5}$ By the way, regardless of the "freedom", W Vlasov does not like such a choice: "Unfortunately, the wretched Russian law provides for "consent to intervention" and "refusal to intervention". Thus, the patient is forced into synthetic situation of choosing between treatment and no treatment. The fact in concealed (?NZ) that consent submission is a form of treatment option selection, which is provided for by the law, pointing out the necessity to inform the patient about "other treatment options". (?NZ) [lbid.].
} 
Actually, unless someone is unaware, real patients (in case of no serious life threat) are being affected by various illnesses and use the treatment options as they see fit [10].

And now, let's imagine the impossible. There lives an intelligent, conscientious and honest physician, who "has the knowledge about all the proposed interventions", even the knowledge no one else has (i.e. knowledge about the COVID vaccines). He has no unconscious mind, but only conscious awareness. Perhaps, he may also have a natural skill to talk to other people in a way that his words are understood by every person (regardless of daily learning of lessons that all people do is fail to understand each other...). There also lives an awesomely smart, honest and "motivated" patient, who is free of unconscious processes, two-facedness and ulterior motive, just like the physician... For some reason, his disorder has not affected his ability to hear kind and supportive words. And both of them, motivated by mutual affection and the desire "to inform and to be informed", meet in the extraordinary space; they also have more than enough time to talk about everything. After all, let's ask ourselves: "Is that free choice really possible?"

It is a suitable time to recall the words from the epigraph: "...Securing agreement on general claims (like "respect human beings") is easy but securing agreement on the meaning of these claims is not". That is, the general principle "the patient has a right to be informed" is not (and cannot be) satisfactorily implemented in private manner.

And we're back to the fact that the existing form of IC explicitly or more often implicitly suggests that all people are the same ${ }^{6}$. In other words, psychological aspects of decision making (to accept/not to accept) are not taken into account by the law. That is why the diversity and complexity of the internal picture of the disease together with understanding the purpose of patient's visit to the doctor [10] are replaced by the process agreement. All the technological clarifications concerning the interaction between the parties ("delicately", "gradually", "amply", "in simple terms", etc.) appear to be the flirty smile of the Market towards humanism and good intentions.

"It is enough for the physician to one day become a medical practice's customer to experience firsthand the illusion of the declared medical "moral progress", as well as the pharisaical, hypocritical nature of requirements for the customer stated in the listed above declarations: "to have adequate (?NZ) knowledge" in order to "make an informed free choice". "Adequacy", "mindfulness", etc., are the fundamentally nonoperationalizible terms (either being non-verifiable, or being verifiable in theory through specific conventional long-term psychological research). And, if so, once spoken aloud these words immediately become mottos. In the contemporary medical education arrangement system there are no physicians having "adequate knowledge", to "make informed decisions" while acting as a patient, in case the issue goes beyond their narrow specialization, not to mention the non-physicians, and the fact that in an era of the Fourth Estate no decision could be called free. Freedom has been successfully substituted by mottos about Freedom" [12].

Makes you wonder if anybody knows this. Many physicians are well aware that the "free choice" is simply impossible. For example, by definition, as "life constrained in its freedom" ( $K$. Marx) can't possibly be free to choose. At their best, physicians and patients are left to rely on intuition, and in the worst case they are left to mimic sort of mutual agreement.

This looks especially cynical and prominent in case of obtaining the IC to mercy killing (euthanasia). For example, a 12-year-old adolescent (Netherlands) is expected to be aware of the meaning and consequences of the situation, and certain physician (usually psychiatrist) is thought to be able to ascertain this. Situation of IC in mentally disabled patients is no better [ibid.].

A few implicit self-deprecating assumptions can be discerned in the reform efforts of Russia, suffering from the national inferiority complex since ancient times: that society together with ethics always develop progressively; that the Western medicine is obviously by all accounts better than other kinds of medicine; that it is scary to have a reputation of retrograde and supporter of "undemocratic solutions", as well as of paternalism supporter, etc. With that attitude of the situation we are in danger of losing our autonomy.

\section{Conclusion}

First, the experimental procedure (for which the IC process was originally created) differs significantly from daily medical practice, whereas there has been no substantive change in IC. This is one of the reasons why a large number of physicians reject IC. Perhaps, the fundamentally different IC forms should be developed for different situations: for clinical trials (CT), for disorders (IC to intervention), for euthanasia ${ }^{7}$, etc.

Second, the IC Law "for every person" in used in Russian clinical practice, i.e. it is a part of the species survival strategy. There is no (and, perhaps, there cannot be any) satisfactory mechanism of the Law implementation under the individual survival strategy, i.e. the application of the Law to a certain individual.

Third, we have a reason to believe that nowadays the problem of IC in certain patient has no other solution than to remain the legal construct servicing the market economy. As such, this is reasonably necessary. We should treat declarations on freedom and desired voluntary bounds accordingly. We have to admit that the only truly free patient's choice is the choice of refusal to be informed and shifting the responsibility onto physician.

Fourth, it's quite possible that the future attempts at improving the IC Law would require getting back with "obsolete" values of classical medicine.

${ }^{6}$ «While understanding the psychological aspects $<\ldots>$ interests did not always coincide, i.e. have the same objects. That is why those, who try to prove the coincidence of interests on the basis of the human nature unity, fail to achieve the desired goals» [11] (p .466).

${ }^{7}$ Unfortunately, you can be sure that the issue of euthanasia legalization in Russia would be raised.... 


\section{References}

1. Symons $X$. Can we synthesise Christianity moral theology with secular bioethics? BioEdge, 2020. https://www.bioedge.org/ bioethics/can-we-synthesise-christianity-moral-theology-withsecular-bioethics/13629/.

2. Tishhenko PD. Zhizn' i vlast': bio-vlast' v sovremennyh strukturah vrachevanija, Zhurnal'nyj klub «Intelros» Biojetika i gumanitarnaja jekspertiza» №4, 2010. URL: http://www.intelros.ru/pdf/ Bioetika/4/03.pdf/ Russian.

3. Zorin NA. Krugovorot porokov, boleznej i dobrodetelej, Al'manah Centra issledovanij jekonomicheskoj kul'tury. Special'nyj vypusk "Jekonomika porokov i dobrodetelej". M., SPb.: Iz-vo Instituta Gajdara., 2016; 150-170 p. https://www.academia edu/37962771/ Russian

4. Cain R. How neoliberalism is damaging your mental health. 2018. https://theconversation.com/how-neoliberalism-is-damagingyour-mental-health-90565

5. Zorin NA. Bezgreshnye retransljatory Izhi ili mehanizmy perekladyvanija viny $v$ medicine, kak forma legitimizacii obmana. https://www.academia.edu/42222674/ Russian.

\section{Литература}

1. Symons $X$. Can we synthesise Christianity moral theology with secular bioethics? BioEdge, 2020. https://www.bioedge.org/ bioethics/can-we-synthesise-christianity-moral-theology-withsecular-bioethics/13629/.

2. Тищенко П. Д. Жизнь и власть: био-власть в современных структурах врачевания, Журнальный клуб "Интелрос» Биоэтика и гуманитарная экспертиза» 2010;4. URL: http:// www.intelros.ru/pdf/Bioetika/4/03.pdf/.

3. Зорин Н. А. Круговорот пороков, болезней и добродетелей, Альманах Центра исследований экономической культуры. Специальный выпуск "Экономика пороков и добродетелей". М., СПб.: Из-во Института Гайдара., 2016; 150-170 c. https:// www.academia.edu/37962771/

4. Cain R. How neoliberalism is damaging your mental health. 2018 . https://theconversation.com/how-neoliberalism-is-damagingyour-mental-health-90565.

5. Зорин Н. А. Безгрешные ретрансляторы лжи или механизмы перекладывания вины в медицине, как форма легитимизации обмана. https://www.academia.edu/42222674/.
6. Vlasov $\mathrm{W}$. Informirovanie pacienta i ego soglasie na lechenie. http://osdm.org/blog/2020/08/22/informirovanie-pacienta-i-egosoglasie-na-lechenie/\#more-16568/ Russian.

7. Forum Vrachi RF. Podborka statej o kljatve Gippokrata. https:// vrachirf.ru/search?query/ Russian.

8. King $\mathrm{H}$. Hippocrates didn't write the oath, so why is he the father of medicine? The Conversation 2014. https://theconversation. $\mathrm{com} /$ hippocrates-didnt-write-the-oath-so-why-is-he-the-fatherof-medicine-32334.

9. Dawes M, Summerskill W, Glasziou P. et al. Sicily statement on evidence-based practice. BMC Med Educ 2005;5: 1. https:// doi.org/10.1186/1472-6920-5-1 https://bmcmededuc. biomedcentral.com/articles/10.1186/1472-6920-5-1/.

10. Zorin NA. Zachem bol'noj prihodit k vrachu? Glavnyj vrach, 2002; (2): 62-65. https://www.academia.edu/41037041/ Russian.

11. Ossovskaja M. Rycar' i burzhua: Issled. po istorii morali. Gusejnov AA. redaktor. M.: Progress, 1987; 528 p. Russian.

12. Zorin NA. Ubej menja nezhno ili lechenie smert'ju (ob jevtanazii) Chast' I. Zhurnal im. P.B.Gannushkina. 2021; (23): 34-44. Russian.

6. Власов В. В. Информирование пациента и его согласие на лечение. http://osdm.org/blog/2020/08/22/informirovaniepacienta-i-ego-soglasie-na-lechenie/\#more-16568/.

7. Форум Врачи РФ. Подборка статей о клятве Гиппократа https://vrachirf.ru/search?query/.

8. King H. Hippocrates didn't write the oath, so why is he the father of medicine? The Conversation 2014. https://theconversation. com/hippocrates-didnt-write-the-oath-so-why-is-he-the-fatherof-medicine-32334.

9. Dawes M., Summerskill W., Glasziou P. et al. Sicily statement on evidence-based practice. BMC Med Educ 2005:5: 1. https://doi.org/10.1186/1472-6920-5-1 https://bmcmededuc. biomedcentral.com/articles/10.1186/1472-6920-5-1/.

10. Зорин Н.А. Зачем больной приходит к врачу? Главный врач, 2002; (2): 62-65. https://www.academia.edu/41037041/.

11. Оссовская М. Рыцарь и буржуа: Исслед. по истории морали. Гусейнов А. А. редактор. М.: Прогресс, 1987; 528 с.

12. Зорин Н. А. Убей меня нежно или лечение смертью (об эвтаназии) Часть І. Журнал им. П.Б.Ганнушкина. 2021; (23): 34-44. 


\title{
INFORMED CONSENT: FROM HISTORIC ROOTS TOWARDS THE RED LINE OF MODERN CRISES IN INFECTIOUS DISEASES
}

Kubar OI $\otimes$, Bichurina MA, Romanenkova NI

St. Petersburg Pasteur Institute, Russia

Stages of the informed consent (IC) process, being the instrument for protecting the rights and dignity of the research subjects, ideology and essence development during the crises in medicine have been studied on the example of the infectious diseases. Special emphasis has been placed on the 100-year national history of the informed consent ethical and legal principles development. The review of information process content and logistic improvement (individual, public, delayed and broad IC) during vaccine testing and vaccination in emergency settings has been provided. Implementation of the WHO programmes aimed at eradication of preventable infections (polio, measles) illustrates the coherence of adherence to awareness-raising ethical standards with the success of epidemic control. The development of preventive vaccination ethical algorithm and the practice of its use during the epidemic crises have a significant predictive value for organization and control of using the vaccines during the pandemic.

Keywords: informed consent, history and development informed consent, IC in vaccine research, IC in vaccination for emergency reasons.

Author contribution: Kubar OI — Historical and archival study and review of the formation and development of research ethics in Russia; analysis of the specifics of informed consent in vaccine research and development of an ethical algorithm for the control of emergency epidemic situations. Bichurina MA, Romanenkova $\mathrm{NI}-$ carrying out a complex of virological and epidemiological studies in the format of the WHO Subnational Laboratory for the Elimination of Preventable Infections.

$\triangle$ Correspondence should be addressed: Olga I. Kubar

Mira st. 14, St. Petersburg, 197101, Russia; okubar@list.ru

Received: 18.02.2021 Accepted: 20.03.2021 Published online: 31.03.2021

DOI: $10.24075 /$ medet.2021.010

\section{КОНЦЕПЦИЯ ИНФОРМИРОВАННОГО СОГЛАСИЯ ОТ ИСТОРИЧЕСКИХ КОРНЕЙ ДО КРАСНОЙ ЛИНИИ СОВРЕМЕННЫХ КРИЗИСНЫХ СИТУАЦИЙ В ИНФЕКЦИОННОЙ ПАТОЛОГИИ}

\author{
О. И. Кубарь $\square$, М. А. Бичурина, Н. И. Романенкова \\ Санкт-Петербургский НИИ эпидемиологии и микробиологии имени Пастера, Санкт-Петербург, Россия
}

\begin{abstract}
Проведено изучение этапов процесса развития идеологии и содержания информированного согласия (ИС) как инструмента защиты прав и достоинства участников исследований и в кризисных ситуациях в медицине, на примере инфекционных заболеваний. Специальный акцент сделан на более чем 100-летний период отечественной истории становления этических и правовых принципов формирования информированного согласия. В отдельном разделе дан обзор совершенствования содержательной и логистической характеристики процесса информирования (индивидуальное, общественное, отсроченное и широкое ИС) при испытании вакцин и проведении вакцинации в чрезвычайных ситуациях. На примере реализации глобальных программ ВОЗ по ликвидации управляемых инфекций (полиомиелит и корь) продемонстрирована сопряженность следования этическим стандартам информирования и достижения успеха противоэпидемических мероприятий. Создание этического алгоритма вакцинопрофилактики и опыт его применения в кризисных эпидемических ситуациях имеет важное прогностическое значение при организации и контроле применения вакцин в период пандемии.
\end{abstract}

Ключевые слова: информированное согласие, история и совершенствование форм ИС, ИС при исследовании вакцин, ИС при вакцинации в чрезвычайных ситуациях

Вклад авторов: Кубарь О.И. - историко-архивное изучение и обзор становления и развития этики исследований в России; анализ специфики информированного согласия при исследовании вакцин и разработка этического алгоритма контроля чрезвычайных эпидемических ситуаций. Бичурина М.А., Романенкова Н.И. - проведение комплекса вирусологических и эпидемиологических исследований в формате Субнациональной лаборатории ВОЗ по ликвидации управляемых инфекций.

$\bowtie$ Для корреспонденции: Кубарь Ольга Иосифовна ул. Мира 14, Санкт-Петербург, 197101; okubar@list.ru

Статья получена: 18.02.2020 Статья принята к печати: 20.03.2021 Опубликована онлайн: 31.03.2021

DOI: $10.24075 /$ medet.2021.010

Responsible adherence to the norms of law and morality (ethics) is a historically justified constant of public health system management and regulation. However, we need to acknowledge that adherence to normative and ethical principles is essential in the context of logistic changes resulting from new challenges related to scientific progress or global health emergencies. In the circumstances, due respect to human dignity, rights and fundamental freedom truly plays a crucial role, and the ethics reaches the level of the conflict of interest resolution and the benefit/risk/damage balance criterion. The priority role of ethics, in turn, requires continuous improvement of multidisciplinary and pluralistic dialogue between all parties concerned based on objectivity, openness and trust.

Achieving the doctor-patient mutual understanding, where special responsibility belongs to information exchange and the parties' consent, is the universal instrument that ensures protection of human dignity throughout many centuries of the history of medicine.

The cultural diversity features importance for the information process building led us to appeal to the base of this phenomenon documentation in Russia, as well as to the dynamic changes in development in the specific context of extreme pressure on the healthcare systems associated with control and management of infectious diseases.

\section{METHODS}

Methodological approach used in our study consisted in exploratory research and consistent reporting of the informed consent development and implementation in Russia covering 
the periods of imperial Russia, USSR and modern Russian Federation. Archival documents, legal acts and printed matter issued from 1902 to date were revised 1, 2]. The national and international legal acts, including the guidelines for good clinical practice (GCP), UNESCO and WHO documents developed with the author (having the status of the WHO expert and the UNESCO IBC member) assistance, were analyzed in order to demonstrate the dynamic changes in the informed consent development and implementation features during clinical trials and the use of vaccines $[3,4,5]$. Special attention was paid to investigation of the $\mathrm{WHO}$ programmes aimed at eradication of polio, measles, rubella and congenital rubella $[6,7,8,9]$. The section on assessing the IC role in eradication of preventable infections is based on methodological resources of the $\mathrm{WHO}$ guidelines and direct experience of such programmes implementation within the framework of managing the polio/ measles/rubella WHO subnational laboratory $[10,11,12]$.

\section{RESULTS}

Examining the origins of the informed consent institutions formation in Russia was the initial phase of our study, which defined our interest to understand the dialectic of relationship between law and ethics in medicine. The task ahead was to assess the contingence and mutual influence of historical moral foundations underlying national bioethics based on the experience of implementation in critical epidemic situations. These developments had a special resonance and were of key relevance in the context of the COVID-19 pandemic, under which both national sovereignty conflicts and specific morality of national consciousness had become apparent [13].

In that regard, it is extremely important to note the moral high ground of the medical profession peculiar for Russian statehood that is reflected in a series of historical and cultural papers $[14,15,16,17]$. Of particular note is some written evidence of moral and legal regulation of communication, which has been presented earlier in a special series of reviews [1, 2].

According to chronology of the research, the first available publication was concerned with the moral regulation of health activities based on the example of the trial of Dr. Modlinsky, who was found guilty of "failure to ask the patient for consent" by the Criminal Cassation Department of the Senate of the Russian Empire [published in the "Legal Drama" magazine, 1902, No. 2]. This example suggests that it was legally recognized obligation to obtain the patient's consent to medical intervention in Russia in the early 20th century, and the regulatory framework existed for sanctions related to non-compliance with this legal rule. The principle of morally graded attitude to the fact of patient's was obligatory too, as was clear from the comment given by professor of criminal law Tagantsev: "the patient's consent is powerless to grant impunity in all cases of healing" (published in the "Law" magazine, 1902, № 12) [1, 18, 19].

The truly unique paper by Dr. B.V. Dmitriev "Thyroid Gland Transplantation Case and Legal Issues Related to Such Transplantation", published in 1917, is the irrefutable proof of the legal recognition of the medical research involving human subjects in the imperial Russia [20]. This paper presents the full list of major ethical requirements for conducting such surgical interventions, among which is the obligation to inform both donors and recipients about all the potential consequences of medical intervention. The requirements for the donor's physical and mental health are also emphasized, as well as the need for the "transient and mild nature of injuries", guaranteed by the doctor. The text of the note written by the female patient E.P., presented in the paper by Dr B.V. Dmitriev, is of historical value. The note is blatantly obvious to be contingent with the current standards for the ethically acceptable elements of the contemporary IC process [20, p. 628]. The original text of the note contained the list of items common to all up-to-date international instruments on bioethics, such as confidentiality, respect for autonomy, risk awareness, respect for freedom and voluntariness of decision-making, and the need to consider the social and psychological maturity of the person being the research subject. All of the above defines our point of view that this note is essentially the first fully valid example of the patient informed consent form, possibly not only in Russia [2].

Legal sufficiency and completeness of this fact are substantiated by the concept developed by A.F. Koni, one of the most respected Russian lawyers, who stated that there was no criminal activity in selling organs for medicinal purposes [20, p. 629-630]. The legally recognized contract between the donor and the recipient, containing provisions for exclusion of "minors, mentally retarded people, and people being in the state of artificially induced excitement", was indispensable for the legality of such an action; furthermore, the concept stipulated that the decision on participation had not had to be provoked by "psychological coercion, deception, seduction, profit, or authoritative suggestion", i.e. in modern terms the decision had to be free and informed.

Thus, the analysis of the relationship between ethics and law in the early 20th century Russia suggests that the humanistic ideas of voluntary, confidentiality, and informed nature of the research subject decision-making took place together with the responsibility and mercy of the physician-scientist and regulations in force. This highlighted the rich moral heritage and bioethics potentiality of Russia [14, 17].

When discussing the historical perspective, we should highlight the ethical and legal regulation of medical and biological research in the former USSR. Studying the legal instruments available revealed that already in the first years of the Soviet power's existence the Act of the RSFSR dated December 1, 1924, "On the Professional Work and Rights of Medical Workers" clearly specified the need for "the patient's consent, in particular when conducting surgical procedures", and the fact that "in individuals under 16 or mentally disabled individuals" the "consent of their parents or guardians" was essential. The Resolution of the Scientific Medical Council of the People's Commissariat of Health Care of the RSRSF "On the Conduct of Study of New Medicines and Medical Methods Associated with Risk for the Life and Health of Patients", issued in 1936, was unique [21]. The reasons and grounds for such instrument development and acceptance were explained in detail in the paper by private associate professor IYa Bychkov "On the Issue of Legal Regulation of Medical Experiments Involving Human Subjects" [18]. It is important to note the compliance of experimental procedure with modern requirements in terms of scientific data validity and preliminary survey on animals; informed consent of the research participant; requirements for high physician-scientist qualification and his/her responsibility towards the study participant. Among the historic documents reviewed, the USSR legislation in the area of "crimes against humanity" applied during the trial of the former military officers of the Imperial Japanese Army, charged with the development and use of bacteriological weapons, conducted by the Military Tribunal of the USSR in December 1949 in Khabarovsk (Article 1 of the Decree of the Presidium of the Supreme Soviet of the USSR of April 19, 1943), deserves special attention [1].

In general, historical recollection suggests that in varying political and socio-economic situations during the studied period, national health care was based on the sense of morality 
and responsible approach to scientific research involving human subjects. Later, in the course of improving the research and educational potential, as well as the harmonized integration of modern Russia in the development of global bioethics, the full-fledged legal framework for ethical issues in medicine and biology was formed [17].

This provision is extremely important at the current stage of the health care development, especially in emergencies requiring accomplishing the goals of global interaction and solidarity, such as elimination of infections and epidemic management during the pandemic. In both situations, preventive vaccination and the associated element of "dual loyalty" to the rights of the individual and of society are of key importance [9]. In this regard, correct presentation of the complex of ethical awareness and actions in the abovementioned conditions requires understanding of contemporary structure and conceptual changes in the informed consent process with the focus on testing and using the vaccines.

Investigation and analysis of contemporary informed consent framework was the next important stage of the study. The existing standards of the informed consent as a primary mechanism for the protection of the rights of biomedical research participants include a number of essential elements, such as the fact of obtaining the voluntary IC, guaranteed accessibility of information, as well as objectivity and specific nature of the process in vulnerable populations. The other essential factors ensuring protection of the research subject rights are as follows: review/approval by the ethics committee (EC), and conformity with national law [4, 5, 23-27].

Since this paper directs by testing and using the vaccines, the significant elements of the informed consent process specific for this area are especially important. In general IC protects the freedom of individual choice and ensures respect for the individual's autonomy. These qualities assume special importance during studies showing no immediate and direct effects, which include vaccine trials. Under the circumstances, the IC should provide clear and true information not only about the study, but also about the possible alternatives. IC should ensure the possibility of dynamic discussion of the questions raised by the study participants (before/in the course of/after the study). During the vaccine trial, potential participants have the right to receive the advice about the risk of infection and any steps that could be taken to reduce the risks. The correctness of this fact has been unequivocally confirmed by testing the vaccines against such infectious diseases as COVID-19.

The social aspect of the perception that the informed consent is a two-way communication process that also involves voluntary consent, given by the participant, and the IC, received by the researcher, is very important. The structure of the IC information block should be discussed in detail, which includes, but is not limited to information about the goals, methods, funding sources, possible conflict of interest, and institutional affiliation of the researcher, expected benefits, potential risk/discomfort, and access to study results. The IC process should not be considered as one-off and static process, since the researcher must once again provide the up-to-date information and obtain the new IC from the participants in case of significant changes occurring at any stage of the study. Certainly, it is necessary to ensure the potential participant's ability to understand the information, which is directly related to the presentation of characteristics mentioned in the IC (in the mother tongue, with no medical terms), to the person's maturity, educational level and beliefs, as well as to the researcher's ability and willingness to create an environment of trust.
When conducting contemporary research, introduction of the new format, the so-called "broad" IC, should be taken into account. Broad IC involves consent to storage/future use of biological specimens that remain after the study and are used for other purposes. Broad IC stipulates that it can be withdrawn using the informed refusal procedure, which in turn includes a number of issues discussed below. Prior understanding of the refusal acceptability by the participants is required; moreover, the information sufficient to make such a decision should include the possibility to withdraw the previously submitted broad IC, and confidence in the participant's availability for the refusal procedure. There are special provisions for individuals unable to submit the $\mathrm{IC}$ at the beginning of the study (e.g., children). In this case, the procedure of obtaining the individual IC or the refusal of the previously submitted by the children's guardians broad IC is specified for the situation of acquiring full legal capacity in the future. The fact of the broad IC acceptance must necessarily be reviewed and approved by the EC. There are several exceptional situations where the ethics committee might not necessarily require the individual IC to the future use of the retrospective study data. Such situations are as follows: the study is impossible in case of refusal; the study is of great social significance; the study poses minimal risk for the subject or the community, the subject belongs to. However, even in these situations, safeguards for information confidentiality protection ensured by anonymized or encoded data exchange, or limited access to data for the third parties, is an essential component.

For international studies, it is necessary to take into account the developer/sponsor obligation to return all specimens/data to the country of research, as well as to share all the potential results and benefits. It should be noted that the broad IC is also applicable in cases, when the materials collected could be potentially used for the common good during the subsequent research, the exact nature of which is usually unknown at the time of collecting the materials. This does not allow for the information block specifying, and makes broad IC the acceptable alternative [5]. The latter issue is no doubt substantial from the social and epidemiological point of view; therefore, it might be applicable in emergencies, such as elimination of infections and the pandemic.

In the format of this discussion, it is significant that the broad IC to storage of biological specimens envisages certain limitations concerning their future use, and must include information about the goals, conditions and period of storage, as well as the details of the access policy and the means of raising awareness about the use of biomaterial (i.e., the use for the subject's health with subsequent destruction, the use for the well-known research projects, or storage for the inconclusive purpose). Such alternatives provide basis for introduction of the new term, the "tiered" IC, allowing one to choose the appropriate setting for the storage of his/her biomaterial.

Thus, in view of the foregoing, it is obvious that, when performing ethical review of the new vaccine trials, special attention should be paid to the issues of the collected biological specimens and/or data carriers (medical records) future use. As mentioned above, the researcher's responsibility extends to obtaining the appropriate IC. Responsibility of the EC extends to reviewing supplementary or broad IC, as well as to ethical evaluation of the fact and the grounds of the biological specimens collection (including the commercial purposes), storage period, broadness and the terms of acceptability during the future research projects.

The issue of the researcher and sponsor obligations to ensure the subject's right to compensation or necessary 
additional medical care merits a separate discussion. Furthermore, the procedure and the measure of compensation for study (e.g., new vaccine trial) participation should be reviewed, justified and explained to participants. It should be emphasized that the compensation does not provide for the mandatory financial component, and can be implemented via free medical care during the study, as well as via access to a number of services: insurance, examination, health education. Special types of compensation are possible when conducting research involving volunteers. However, it must be borne in mind that the compensation cannot be used as a means of pressure or coercion for decision making during the IC process anyway. A solution to the issue of the fact and form of compensation (or the fact of no compensation) is a subject of ethical review performed by the EC. It should be taken into account that the participants have a right to free treatment and compensation in the event of harm (physical, psychological or social), directly related to participation in the study. The nature and measure of the compensation, including the cases of disability and death, should be detailed in the IC information block and are the special subject to review by the EC. It should also be emphasized that the right to compensation for caused damage/harm is, on top of everything else, of great moral importance in maintaining the clinical trials credibility.

The fact that all the aforementioned data are fully applicable to individuals capable of making decisions independently due to their mental status, age and social background is an important logistical issue. When dealing with vulnerable populations, the IC process is addressed to the study participant's legal representative (parent, guardian or other authorized person). According to GCP ethical standards, the research involving vulnerable populations can be conducted only on behalf of such individuals provided that the research is aimed at getting immediate or potential benefits, the study cannot be conducted in other populations, and the risk and discomfort related to study participation are insignificant compared to the expected benefits. Special regime of conducting the studies involving various vulnerable populations is defined in each case based on the universal ethical principles, which include respect for cultural and social diversity, and are recognized by law allowing for special conditions for protection of individuals unable to give the informed consent. The arguments advanced here may produce a significant resonance when testing and using the vaccines during the epidemic crises, when the high coverage levels of vaccination with potential enrollment of individuals with different social status have to be achieved [5, 24].

It is evident from the above that within the focus of this study aimed at defining the features of IC in case of infection outbreaks in order to prevent or eliminate the outbreaks by vaccination, the socially significant aspect of the studies involving large populations (among them the vulnerable groups) is particularly important. Such studies make it possible to accomplish important tasks of fast knowledge-building, building public trust, and overcoming practical difficulties in specific circumstances. However, these tasks should be carefully balanced against the scientific validity of the study and the guarantee of respect for the participants' rights. The facts of speeding up the review, and application of EC action priority evaluation in emergency situations are envisaged and permitted under these circumstances [13].

Cluster studies may be considered an acceptable form of the research. Such studies provide for enrollment of distinct groups (for example, schools, hospitals, other institutions or departments, i.e., the clusters) that are subject to randomization in order to investigate various means and methods of medical interventions. Conducting such studies requires specifying ethical approaches: clearly defined individual study participant, defining the nature of the influence on other individuals or community, the need to obtain the IC from the community representatives, as well as consideration of the degree, to which the IC or refusal to give the IC can justify or compromise the study results. Arrangement of such studies always faces the need to address the ethically significant issue of the control group eligibility, and the need to discuss the project with independent experts. An example of specific ethical conflict can be introducing the new infection control procedure (vaccination) in one cluster without modifying the procedures in the control cluster; this situation is analogous to the use of placebo, which could trigger the need for post-marketing surveillance of the vaccines. Meanwhile, there are always the conditional measure and the level of decision making capacity. For instance, when a school is selected as a cluster, the students' parents cannot give the consent to randomization of the school, attended by their children, for the vaccination programme, or to exclusion of the school from the cluster. However, they can accept or reject their children's participation in the vaccination programme [5].

In the current context of conducting research and practical arrangements for the preventive vaccination, it is necessary to take into account the new technologies, such as Internet (social media, websites, chat rooms), which, apart from the clearly considerable benefits (accessibility, communication speed), pose additional risks for establishing and maintaining confidentiality. The need for confidentiality primarily extends to keeping secret information, making it possible to determine the participant's identity, and other information subject to nondisclosure provisions from the unauthorized persons. Moreover, when conducting the study results analysis in terms of potential data disclosure impact on the possibility of the data use for discrimination of certain groups and human communities, it is essential to follow the principle of confidentiality. Assurance of confidentiality during epidemiological research involving the use of Internet (both for mailing and research data acquisition/ storage, depending on the specific conditions and levels of protection) requires mandatory inclusion in the text of the IC with subsequent approval or refusal both of the designated authorities together with the ethics committee, and the used website owners $[4,5,12]$.

In spite of the fact that our study is focused primarily on the crucial role of the informed consent being a vital force in the protection of the rights of the research subjects, it should be strongly emphasized that this goal can be achieved only under the full complex of ethical support, which includes, in addition to the IC, independent review by the EC, and the recently developed third element, public accountability. Negative, inconclusive, and positive results must be published or made available to public in any other way. Such format is intended to maximize the research benefits, reduce social tension by disclosure of risk/harm, reduce the time required for decision making, increase the resource allocation efficiency, avoid overlapping, conduct an independent evaluation, and contribute towards building trust on the part of the society as a whole [5].

Therefore, only the three-component ethical element of vaccination that includes $I C$, and independent social feasibility recognized by society, demonstrates openness, timeliness, objectivity and relevance. In view of the above, we must point out that this exact supranational and interdisciplinary approach largely determines current trends in the development of biomedical ethics; it also allows for seeking justice in distribution of benefits/damage/ costs/risks, resulting from scientific and 
technological progress in biomedicine, among countries. In this context, the trends in global bioethics become more and more evident. Global bioethics focuses not only on individual, but also on social values, intended to reveal the ethical nature of socially significant settings and situations, which should obviously include preventive vaccination.

In terms of ethics, the area of using the vaccines during health emergencies is the most important focus of creating the unified ethical approach. Extreme conditions during such situations are comparable to research, as they are related to unknown and unpredictable circumstances. In such a case the issue of providing authoritative information, as well as of conscious acceptance and response to information both in the individual and the society as a whole, becomes crucial for success.

\section{DISCUSSION}

Examining the role of the informed consent in the WHO infection elimination programmes is the key element for understanding the informational aspects of the research. The authors' direct participation in the $\mathrm{WHO}$ programmes aimed at eradication of a number of preventable infectious diseases (polio, measles, rubella, and congenital rubella) made it possible to determine the true role of the correct information process development, as well as to identify the features of the IC structure and forms in the context of the large-scale international events. May 13,1988 , the date of the $41^{\text {st }}$ World Health Assembly (WHA) Resolution adoption, should be considered the official start of the polio eradication programme. The Resolution urged all countries to coordinate their efforts in order to eradicate polio by the end of 2000 [6-8]. Since the programme was considered critically important, the requirements for highcoverage vaccination against polio, conducting clean-up immunization in populations with low immunization coverage, and maintaining highly effective polio surveillance until the end of the programme entered into force. The global efforts great force was ensured by the following: involvement of 200 countries, territories and regions; participation of 20 million volunteers; vaccination coverage of more than 2 billion children. In terms of ethics, it was important that the polio eradication programme sociopolitical and economic components were based on the principles of international solidarity, social responsibility, and respect for cultural, historical and religious diversity. We conducted comprehensive study of the ethical algorithm for global infection elimination and presented the results in a series of papers [10-12]. Within the framework of this study, it was important to examine and define the predictive value of the ethical block information component.

Thus, correct and successful implementation of the programme, apart from coherence at the global level, correct recording, and the use of scientific and economic resources, was definitely impossible without the civil society support. Engagement with society necessitates the implementation of appropriate educational measures, equal access to training of personnel, and availability of specific public information. All decisions and acts should target different audiences and groups of people, different in social, cultural and religious composition. Efforts in education and raising public awareness during implementation of the infection elimination programme dictate adherence to the ethical principles of openness, objectivity, honesty and accessibility. Moreover, rapid investigation of the population reaction to measure implementation is required, together with the rapid response. Such type of monitoring is intended to restore a just information risk-benefit balance, prevent misinformation and confusion, and, as a consequence, ensure mutual trust and solidarity with society. Shaping the population attitudes by sensitizing to objectives and methods of the polio eradication programme worldwide can be considered a good example of adequate information policy. This is conclusively demonstrated by the modalities of the Polio National Immunization Days implementation in India. A huge amount of operational activities took place during 6 immunization days officially declared by the country, including opening of 640,000 vaccination centers, involvement of 2.3 million vaccinators and 137,000 curators, visits to 191 million households, which ensured vaccination of 172 million children [10, 11]. In terms of ethics, when implementing such large-scale measures, special attention should be paid to development of the information block, as well as to efforts to obtain the informed consent to participation of general public using a differentiated approach to vulnerable populations and guaranteeing the right to the protection of privacy and confidentiality. During implementation of the whole range of global measures aimed at polio eradication, adaptation and actualization in different countries and populations were achieved through country visits and the analysis of follow-up data obtained for acute flaccid paralysis, as well as through comparison with data of regional reference laboratories and communication with national technical partners. The inclusion of the "Institutional Memory and Lessons Learned" programme mechanisms was essential. The programme provided for information types differentiation, as well as screening of quality and significance of information blocks by the use of more detailed subnational database containing data on epidemiology of other preventable infections. Only the whole range of the listed above measures could ensure transparency and accessibility of information about the organizational and operational efforts of the national system in the course of polio eradication.

Thorough review and analysis of events, that took place at the stage of acceptance and implementation of the new WHO global measles, rubella and congenital rubella elimination initiative, provided extensive and convincing data supporting our previous conclusion made after investigation of the polio eradication programme ethical algorithm [9, 12]. The compulsory measures to provide the two-time postponement of implementation of the $\mathrm{WHO}$ strategic plan for elimination of these infections at national, regional and global levels (from 2010 to 2015 at the first stage, and from 2015 to 2020 at the second stage) owing to non-synchronous preventive measures clearly demonstrate the fundamental importance of the joint efforts of all systems of information management, governance and control of epidemic process for achieving the effect. Implementation of measures in various parts of the world in the populations with different cultural, social, religious, economic and psychological status requires commitment to the ethical principles of human vulnerability recognition, respect to cultural diversity and inviolability of the person, as well as equality, justice, equal rights and pluralism. This resource of ethical filling should clearly be taken into account and should dominate in achieving the public and individual informed consent with guaranteed free informed decision making. At the same time, data integrity ensures efficient functioning of all scientific research elements, both in laboratory practice and in vaccine improvement [12]. The tangible achievements may be based on the ethics of transnational interaction practices, the compliance with which contributes to sharing new technologies, as well as on professional training and bioethics data [3]. 


\section{CONCLUSION}

Thus, ensuring the humanitarian success of the infection elimination measures requires building the ethical component of the programme and inclusion of this component into plans and operational documents as an integral part in order to achieve ethical integrity of decisions and actions at all levels of governance. The existence of ethical standard obliges all the parties involved to maintain and develop the relationship of solidarity, personal and social responsibility, justice, openness and accountability within the civil society at the professional, state and interstate levels.

In general, summing up the interdisciplinary analysis of the informed consent value for achievement of epidemiological welfare, there should be a clear recognition of the feasibility of compliance with its humanistic essence together with recognition of the need for considering the best ways to follow the IC process during the pandemic crises.

\section{References}

1. Kubar' Ol. Eticheskie i pravovye problemy issledovanij na cheloveke: iz istorii Rossii XX veka. Zhurnal "Chelovek". 2001; 3; 9-15 p. Russian.

2. Kubar OI. Research involving human subjects: ethics and law in early 20th century Russia, Bull. Med. Eth., 2001 October; 13-17 p.

3. International Declaration on Bioethics and Human Rights. UNESCO, Paris, 2005. http://www in. unesco.org.

4. International ethical guidelines for epidemiological studies CIOMS, Geneva, 2009; 130 p. https://cioms.ch/publications/ product/international-ethical-guidelines-for-epidemiologicalstudies/.

5. International Ethical Guidelines for Health-related Research Involving Humans - CIOMS, Geneva, 2016; 119 p. https:// cioms.ch/wp-content/uploads/2017/01/WEB-CIOMSEthicalGuidelines.pdf

6. Global'naya likvidaciya poliomielita. Otchet o pyatom soveshchanii Global'noj tekhnicheskoj konsul'tativnoj gruppy po likvidacii poliomielita, ZHeneva, 2000; 40 s. Russian.

7. Global'nyj konsul'tativnyj komitet po bezopasnosti vakcin // Kachestvo i bezopasnost' vakcin, nachinaya ot in razrabotki do vvedeniya pacientam. Informacionnyj byulleten' VOZ, 2005; 295 p. http://www.who. int/vaccine_safety/committee/en.

8. Global Immunization Vision and Strategy WHO: Geneva, 2005; 84 p. http:// www.who.int/vaccines/GIVS (accessed 3 October 2005).

9. WHO. Global measles and rubella strategic plan: 2012-2020. WHO, Geneva, 2012; 44 p. http://www.who.int/immunization.

10. Kubar' OI, Bichurina MA, Romanenkova NI, Asatryan AZH. Eticheskie principy likvidacii infekcij. Infekciya i immunitet. 2013; 3 (3): 205-212 p. Russian.

11. Kubar' OI, redaktor Etika infekcionnoj patologii. SPb: FBUN NIIEM imeni Pastera, 2014; 116 p. Russian.

12. Kubar' Ol, redaktor. Etika vakcinacii (kriterij nauchnogo i gumanitarnogo proryva). SPb: FBUN NIIEM imeni Pastera; 2018; 176 s. Russian.

13. Kubar OI, Bichurina MA, Romanenkova NI. Ethical Consideration Regarding COVID-19, EC Microbiology SI.02 2020; 14-15 p.

14. Ivanyushkin AYA. Vrachebnaya etika v Rossii (XIX - nachalo XX vv.). V knige: YUdin BG, redaktor. Bioetika: principy, pravila, problemy. M., 1998; 93-110 p. Russian.

15. Izbornik Velikogo knyazya Svyatoslava YAroslavicha i Svod yuridicheskih norm Kievskoj Rusi XI-HII vekov. CHteniya v obshchestve istorii drevnostej Rossii. 1882 oktyabr'-dekabr'; 4: 184.

16. Pravovoj status vrachevatelej Morskom Ustave Petra I HVIII veka. Polnoe sobranie Zakonov Rossijskoj Imperii s 1649 goda. SPb: 1830; 4 (1720-1722):11-12. Russian.

17. YUdin BG. Nacional'nye osobennosti stanovleniya bioetiki $\vee$ Rossii. V knige: Mishatkina TV, redaktor. Filosofiya biomedicinskih issledovanij. M., 2004; 71-90. Russian.

18. Bychkov IYA. K voprosu o zakonodatel'nom reglamentirovanii vrachebnyh eksperimentov nad lyud'mi. Sovetskij vrachebny] zhurnal, 1939; 1: 61-68 p. Russian.

19. Ugolovnaya otvetstvennost' vracha za vrachevanie bez soglasiya bol'nogo. SPb: 1904; 286 p. Russian.

20. Dmitriev BV. Sluchaj peresadki shchitovidnoj zhelezy i yuridicheskie voprosy, svyazannye s podobnymi peresadkami. Medicinskoe obozrenie, 1917; LXXXVII (13-16): 618-631. Russian.

21. O poryadke ispytaniya novyh medicinskih sredstv i metodov, mogushchih predstavit' opasnost' dlya zdorov'ya i zhizni bol'nyh. Postanovlenie byuro Uchenogo Medicinskogo Soveta ot 23 aprelya 1936 goda. Sbornik Postanovlenij. Narkomzdrav RSFSR. Uchenyj Medicinskij Sovet. M.: Izd. UMS; 1936; 1-4: 37-38. Russian.

22. Medunicyn NV. Vakcinoprofilaktika: prava cheloveka i interesy obshchestva. V knige: Pokrovskij VI. Lopuhin YUM, redaktory. Biomedicinskaya etika. M., Medicina, 1999; 58-68 p. Russian.

23. Convention on human rights and biomedicine. Council of Europe. European Treaty Series №164, Oviedo, 1997, 2004; 10 p.

24. CIOMS Guide to active vaccine safety surveillance. CIOMS, Geneva, 2017; 88 p. https://cioms.ch/publications/product/ cioms-guide-to-active-vaccine-safety-surveillance/

25. Guidelines for good clinical practice (GCP) for trials on pharmaceutical products. WHO, Geneva, 1995; 35 p. https:// www.who.int/medicines/publications/

26. International guidelines for ethical review of epidemiological studies. CIOMS, Geneva, 1991; 16 p. https://cioms.ch/ publications/product/1991-international-guidelines-for-ethicalreview-of-epidemiological-studies/

27. Operational guidelines for ethics committees that review Biomedical Research. WHO, Geneva, 2000; 39 p. https:// www.who.int/tdr/publications/training-guideline-publications/ operational-guidelines-ethics-biomedical-research

\section{Литература}

1. Кубарь О.И. Этические и правовые проблемы исследований на человеке: из истории России XX века. Журнал «Человек». 2001; 3: 115-122

2. Kubar O.I. Research involving human subjects: ethics and law in early $20^{\text {th }}$ century Russia, Bull. Med. Eth., 2001 October; 13-17 p.

3. International Declaration on Bioethics and Human Rights. UNESCO, Paris, 2005. http://www in. unesco.org.

4. International ethical guidelines for epidemiological studies. CIOMS, Geneva, 2009; 130 p. https://cioms.ch/publications/ product/international-ethical-guidelines-for-epidemiologicalstudies/.

5. International Ethical Guidelines for Health-related Research

Involving Humans - ClOMS, Geneva, 2016; 119 p. https:// cioms.ch/wp-content/uploads/2017/01/WEB-CIOMSEthicalGuidelines.pdf

6. Глобальная ликвидация полиомиелита. Отчет о пятом совещании Глобальной технической консультативной группь по ликвидации полиомиелита, Женева, 2000; 40 с.

7. Глобальный консультативный комитет по безопасности вакцин. Качество и безопасность вакцин, начиная от их разработки и до введения пациентам, Информационный бюллетень ВО3, 2005; 295 p. http://www.who. int/vaccine_ safety/committee/.

8. Global Immunization Vision and Strategy WHO: Geneva, 2005; 
84 p. http:// www.who.int/vaccines/GIVS (accessed 3 October 2005).

9. WHO. Global measles and rubella strategic plan: 2012-2020. WHO, Geneva, 2012; 44 p. http://www.who.int/immunization.

10. Кубарь О.И., Бичурина М.А., Романенкова Н.И., Асатрян А.Ж. Этические принципы ликвидации инфекций Инфекция и иммунитет. 2013; 3 (3): 205-212 с.

11. Кубарь О.И., редактор Этика инфекционной патологии. СПб: ФБУН НИИЭМ имени Пастера, 2014;116 с.

12. Кубарь О.И., редактор. Этика вакцинации (критерий научного и гуманитарного прорыва). СПб: ФБУН НИИЭМ имени Пастера; 2018; 176 с.

13. Kubar O.I., Bichurina M.A., Romanenkova N.I. Ethical Consideration Regarding COVID-19, EC Microbiology SI.02 2020; 14-15 p.

14. Иванюшкин А.Я. Врачебная этика в России (XIX - начало XX вв.). В книге: Юдин Б.Г., редактор. Биоэтика: принципы, правила, проблемы. М., 1998; 93-110 с.

15. Изборник Великого князя Святослава Ярославича и Свод юридических норм Киевской Руси XI-XII веков. Чтения в обществе истории древностей России. 1882 октябрьдекабрь; 4: 184.

16. Правовой статус врачевателей Морском Уставе Петра I XVIII века. Полное собрание Законов Российской Империи с 1649 года. СПб: 1830; 4 (1720-1722):11-12.

17. Юдин Б.Г. Национальные особенности становления биоэтики в России. В книге: Мишаткина Т.В., редактор. Философия биомедицинских исследований. М., 2004; 71-90.

18. Бычков И.Я. Квопросу озаконодательном регламентировании врачебных экспериментов над людьми. Советский врачебный журнал, 1939; 1: 61-68.
19. Уголовная ответственность врача за врачевание без согласия больного. СПб: 1904; 286 с.

20. Дмитриев Б.В. Случай пересадки щитовидной железы и юридические вопросы, связанные с подобными пересадками. Медицинское обозрение, 1917; LXXXVII (13-16): 618-631

21. О порядке испытания новых медицинских средств и методов, могущих представить опасность для здоровья и жизни больных. Постановление бюро Ученого Медицинского Совета от 23 апреля 1936 года. Сборник Постановлений. Наркомздрав РСФСР. Ученый Медицинский Совет. М.: Изд. УМС; 1936; 1-4: 37-38.

22. Медуницын Н.В. Вакцинопрофилактика: права человека и интересы общества. В книге: Покровский В.И. Лопухин Ю.М., редакторы. Биомедицинская этика. М., Медицина, 1999; 58$68 \mathrm{c.}$

23. Convention on human rights and biomedicine. Council of Europe. European Treaty Series №164, Oviedo, 1997, 2004; 10 p.

24. CIOMS Guide to active vaccine safety surveillance. CIOMS, Geneva, 2017; 88 p. https://cioms.ch/publications/product/ cioms-guide-to-active-vaccine-safety-surveillance/.

25. Guidelines for good clinical practice (GCP) for trials on pharmaceutical products. WHO, Geneva, 1995; 35 p. https:// www.who.int/medicines/publications/.

26. International guidelines for ethical review of epidemiological studies. CIOMS, Geneva, 1991; 16 p. https://cioms.ch/ publications/product/1991-international-guidelines-for-ethicalreview-of-epidemiological-studies/.

27. Operational guidelines for ethics committees that review Biomedical Research. WHO, Geneva, 2000; 39 p. https:// www.who.int/tdr/publications/training-guideline-publications/ operational-guidelines-ethics-biomedical-research. 


\title{
ETHICAL ASPECTS OF THE INFORMED CONSENT DURING COVID-19 VACCINATION
}

Zorin KV凶, Gurevich KG

A.I. Evdokimov Moscow State University of Medicine and Dentistry, Moscow, Russia

The main tactics used for COVID-19 prevention should be both quarantine measures and the large-scale vaccination of the population. This does raise many ethical issues related to obtaining informed consent in biomedical research and clinical practice. The full and adequate ethical review of vaccination against the novel coronavirus infection can be provided only subject to ethical aspects of voluntary informed consent. Without that, it would be impossible to control the quality, efficiency and safety of the vaccine, and, consequently, the patients' vaccination and its results.

Keywords: healthcare, medicine, biomedical ethics, voluntary informed consent, COVID-19.

Author contribution: Research concept and design - Gurevich KG; text writing and editing - Zorin KV.

$\triangle$ Correspondence should be addressed: Konstantin V. Zorin

st. Delegatskaya, 20, b. 1, Moscow, 127473; zkv1000@yandex.ru

Received: 01.03.2021 Accepted: 27.03.2021 Published online: 31.03.2021

DOI: $10.24075 /$ medet.2021.009

\section{ЭТИЧЕСКИЕ АСПЕКТЫ ДОБРОВОЛЬНОГО ИНФОРМИРОВАННОГО СОГЛАСИЯ ПРИ ВАКЦИНАЦИИ ПРОТИВ COVID-19}

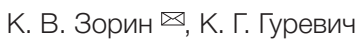

Московский государственный медико-стоматологический университет имени А.И. Евдокимова, Москва, Россия

\begin{abstract}
Основной тактикой профилактики COVID-19 должны быть не только карантинные мероприятия, но и масштабная вакцинация населения. Поэтому возникает множество этических вопросов, связанных с получением добровольного информированного согласия в биомедицинских исследованиях и клинической практике. Этическую экспертизу вакцинации против новой коронавирусной инфекции можно провести полноценно и адекватно лишь при условии соблюдения этических аспектов добровольного информированного согласия. Без этого нельзя проконтролировать качество, эффективность и безопасность вакцины, а, следовательно, вакцинации пациентов и ее результаты.
\end{abstract}

Ключевые слова: здравоохранение, медицина, биомедицинская этика, добровольное информированное согласие, COVID-19.

Вклад авторов: Концепция и дизайн исследования - Гуревич К. Г.; написание и редактирование текста - Зорин К. В.

$\triangle$ Для корреспонденции: Зорин Константин Вячеславович

ул. Делегатская, д. 20, стр. 1, г. Москва; 127473; zkv1000@yandex.ru

Статья получена: 01.03.2021 Статья принята к печати: 27.03.2021 Опубликована онлайн: 31.03.2021

DOI: $10.24075 /$ medet.2021.009

\section{Introduction}

In March 2020 the WHO reported on the new global pandemic of COVID-19 [1]. To date, the pandemic has affected most countries in the world and almost all constituent entities of the Russian Federation. In addition to restrictions on freedom of movement, quarantine measures cause considerable economic damage, especially to small and medium-sized enterprises, and result in economic downturn and rising unemployment $[2,3]$. People fall out of the real economy in some way due to self-isolation. The basket of goods is changing, and there is a growing demand for personal protective equipment and hygiene items. The costs to the health system are increasing [4]. The decline in tourism, transport industry, and entertainment industry is evident. In some instances, social stress and psychological discomfort are responsible for people's failure to comply with the quarantine regime [5]. Some people easily fall into panic [6].

That is why the main tactics used for prevention of the novel coronavirus infection should be both quarantine measures and the large-scale vaccination of the population. However, people experience difficulties with navigation in the flow of information, as well as with selection of reliable information, including information on developing, testing, and applying the vaccines. This does raise many ethical issues related to obtaining informed consent in biomedical research and clinical practice.

\section{RESULTS AND DISCUSSION}

The legislative framework for the ethical reviews during development, testing, and using the vaccines, is provided for by the Constitution of the Russian Federation (passed by popular vote on December 12, 1993, with modifications adopted in the course of all-Russia voting on July 1, 2020). Part 3 of the Article 55 stipulates:

"1. The listing in the Constitution of the Russian Federation of the fundamental rights and freedoms shall not be interpreted as a rejection or derogation of other universally recognized human rights and freedoms.

2. In the Russian Federation no laws shall be adopted cancelling or derogating human rights and freedoms.

3. The rights and freedoms of man and citizen may be limited by federal law only to the extent necessary for the protection of the fundamental principles of the constitutional system, morality, health, the rights and lawful interests of other people, for ensuring defence of the country and security of the State" [7].

The legislative framework for ethical reviews of vaccine testing and use in the Russian Federation is also regulated by federal laws and regulations, as well as by the orders of the Government and the Ministry of Health, and by recommendations of Rospotrebnadzor.

From an ethical point of view, preventive vaccination usually entails the need to resolve the conflict of interest. It is known 
that during the development and testing of new vaccines, the two matters, often contradictory, are to be resolved:

1) obtaining credible evidence of the vaccine efficiency and safety;

2) protecting health and lives of the clinical trial participants.

Currently, the ethical aspects of the vaccines against the novel coronavirus infection clinical trials are under active discussion both in Russia and worldwide. Getting comprehensive and reliable scientific information about such vaccine efficiency and safety goes hand-in-hand with the need for adherence to fundamental ethical principles and standardization of ethical reviewing of vaccine clinical trials. This is a mandatory requirement for the new drug registration and manufacturing.

There are some additional risk factors, which make this process more difficult. Vaccination can potentially involve much of the world's population (up 70\% of the population), which, in fact, gives the researchers no room for error. There is also some fair criticism, and founded complaint from vaccine refusers. It is an impermissible miscalculation to ignore their vision.

Mandatory compulsory vaccination is a crucial social and political issue that affects public life, economy, and finances of all countries. Furthermore, safety standards and ethical review issues, set out during the vaccine clinical trials, are usually more complex than those set out during investigation of other medications. These features underlie the multi-layered nature of the conflict of interest, and require development of the legal and ethical framework, as well as appropriate training of members and experts of the Ethics Committees of different countries.

The first international instrument, outlining the ethical principles of clinical trials involving human subjects, is the Belmont Report, introduced by the National Commission for the Protection of Human Subjects of Biomedical and Behavioral Research [8]. The report identifies three basic ethical principles:

- The principle of respect for persons calls for voluntary participation in the vaccine testing. To this end, potential participants or their legal representatives should be provided all the necessary information about the trial, and should make an informed decision. The researchers shall obtain the participants' written consent prior to experiment.

- The principle of beneficence implies two rules: do not harm, maximize possible benefits and minimize possible harms. Hence the need for assessing the balance between benefits and risks. In certain cases, participation in the clinical experiments can contribute to the increased risk of the disorder in the future or produce the immune response not strong enough.

- The principle of justice (fairness in distribution): the benefits and burdens of research participation should be fairly distributed among all groups involved, irrespective of age, gender, location, ethnic or racial background, etc. The potentially vulnerable groups of experimental subjects are identified, for example, individuals fostering an excessive sensitivity to the harmful effects (pregnant women, elderly people, disabled persons), individuals incapable of giving informed consent (children, mentally disabled people), and individuals, whose informed consent could be called into question (military personnel, migrants, prisoners).

The Council for International Organizations of Medical Sciences, together with the World Health Organization, defines the concept of vulnerability as the relative (or absolute) incapability of protecting the person's own interests. Vulnerable groups are those having an increased likelihood of being wronged or of incurring additional harm, often abused by those who have a capacity to harm [9].

The informed consent given on a voluntary basis is a basic guarantee of the rights, and respect for the dignity of any biomedical research participant. In order to maintain the benefit-risk balance, the information provided should include the description of all benefits and risks related to research participation, alternative protection methods, medical and social consequences of participation and refusal to participate, insurance and state guarantees, etc. The essential principle of the new vaccine trial ethical review is protecting the confidentiality of participants' information and experimental results.

In fact, the informed consent is an informed decision concerning the proposed treatment option made by competent patient on a voluntary basis based on the full, objective and comprehensive information about the forthcoming treatment, possible complications and alternative treatment options [10, 11].

This process stresses the ethical value of the patient's participation and personal autonomy. It is necessary to explain the interventions of certain protocol to potential participant, teach him about his rights as a clinical trial participant, explain the essence of the studied scientific question, the experimental method, as well as the trial potential benefits and risks. The procedure must be thoroughly recorded [12, 13].

The Ministry of Health of the Russian Federation (the letter dated December 9, 2020, № 17-0/u/2-18965, and the letter dated January 15, 2021, № 1/M/1-155) has issued the Standard Operating Procedure "The procedure for COVID-19 vaccination in adults" [14, 15]. The first officially registered GamCOVID-Vac vaccine is to be used, the combined vector vaccine for prevention of coronavirus infection caused by SARS-CoV-2.

Annex № 5 is referred to as "Informed consent to vaccination or refusal of vaccination" [16]. Having signed that document, the patient demonstrates that the physician has informed his/ her about the following:

1) preventive vaccination involves administration of immunobiological medicinal product in order to generate the specific unresponsiveness to novel coronavirus infection (COVID-19) in adults. The vaccine employs biotechnological methods, which do not use the SARS-CoV-2 virus pathogenic for humans. The medicinal product consists of two components;

2) the need to perform preventive vaccination in two phases and contraindications to vaccination;

3) possible post-vaccination reactions: systemic (shortterm flu-like syndrome, characterized by fever, arthralgia, myalgia, asthenia, general feeling of malaise, headache), and local (soreness around the injection site, hyperemia, swelling), which can occur during days 1-2 after vaccination and resolve during the next three days;

4) compulsory medical examination before each stage of vaccination (medical survey if required);

5) compliance with the prescriptions of medical professionals.

Then, the document declares, that the patient was provided an opportunity to ask any question and received a full reply, which was properly understood. That is indicative of the informed consent to vaccination (in this case, using GamCOVID-Vac, the combined vector vaccine for prevention of coronavirus infection caused by SARS-CoV-2).

\section{CONCLUSION}

Ethical review of vaccination against the novel coronavirus infection entails improving preventive immunization and general achievements of scientific and technological progress. Such full and adequate ethical review can be provided only subject to ethical aspects of voluntary informed consent. Without that, it would be impossible to control the quality, efficiency and safety of the vaccine, and, consequently, the patients' vaccination and its results. 
1. WHO. Coronavirus disease (COVID-19) Pandemic. Access mode: https://www.who.int/emergencies/diseases/novel-coronavirus-2019 [date of access: 02.02.2021].

2. Pasquini-Descomps $\mathrm{H}$, Brender $\mathrm{N}$, Maradan D. Value for Money in H1N1 Influenza: A Systematic Review of the Cost-Effectiveness of Pandemic Interventions. Value Health. 2017 Jun; 20(6):819827. DOI: 10.1016/j.jval.2016.05.005. Epub 2016 Jun 29.

3. Kinross P, Suetens C, Gomes Dias J, Alexakis L, Wijermans A Colzani E, Monnet DL. Rapidly increasing cumulative incidence of coronavirus disease (COVID-19) in the European Union / European Economic Area and the United Kingdom, 1 January to 15 March 2020. European Centre For Disease Prevention And Control Ecdc Public Health Emergency Team // Euro Surveil. 2020 Mar; 25(11). DOI: 10.2807/1560-7917.ES.2020.25.11.2000285. Epub 2020 Mar 16

4. Ayittey FK, Ayittey MK, Chiwero NB, Kamasah JS, Dzuvor C. Economic impacts of Wuhan 2019-nCoV on China and the world. J Med Virol. 2020 May; 92(5):473-475. DOI: 10.1002/jmv.25706. Epub 2020 Feb 18.

5. Merchant RM, Lurie N. Social Media and Emergency Preparedness in Response to Novel Coronavirus. JAMA. 2020 Mar 23. DOI: 10.1001/jama.2020.4469. [Epub ahead of print]

6. Shimizu K. 2019-nCoV, fake news and racism. Lancet. 2020. Feb 29;395(10225):685-686. DOI: 10.1016/S0140-6736(20)303573. Epub 2020 Feb 11.

7. The Constitution of the Russian Federation (adopted by popular vote on 12.12.1993 with amendments approved during a nationwide vote on 01.07.2020). Access mode: https://rg.ru/2020/07/04/ konstituciya-site-dok.html [date of access: 02.02.2021]. Russian.

8. National Commission for the Protection of Human Subjects of Biomedical and Behavioral Research (1979). Department of Health, Education and Welfare (DHEW). The Belmont

\section{Литература}

1. WHO. Coronavirus disease (COVID-19) Pandemic. Режим доступа: https://www.who.int/emergencies/diseases/novelcoronavirus-2019[дата обращения: 02.02.2021].

2. Pasquini-Descomps $\mathrm{H}$, Brender N, Maradan D. Value for Money in H1N1 Influenza: A Systematic Review of the Cost-Effectiveness of Pandemic Interventions. Value Health. 2017 Jun; 20(6):819827. DOI: 10.1016/j.jval.2016.05.005. Epub 2016 Jun 29.

3. Kinross P, Suetens C, Gomes Dias J, Alexakis L, Wijermans A, Colzani E, Monnet DL. Rapidly increasing cumulative incidence of coronavirus disease (COVID-19) in the European Union / European Economic Area and the United Kingdom, 1 January to 15 March 2020. European Centre For Disease Prevention And Control Ecdc Public Health Emergency Team. Euro Surveil. 2020 Mar; 25(11). DOI: 10.2807/1560-7917.ES.2020.25.11.2000285. Epub 2020 Mar 16

4. Ayittey FK, Ayittey MK, Chiwero NB, Kamasah JS, Dzuvor C. Economic impacts of Wuhan 2019-nCoV on China and the world. J Med Virol. 2020 May; 92(5):473-475. DOI: 10.1002/jmv.25706. Epub 2020 Feb 18

5. Merchant RM, Lurie N. Social Media and Emergency Preparedness in Response to Novel Coronavirus. JAMA. 2020 Mar 23. DOI: 10.1001/jama.2020.4469. [Epub ahead of print]

6. Shimizu K. 2019-nCoV, fake news and racism. Lancet. 2020. Feb 29;395(10225):685-686. DOI: 10.1016/S0140-6736(20)303573. Epub 2020 Feb 11.

7. Конституция Российской Федерации (принята всенародным голосованием 12.12.1993 с изменениями, одобренными в ходе общероссийского голосования 01.07.2020). Режим доступа: https://rg.ru/2020/07/04/konstituciya-site-dok.html [дата обращения: 02.02.2021].

8. National Commission for the Protection of Human Subjects of Biomedical and Behavioral Research (1979). Department of Health, Education and Welfare (DHEW). The Belmont

9. International Ethical Guidelines for Biomedical Research Involving
9. International Ethical Guidelines for Biomedical Research Involving Human Subjects. Geneva: CIOMS, 2002; 60 p.

10. Research Involving Persons with Mental Disorders that May Affect Decisionmaking Capacity, Vol 1, Report and Recommendations of the National Bioethics Advisory Commission. Rockville, MD: National Bioethics Advisory Commission (NBAC), 1998; 176 p.

11. Research Involving Persons with Mental Disorders that May Affect Decisionmaking Capacity, Vol 2, Commissioned Papers by the National Bioethics Advisory Commission. Rockville, MD: National Bioethics Advisory Commission (NBAC), 1999.;79 p.

12. Semenova NV. The informed consent and borders of autonomy in clinical trials with participation of vulnerable groups of patients. Medical ethics. 2018;1:63-65. Russian.

13. Semenova NV, Yanushko MG, Yakovleva YA. Ethical issues of the informed consent procedure in schizophrenia patients in view of cognitive dysfunction. V.M. Bekhterev Review of psychiatry and medical psychology. 2018;4:108-116. Russian.

14. Letter of the Ministry of Health of Russia dated December 9 2020 №. 17-o / and / 2-18965 «On the procedure for vaccination against COVID-19 in the adult population». Access mode: https:// sudact.ru/law/pismo-minzdrava-rossii-ot-09122020-n-17oi2-18965/ [date of access: 02.02.2021]. Russian.

15. Letter of the Ministry of Health of the Russian Federation dated January 15, 2021 № 1 / I / 1-155 on the standard operating procedure «Procedure for vaccination against COVID-19 in the adult population». Access mode:https://www.garant.ru/products/ ipo/prime/doc/400115759/ [date of access: 02.02.2021]. Russian.

16. Appendix № 5 «Voluntary informed consent to vaccination or refusal from it». Access mode: https://sudact.ru/law/pismo-minzdravarossii-ot-09122020-n-17-oi2-18965/prilozhenie/prilozhenie-n-5/ [date of access: 02.02.2021]. Russian.

Human Subjects. Geneva: CIOMS, 2002; 60 p.

10. Research Involving Persons with Mental Disorders that May Affect Decisionmaking Capacity, Vol 1, Report and Recommendations of the National Bioethics Advisory Commission. Rockville, MD: National Bioethics Advisory Commission (NBAC), 1998; 176 p.

11. Research Involving Persons with Mental Disorders that May Affect Decisionmaking Capacity, Vol 2, Commissioned Papers by the National Bioethics Advisory Commission. Rockville, MD: National Bioethics Advisory Commission (NBAC), 1999.;79 p.

12. Семенова Н.В. Информированное согласие и границы автономии в клинических исследованиях с участием уязвимых групп пациентов. Медицинская этика. 2018; 1: 63-65.

13. Семенова Н.В., Янушко М.Г., Яковлева Ю.А. Этические проблемы информированного добровольного согласия у больных шизофренией в связи с особенностями их когнитивного функционирования. Обозрение психиатрии и медицинской психологии имени В.М. Бехтерева. 2018; 4: 108-116.

14. Письмо Министерства здравоохранения РФ от 9 декабря 2020 г. № 17-о/и/2-18965 «О порядке проведения вакцинации против COVID-19 взрослому населению». Режим доступа: https://sudact.ru/law/pismo-minzdrava-rossii-ot-09122020-n17-оi2-18965/ [дата обращения: 02.02.2021].

15. Письмо Министерства здравоохранения РФ от 15 января 2021 г. № 1/M/1-155 о стандартной операционной процедуре «Порядок проведения вакцинации против COVID-19 взрослому населению». Режим доступа: https://www.garant. ru/products/ipo/prime/doc/400115759/ [дата обращения: 02.02.2021].

16. Приложение № 5 «Добровольное информированное согласие на проведение вакцинации или отказ от нее». Режим доступа: https://sudact.ru/law/pismo-minzdrava-rossii-ot-09122020-n17-oi2-18965/prilozhenie/prilozhenie-n-5/ [дата обращения: 02.02.2021]. 


\title{
EDUCATING RELATIVES OF ICU PATIENTS FOR BETTER COMPLIANCE: OUR EXPERIENCE
}

Saetgaraev $\mathrm{AK}^{1,2}$, Maximov IL ${ }^{1}$, Guryleva ME', Grigoreva IA ${ }^{1} \otimes$

Kazan State Medical University of the ministry of health of Russia, Kazan, Russia

2 Tatarstan Cancer Center, Kazan, Russia

To reduce the risk of postoperative complications among elderly and senile patients, intensive care units can engage patients' family members in delivering bedside care and assisting in their rehabilitation after completing a nurse skills training course. The aim of this study was to analyze the legal and ethical framework pertaining to ICU organizational practices, survey the family members of ICU patients and develop a nurse skills training course for family members at the Clinic for Anesthesiology and Intensive Care of Tatarstan Clinical Cancer Center. We analyzed ICU regulations and surveyed 35 family members of ICU patients using a specially designed questionnaire. In 2017-2019, 185 individuals took the proposed training course; 32 ICU patients received additional care from their trained relatives. The mental state of the patients was assessed on the Mini Mental State scale; their physical condition was also assessed (the presence of bedsores, enteral nutrition). $71 \%$ of the respondents accept the restrictive policies of ICU, $97 \%$ believe they are ready to take care of their family member in ICU, $66 \%$ do not have the necessary experience. A 3-h long interactive training course was designed to teach family members nursing skills. A total of 185 volunteers completed the training course, and $32 \mathrm{ICU}$ patients received additional care from their trained relatives. As a result, the quality of their enteral nutrition, skin condition and mental state improved. Engagement of trained family members in the care and rehabilitation of ICU patients creates a friendly atmosphere and promotes positive changes to the patient's condition, their emotional and cognitive state.

Keywords: bedsores, rehabilitation, rehabilitation period, elderly and senile age, trained and trained relatives of the patient

Author contribution: Saetgaraev AK — organization of school work, work with patients and their relatives, their physical examination, analysis of medical literature; Maksimov IL — research idea, legal advice to patients and their relatives on care issues, analysis of regulatory legal acts; Guryleva ME - ethical support of the work carried out, consulting on the conduct of clinical trials and statistical calculations, writing a text; Grigorieva IA — conducting a sociological survey, collecting materials, creating tables and describing them.

$\triangle$ Correspondence should be addressed: Iraida A. Grigoreva Butlerova St., 49, Kazan, 420012; giagr@yandex.ru

Received: 15.03.2021 Accepted: 25.03.2021 Published online: 30.03.2021

DOI: $10.24075 /$ medet.2021.003

\section{ОПЫТ РАБОТЫ С ПАЦИЕНТАМИ РЕАНИМАЦИОННОГО ОТДЕЛЕНИЯ И ИХ РОДСТВЕННИКАМИ ПО ИНФОРМИРОВАНИЮ И ОПТИМИЗАЦИИ КОМПЛАЙНСА}

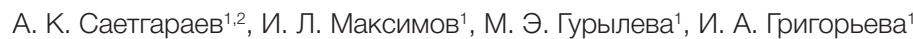 \\ 1 Казанский государственный медицинский университет Минздрава России, Казань, Россия \\ 2 Республиканский клинический онкологический диспансер МЗ РТ, г. Казань, Россия
}

\begin{abstract}
Актуальность проблемы: для снижения риска развития послеоперационных осложнений у пациентов пожилого и старческого возраста ОАРИТ предложено привлекать к уходу и ранней реабилитации подготовленных и информированных родственников. Целью работы явился анализ источников этико-правового регулирования работы ОАРИТ, социологический опрос родственников пациентов и разработка образовательной программы для их обучения на базе клиники анестезиологии и интенсивной терапии РКОД МЗ РТ. Материалы и методы. Изучена правовая база работы ОАРИТ в РФ, проведено анкетирование 35 родственников пациентов ОАРИТ по специально разработанной анкете. В 2017-2019 гг. обучено 185 волонтеровродственников, 32 пациента получили их дополнительный уход, после чего был оценен психический статус больных (шкала Mini Mental State) и физическое состояние (наличие пролежней, энтеральное питание). Полученные результаты: $71 \%$ респондентов с пониманием относятся к ограничениям по общению с больным в ОАРИТ, 97\% считают себя готовыми к участию в уходе за больным родственником, но не имеют такого опыта 66\%. Поэтому для них была разработана и апробирована 3-х часовая интерактивная программа обучения. Было обучено 185 волонтеров, к уходу за 32 пациентами допущены их обученные родственники. Предварительные результаты: улучшение энтерального питания, состояния кожных покровов и психического статуса больных. Вывод: предложенная система привлечения волонтеров из числа родственников пациентов ОАРИТ для ухода и реабилитации больных создает доброжелательную атмосферу, обеспечивает положительную динамику физических и когнитивно-эмоциональных нарушений.
\end{abstract}

Ключевые слова: пролежни, реабилитация, реабилитационный период, пожилой и старческий возраст, подготовленные и обученные родственники пациента

Вклад авторов: Саетгараев А. К. - организация работы школы, работа с пациентами и их родственниками, их физикальный осмотр, анализ медицинской литературы; Максимов И. Л. - идея исследования, юридическое консультирование пациентов и их родственников по вопросам ухода, анализ нормативно-правовых актов; Гурылева М. Э. - этическое сопровождение проводимой работы, консультирование по вопросам проведения клинических исследований и статистическим расчетам, написание текста; Григорьева И. А. — проведение социологического опроса, сбор материалов, формирование таблиц и их описание.

$\varangle$ Для корреспонденции: Григорьева Ираида Андреевна ул. Бутлерова, д. 49, г. Казань, 420012; giagr@yandex.ru

Статья получена: 15.03.2021 Статья принята к печати: 25.03.2021 Опубликована онлайн: 30.03.2021

DOI: $10.24075 /$ medet.2021.003

Introduction. Today the state is investing increasingly in the construction of new hospitals, upgrading medical equipment, standardizing medical care, improving medical education, and transitioning to P4 medicine. However, it may still be challenging for the physician to establish an ethically and legally ideal relationship with their patient, the patient's family members or legal representatives, especially if the disease has a profound societal impact or the patient comes from a vulnerable social group.

Communication between society members is regulated by ethics and law. In Russia, the doctor-patient relationship has been traditionally and legislatively paternalistic. Only healthcare workers had access to intensive care units, and what was happening behind closed doors never went public [1]. 
This study analyzes the existing ethical and legal framework for intensive care units (ICU) at Russian healthcare facilities and the possibility of refining it by pursuing the policy of transparency and engagement of family members in the bedside care and early rehabilitation of postoperative ICU patients.

Legal issues. Since the transformation of Russia into a rule-of-law-based state was declared and the law on the Fundamentals of Healthcare Legislation was passed in 1993 [2], a lot has changed in the legislation, but not in the mentality of the Russian population. The Federal Law № 323 on the Fundamental Principles of Public Health Protection passed in 2011 articulates the rights of the patient, including the right to receive full information about their health, provide informed consent to a medical intervention and have visitors while being in hospital, given that the current epidemiological situation is favorable [3].

However, up to this day the tradition remains strong, and it is only medical personnel who have access to patients in $I C U$, although time dictates the need for a different approach. In 2018, the Committee on Public Health Protection ratified a number of amendments to the Law 323, allowing visits to ICU patients from their close relatives. The Committee recommended that the State Duma adopt the amendments in the first reading [4].

Similar to any other law, the law 323 defines the rights of the patient but does not describe how these rights should be implemented. Implementation is regulated by secondary legislation, i.e. rules established by local healthcare facilities that determine how the visit must be organized.

After a barrage of complaints to the President, the Russian Ministry of Healthcare issued an explanatory document (Information Letter) in 2016 [5] clarifying visitation policies for family members of ICU patients and accompanied it with an information leaflet for visitors, which they are expected to read before the visit. Being a list of recommendations, the Letter is not legally binding. However, it specifies

- who can visit an ICU patient (family members, including the parents, spouse, and adult children); visitors who are not related to the patient are allowed into ICU only if accompanied by a close relative of the patient; no more than 2 people at a time are allowed in the ward;

- visitor's age (above 14 years),

- time of visit is specified indirectly (no visits are allowed during invasive manipulations, like intubation, vascular catheter placement, dressing change, cardiopulmonary resuscitation, etc.),

- the visitor is expected to take off their outermost clothes and don an isolation gown, a surgical mask and a cap; shoe covers must be worn; the visitor must wash their hands before entering the ward;

- mobile phones and other electronic devices must be turned off;

- the visitor is expected to be quiet and compliant, stay away from medical equipment and refrain from obstructing care delivered to other patients.

The duration of the visit is not specified, although the Letter implies the engagement of family members in patient care (they can voluntarily assist in bedside procedures and keep the ward clean after being instructed by ICU personnel).

The Letter highlights the importance of epidemiological safety: visitors cannot enter ICU if they have symptoms of acute infection (fever, signs of respiratory infection, diarrhea). No medical documents confirming the absence of disease are required. This does not contradict but instead complements the Order No. 44 signed by the Chief Public Health Officer on December 24, 2020, which ratifies sanitary requirements 2.1.3678-20 (Sanitary and Epidemiological Requirements for Buildings, Premises, Facilities, Equipment, Transport Vehicles, and Businesses involved in the Selling of Goods, Providing Services or Conducting Works) and allows visits to ICU if the visitor does not obstruct therapeutic or diagnostic manipulations, make the hospital stay distressing for the patient or pose a threat to occupational safety of healthcare workers [6].

In order to harmonize local legislation with the Federal Law 323 and clarify some of its provisions, the Russian Ministry of Healthcare issued Order 869n on August 19, 2020, which established general hospital visitation policies for the family members of ICU patients; the order has been registered with the Ministry of Justice but has not taken effect yet [7].

Unfortunately, this Order does not regulate every aspect of visitation (the possibility of visiting an ICU patient in a TB hospital or a closed medical institution, time and duration of visits, etc.). At the same time, the Order gives the physician an exclusive right to make decision about allowing or prohibiting access to ICU to family members of friends if the patient is unable to give informed consent. The Order $1177 \mathrm{n}$ of the Ministry of Healthcare dated December 20, 2012 establishes the Procedure of Giving Informed Consent to or Refusing a Medical Intervention for Certain Types of Interventions, Forms of Informed Consent and Forms of Refusing a Medical Intervention [8] and requires healthcare workers (attending physicians) to obtain voluntary informed consent from the patient (if the patient is able to articulate their will) to the disclosure of information about their health to their legal representatives of any other chosen individuals in writing; other options are not specified in the Order.

\section{Ethical issues}

Today, there are 2 effective models of doctor-patient relationship. The first is based on the paternalistic approach and the passive role of the patient. This approach normally applies to elderly or emergency patients. The second approach is based on the cooperation between the doctor and the patient. It is usually supported by young and middle-aged patients, at the prehospitalization stage, or in the case of planned admission [9]. In the first model, informed consent signed by the patient is a mere formality, because most elderly or emergency patients do not read the informed consent form and do not ask questions about it, although according to the current legislation [3] informed consent is mandatory and must be obtained before any medical intervention; healthcare providers must comply with this mandate in order to keep their license. Informed consent forms were designed by the Ministry of Healthcare and provide valid and comprehensive information about the intervention. At the same time, according to a research team from Perm, only one-third (33\%) of patients admitted to the City Hospital understood what a voluntary informed consent was; $27 \%$ thought it was not mandatory, and only $21 \%$ could recall what the form said. Among the respondents receiving therapeutic injections, 3\% thought they had not given their consent to injections, and of those who had, $85 \%$ did not know what medications they were receiving [10]. This suggests that the bioethical model has failed to become the leading model in the Russian public healthcare system and a lot is to be done to educate our patients about the legal and ethical aspects of medical care.

On the other hand, the medical community understands that the paternalistic approach to treatment has no future, 
Table 1. Age of respondents (family members to take care of their relative in ICU)

\begin{tabular}{|c|c|c|}
\hline Age & Number of respondents & 17,1\% \\
\hline $25-35$ years & 6 & $11,4 \%$ \\
\hline $35-45$ years & 4 & $17,1 \%$ \\
\hline $45-55$ years & 6 & $45,7 \%$ \\
\hline $55-65$ years & 16 & $8,6 \%$ \\
\hline above 65 years & 3 & \multicolumn{2}{|c|}{} \\
\hline
\end{tabular}

especially when it comes to ICU, and focuses on critical care, emphasizing the positive international experience of the open, family-centered approach to patient care. Family engagement in intensive care at the early postoperative period significantly improves treatment outcomes [11].

Thus, despite the Federal Law 323 and some other normative documents, not every aspect of doctor-patient communication is regulated by the current legislation. This encouraged us to characterize the need and willingness to overcome the existing tradition of doctor-family (legal representative) relationship and engage the family in postoperative patient care in ICU. We were also motivated by the international experience of engaging family members in the rehabilitation of ICU patients $[12,13,14]$.

The aim of this study was to understand the willingness and preparedness of families to participate in the medical care and rehabilitation of ICU patients, evaluate their knowledge of postoperative patient care and develop a training course for family members in order to teach them skills and psychologic tolerance needed to care for ICU patients at the Clinic for Anesthesiology and Intensive Care (Tatarstan Clinical Cancer Center).

\section{Methods}

Thirty-five relatives of patients transferred to the ICU of Tatarstan Clinical Cancer Center were surveyed (Tables 1-3)

The following degrees of kinship to our ICU patients were identified: father (17.1\%), mother (14.3\%), daughter (5.7\%), sister $(8.6 \%)$, spouse (28.6\%), other relative (25.7\%). Thus, patients in ICU were mostly visited by their spouse, parents and other close relatives.

The study found that $71.4 \%$ of the respondents accepted the restrictive visitation policy; $20 \%$ thought radical changes were needed and relatives should be given access to ICU, similar to other hospital departments; $8.6 \%$ had never thought about it.

All the respondents (100\%) were very concerned about their critically ill relatives, phoned the doctor repeatedly to find out about the condition of the patient and were ready to visit the patient in ICU any time.

Of all the respondents, $97.1 \%$ believed they were ready to take care of the patient in ICU, and only $2.9 \%$ were not sure about it.

Visits were considered a great physical and psychological support for the patient by $85.7 \%$ of the respondents; $8.6 \%$ thought the opposite (they were worried about distracting ICU personnel); $5.7 \%$ reported they had never thought about it.

No previous experience of caring for a critically ill patient was reported by $65.7 \%$ of the respondents.
The quality of medical care in ICU was assessed as quite high by most of the respondents (high: 18.6\%; good: 52.9\%; no negative feedback was reported); the openness and willingness of the medical personnel to communicate with family members was also appreciated (high: 27.1\%; good: 50\%; no negative feedback was obtained). The majority (60\%) of the respondents did not know what rights the patient is entitled to and could not name them without a prompt. According to the respondents, the patient has the right to know the diagnosis, the right to be taken care of by a family member, the right for medical care in general, constitutional rights, the right for a clean bed and good care, the right to have a second pair of shoes, the right for meals, the right for a friendly attitude, the right to choose a doctor, the right for confidentiality, and the right to use a mobile phone.

Having analyzed the completed questionnaires, we concluded that despite the vast legal framework, most of the respondents (relatively young people with a university degree) did not know about patient rights. They felt they were responsible for the patient (100\%), most of them (97.1\%) were willing to visit the patient in ICU and engage in bedside care, although only one-third (34.3\%) of the respondents had the necessary skills and experience. The respondents assessed the quality of patient care delivered by the medical personnel as high; they also appreciated the willingness of the healthcare workers to cooperate with the relatives. Therefore, we concluded that a training course for family members could be organized to teach them skills needed to perform bedside care of critically ill patients and that trained family members could be engaged in bedside care in ICU under the guidance of ICU personnel. A decision was made to try this model at the Clinic for Anesthesiology and Intensive Care.

We developed the criteria for selecting family members who were willing to participate in the medical care and early rehabilitation of ICU patients and designed a training course to teach them patient care skills. Selection was based on the results of interviews with family members. The following eligibility criteria were applied:

- being cooperative but not obtrusive;

- being adequate: understand the leading role of ICU staff and strictly follow their instructions; understand their responsibility for the patient; admit that there are no perfect treatments and outcomes may be negative.

- being smart (understand the applied therapeutic technique, assess the situation and how it may progress);

- being tactful.

The training course was 180 min long and consisted of 3 steps (30 min each):

Step I was conducted by the head of ICU and the chief

Table 2. Sex of respondents (family members to take care of their relative in ICU)

\begin{tabular}{|c|c|c|}
\hline Sex & Number of respondents & $\%$ \\
\hline Male & 10 & $28,6 \%$ \\
\hline Female & 25 & $71,4 \%$ \\
\hline
\end{tabular}


Table 3. Education of respondents (family members to take care of their relative in ICU)

\begin{tabular}{|c|c|c|}
\hline Education & Number of respondents & $\%$ \\
\hline Higher & 17 & $48,6 \%$ \\
\hline Secondary & 10 & $28,6 \%$ \\
\hline College & 5 & $14,3 \%$ \\
\hline N/A & 3 & $8,6 \%$ \\
\hline
\end{tabular}

nurse and covered the following theoretical problems:

- legal and organizational issues;

- sanitary and epidemiological requirements for working in ICU;

- general information about anesthesia and pain relief; body and mouth cavity anatomy;

- asepsis and antisepsis;

- nutrition in the perioperative period;

- bedsore prevention and respiratory exercise;

- emotional and cognitive characteristics of ICU patients; measures for psychological support.

This information was provided in plain words, without unnecessary scientific terms, using illustrations, presentations and educational films.

In step II, the chief nurse was joined by a resuscitationist. The group was taught bedsore prevention measures. For that, a life size nursing skills manikin was used. Mouth hygiene was explained using a head training manikin.

In step III, the trainees were allowed into ICU, where they practiced the acquired skills on their ill relatives under the guidance of the chief nurse.

From 2017 to 2019, 185 family members of ICU patients took the training course. The training was interactive and involved the use of medical simulators, guidebooks and other materials.

After completing the training course, the trainees were allowed to perform bedside care on 32 postoperative ICU patients. This resulted in improved enteral nutrition (the volume of the consumed enteral mixture) and improved serum albumin dynamics (albumin is a universal serum marker of malnutrition) [16]. Bedsores were few [15] and mild; this was associated with good skin care. The patients' mental state was assessed using the Mini Mental State (MMS) scale on days 1-6 days following surgery; the scores indicated positive dynamics.

\section{References}

1. Zakon «Ob utverzhdenii osnov zakonodatel'stva Soyuza SSR soyuznykh respublik o zdravookhranenii» ot 19 dekabrya 1969 goda (s izm. i dop., vnesennymi Ukazami Prezidiuma VS SSSR ot 18.06.1979 - Vedomosti VS SSSR, 1979, N 25, st. 438; ot 26.03.1984 - Vedomosti VS SSSR, 1984, N 13, st. 188; ot 08.06.1984 - Vedomosti VS SSSR, 1984, N 24, st. 422; Zakonom SSSR ot 27.11.1985 - Vedomosti VS SSSR, 1985, N 48, st. 919; Ukazom Prezidiuma VS SSSR ot 25.08.1987 Vedomosti VS SSSR, 1987, N 34, st. 560; Zakonami SSSR ot 23.04.1990 - Vedomosti SND i VS SSSR, 1990, N 19, st. 326; ot 22.05.1990 - Vedomosti SND i VS SSSR, 1990, N 23, st. 422. Biblioteka normativno-pravovykh aktov Soyuza Sovetskikh Sotsialisticheskikh Respublik. Russian. http://www.libussr.ru/ doc_ussr/usr_7212.htm/. Russian.

2. Federal'nyy zakon "Osnovy zakonodatel'stva Rossiyskoy Federatsii ob okhrane zdorov'ya grazhdan» (utv. VS RF 22.07.1993 N 5487-1) (red. ot 07.12.2011) Russian. Spravochnaya sistema «Konsul'tant Plyus». Versiya Prof. http://www.consultant.ru/ document/cons_doc_LAW_2413/ Russian.
During the COVID-19 pandemic we had to shut down the project, but its positive outcomes are prompting us to initiate an open prospective study to look into the efficacy of care and rehabilitation of ICU patients performed by their trained family members and compare it with the traditional rehabilitation model of ICU patients; this will allow us to implement the analogue of the nurse-led family support intervention in Intensive Care Units [17] I our clinic and perhaps promulgate our experience to wider audiences.

\section{CONCLUSION}

The engagement of family members in the care and rehabilitation of ICU patients creates an atmosphere of friendliness and trust between the doctor, the patient and the patient's family. This fosters social adaptation of the patient and promotes positive changes to the patient's emotional and cognitive state.

We are planning to create a digital platform that will contain information for family members and other caregivers. Using the platform, the caregiver will have 24/7 access to the medical personnel and make notes on all manipulations he/she performs, i.e. keep a digital diary. Information on the website will remind the caregiver of the correct massaging technique against bedsores, proper nutrition diet, etc. Besides, the platform will help to shorten the duration of rehabilitation, improve its quality and save money on nonemergency cases.

The study found that relatives of ICU patients are very concerned about the patient's health (100\%), willing to assist medical personnel in delivering care to and rehabilitating the patient $(97.1 \%)$, but usually do not have the necessary skills (65.7\%). The study proposes the criteria for selecting family members for the medical care training course and the program for the course.
3. Federal'nyy zakon ot 21.11.2011 N 323-FZ (red. ot 31.07.2020) "Ob osnovakh okhrany zdorov'ya grazhdan v Rossiyskoy Federatsii» Russian. Spravochnaya sistema "Konsul'tant Plyus». Versiya Prof. http://www.consultant.ru/document/cons_doc_ LAW_121895/ Russian.

4. Zaklyuchenie Komiteta po okhrane zdorov'ya ot 05.06.2018 "Po proektu federal'nogo zakona N 359335-7 "O vnesenii izmeneniya $v$ chast' 1 stat'i 79 Federal'nogo zakona "Ob osnovakh okhrany zdorov'ya grazhdan v Rossiyskoy Federatsii" Russian. Spravochnaya sistema "Konsul'tant Plyus». http:// www.consultant.ru/cons/cgi/online.cgi? $r e q=$ doc\&base $=P R J$ $\& n=175425 \# 023846454769159475 /$ Russian.

5. Informatsionno-metodicheskoe pis'mo «O pravilakh poseshcheniya rodstvennikami patsientov $v$ otdeleniyakh reanimatsii $\mathrm{i}$ intensivnoy terapii (reanimatsii)» i Forma pamyatki dlya posetiteley» Russian. Spravochnaya sistema «Konsul'tant Plyus». Versiya Prof. http:// www.consultant.ru/document/cons_doc_LAW_202679/ Russian.

6. Postanovlenie Glavnogo gosudarstvennogo sanitarnogo vracha RF ot 24 dekabrya 2020 g. № 44 "Ob utverzhdenii sanitarnykh 
pravil SP 2.1.3678 - 20 "Sanitarno-epidemiologicheskie trebovaniya $\mathrm{k}$ ekspluatatsii pomeshcheniy, zdaniy, sooruzheniy, oborudovaniya i transporta, a takzhe usloviyam deyatel'nost khozyaystvuyushchikh sub"ektov, osushchestvlyayushchikh prodazhu tovarov, vypolnenie rabot ili okazanie uslug" Russian. Spravochnaya sistema "Garant». https://www.garant.ru/ products/ipo/prime/doc/400063274/ Russian.

7. Proekt Prikaza Ministerstva zdravookhraneniya Rossiyskoy Federatsii ot 19.08.2020 № 869n «Ob utverzhdenii obshchikh trebovaniy k organizatsii poseshcheniya patsienta rodstvennikami i inymi chlenami sem'i ili zakonnymi predstavitelyami patsienta $\checkmark$ meditsinskoy organizatsii, $v$ tom chisle $v$ ee strukturnykh podrazdeleniyakh, prednaznachennykh dlya provedeniya intensivnoy terapii i reanimatsionnykh meropriyatiy, pri okazanii emu meditsinskoy pomoshchi v statsionarnykh usloviyakh» Russian. Spravochnaya sistema «Konsul'tant Plyus». Russian.

8. Prikaz Minzdrava Rossii ot 20.12.2012 N 1177n (red. ot 17.07.2019) "Ob utverzhdenii poryadka dachi informirovannogo dobrovol'nogo soglasiya na meditsinskoe vmeshatel'stvo i otkaza ot meditsinskogo vmeshatel'stva $v$ otnoshenii opredelennykh vidov meditsinskikh vmeshatel'stv, form informirovannogo dobrovol'nogo soglasiya na meditsinskoe vmeshatel'stvo i form otkaza ot meditsinskogo vmeshatel'stva" (Zaregistrirovano v Minyuste Rossii 28.06.2013 N 28924) Russian. Spravochnaya sistema «Konsul'tant Plyus». Versiya Prof. http://www.consultant. ru/document/cons_doc_LAW_149084/Russian.

9. Guryleva ME. Dobrovol'noe informirovannoe soglasie i ego mesto v meditsinskoy praktike. Glavnaya meditsinskaya sestra, 2011; (2): 45-54. Russian.

10. Mukhacheva EA, Pokhodenko IV, Smirnova OP, Baltikova W. Informirovannoe dobrovol'noe soglasie i ego mesto $v$ meditsinskoy praktike. V sbornike: INTERNATIONAL INNOVATION RESEARCH.
Sbornik statey XVII Mezhdunarodnoy nauchno-prakticheskoy konferentsii. 2019; 183-185 p. Russian.

11. Grigoreva IA, Maksimov IL, Zakirov II, Saetgaraev AK. Etikopravovye i organizatsionnye osobennosti privlecheniya rodstvennikov pri reabilitatsii $\vee$ posleoperatsionnom periode organizatsiy. Bioetika i ekzistentsial'nye riski sovremennogo mira. Sbornik nauchnykh statey. Kazan'. 2020; 71-72 p. Russian.

12. Lamas D. Nurse-Led Communication in the Intensive Care Unit. The NEW ENGLAND JOURNAL of MEDICINE. 2018; (378) 2431-2432. DOI: 10.1056/NEJMe1804576/

13. Foà C, Cavalli L, Maltoni A, Tosello N, Sangilles C, Maron I, Borghini M, Artioli G. Communications and relationships between patient and nurse in Intensive Care Unit: knowledge, knowledge of the work, knowledge of the emotional state. Acta Biomed. 2016; 87(4-S):71-82.

14. Ramos KJ, Downey L, Nielsen EL, Treece PD, Shannon SE, Curtis JR, Engelberg RA.J. Using Nurse Ratings of Physician Communication in the ICU To Identify Potential Targets for Interventions To Improve End-of-Life Care. Palliat Med. 2016; 19(3): 292-9. DOI: 10.1089/jpm.2015.0155/

15. Prikaz Minzdrava RF ot 17 aprelya 2002 g. N 123 "Ob utverzhdenil otraslevogo standarta "Protokol vedeniya bol'nykh. Prolezhni" Russian. Spravochnaya sistema «Garant». https://base.garant. ru/4178430/ Russian

16. Prikaz Minzdrava RF ot 5 avgusta 2003 g. N 330 "O merakh po sovershenstvovaniyu lechebnogo pitaniya $\vee$ lechebnoprofilakticheskikh uchrezhdeniyakh Rossiyskoy Federatsii" (s izmeneniyami i dopolneniyami) Russian. Spravochnaya sistema «Garant». https://base.garant.ru/12132439/ Russian.

17. Stratton RJ, Green CJ, Elia M. Disease-related malnutrition: an evidence based approach to treatment. Wallingford: $\mathrm{CABI}$ Publishing; 2003

\section{Литература}

1. Закон «Об утверждении основ законодательства Союза ССР и союзных республик о здравоохранении» от 19 декабря 1969 года (с изм. и доп., внесенными Указами Президиума ВС СССР от 18.06.1979 - Ведомости ВС СССР, 1979, N 25 ст. 438; от 26.03.1984 - Ведомости ВС СССР, 1984, N 13, ст 188; от 08.06.1984 - Ведомости ВС СССР, 1984, N 24, ст. 422 Законом СССР от 27.11.1985 - Ведомости ВС СССР, 1985, N 48, ст. 919; Указом Президиума ВС СССР от 25.08.1987 - Ведомости ВС СССР, 1987, N 34, ст. 560; Законами СССР от 23.04.1990 - Ведомости СНД и ВС СССР, 1990, N 19, ст. 326; от 22.05.1990 - Ведомости СНД и ВС СССР, 1990, N 23, ст. 422). Библиотека нормативно-правовых актов Союза Советских Социалистических Республик. http://www.libussr. ru/doc_ussr/usr_7212.htm/

2. Федеральный закон «Основы законодательства Российской Федерации об охране здоровья граждан» (утв. ВС РФ 22.07.1993 N 5487-1) (ред. от 07.12.2011). Справочная система «Консультант Плюс». Версия Проф. http://www. consultant.ru/document/cons doc_LAW_2413/

3. Федеральный закон от 21.11.2011 N 323-Ф3 (ред. от 31.07.2020) «Об основах охраны здоровья граждан в Российской Федерации». Справочная система «Консультант Плюс». Версия Проф. http://www.consultant.ru/document/ cons doc_LAW_121895/

4. Заключение Комитета по охране здоровья от 05.06.2018 "По проекту федерального закона N 359335-7 "О внесении изменения в часть 1 статьи 79 Федерального закона "Об основах охраны здоровья граждан в Российской Федерации"/ Справочная система «Консультант Плюс». Версия Проф. http://www.consultant.ru/cons/cgi/online.cgi?req=doc\&base=P RJ\&n=175425\#023846454769159475/

5. Информационно-методическое письмо «О правилах посещения родственниками пациентов в отделениях реанимации и интенсивной терапии (реанимации)» и «Форма памятки для посетителей». Справочная система «Консультант Плюс». Версия Проф. http://www.consultant.ru/document/

cons_doc_LAW_202679/

6. Постановление Главного государственного санитарного врача РФ от 24 декабря 2020 г. № 44 "Об утверждении санитарных правил СП 2.1.3678 - 20 "Санитарно-эпидемиологические требования к эксплуатации помещений, зданий, сооружений, оборудования и транспорта, а также условиям деятельности хозяйствующих субъектов, осуществляющих продажу товаров, выполнение работ или оказание услуг". Справочная система «Гарант». https://www.garant.ru/products/ipo/prime/ doc/400063274/

7. Проект Приказа Министерства здравоохранения Российской Федерации от 19.08.2020 № 869н “Об утверждении общих требований к организации посещения пациента родственниками и иными членами семьи или законными представителями пациента в медицинской организации, в том числе в ее структурных подразделениях, предназначенных для проведения интенсивной терапии и реанимационных мероприятий, при оказании ему медицинской помощи в стационарных условиях». Справочная система «Консультант Плюс». Версия Проф.

8. Приказ Минздрава России от 20.12.2012 N 1177н (ред. от 17.07.2019) "Об утверждении порядка дачи информированного добровольного согласия на медицинское вмешательство и отказа от медицинского вмешательства в отношении определенных видов медицинских вмешательств, форм информированного добровольного согласия на медицинское вмешательство и форм отказа от медицинского вмешательства" (Зарегистрировано в Минюсте России 28.06.2013 N 28924). Справочная система «Консультант Плюс». Версия Проф. http://www.consultant.ru/document/ cons doc LAW 149084/

9. Гурылева М.Э. Добровольное инсормированное согласие и его место в медицинской практике. Главная медицинская сестра, 2011; (2): 45-54.

10. Мухачева Е. А., Походенько И. В., Смирнова О. П., Балтикова В. В. Информированное добровольное согласие и его место 
в медицинской практике В сборнике: INTERNATIONAL INNOVATION RESEARCH. Сборник статей XVII Международной научно-практической конференции. 2019; 183-185 с.

11. Григорьева И. А., Максимов И. Л., Закиров И. И., Саетгараев А. К. Этико-правовые и организационные особенности привлечения родственников при реабилитации в послеоперационном периоде организаций. Биоэтика и экзистенциальные риски современного мира. Сборник научных статей. Казань. 2020; 71-72 с.

12. Lamas D. Nurse-Led Communication in the Intensive Care Unit. The NEW ENGLAND JOURNAL of MEDICINE. 2018; (378): 2431-2432. DOI: 10.1056/NEJMe1804576/

13. Foà C, Cavalli L, Maltoni A, Tosello N, Sangilles C, Maron I, Borghini M, Artioli G. Communications and relationships between patient and nurse in Intensive Care Unit: knowledge, knowledge of the work, knowledge of the emotional state. Acta Biomed.
2016; 87(4-S):71-82.

14. Ramos KJ, Downey L, Nielsen EL, Treece PD, Shannon SE, Curtis JR, Engelberg RA.J. Using Nurse Ratings of Physician Communication in the ICU To Identify Potential Targets for Interventions To Improve End-of-Life Care. Palliat Med. 2016; 19(3): 292-9. DOI: 10.1089/jpm.2015.0155/

15. Приказ Минздрава РФ от 17 апреля 2002 г. N 123 "Об утверждении отраслевого стандарта "Протокол ведения больных. Пролежни". https://base.garant.ru/4178430/

16. Приказ Минздрава РФ От 5 августа 2003 г. N 330 "О мерах по совершенствованию лечебного питания в лечебнопрофилактических учреждениях Российской Федерации" (с изменениями и дополнениями). https://base.garant.ru/12132439/

17. Stratton RJ, Green CJ, Elia M. Disease-related malnutrition: an evidence based approach to treatment. Wallingford: CABI Publishing; 2003. 


\title{
ETHICAL ISSUES IN DISCLOSING DIAGNOSTIC AND PROGNOSTIC INFORMATION TO CANCER PATIENTS
}

\author{
Vvedenskaya EV1,2凶, Lepkova NV¹, Egorova AV1 \\ ${ }_{1}$ Pirogov Russian National Research Medical University, Moscow, Russia \\ 2 INION RAS Moscow, Russia
}

\begin{abstract}
The article talks about the ethical dilemmas of diagnostic and prognostic disclosure in oncology. Below, we discuss the principles of diagnostic and prognostic disclosure to curable and terminally ill patients proposed by Soviet medical deontology. Despite its evolution, the principle of benevolent deception applied to incurable patients in the USSR still persists into the present. The article discusses the cons and pros of withholding the diagnosis from terminally ill patients and the Russian legislation on the patient's rights. The article places a special focus on the strategy of disclosing an unfavorable diagnosis to a cancer patient adopted in Russian oncology.
\end{abstract}

Keywords: informing, informed consent, oncology, deontology, "benevolent deception", diagnosis

Author contribution: Vvedenskaya EV — studying literature, writing an article; Lepkova NV, Egorova AV — contribution to the concept and structure of the article, editing

$\triangle$ Correspondence should be addressed: Helena V. Vvedenskaya

Ostrovityanova st. 1, Moscow; vvedenskaya.elena@gmail.com

Received: 12.02.2021 Accepted: 26.03.2021 Published online: 31.03.2021

DOI: $10.24075 /$ medet.2021.005

\section{ЭТИЧЕСКИЕ ПРОБЛЕМЫ ИНФОРМИРОВАНИЯ ОНКОЛОГИЧЕСКИХ ПАЦИЕНТОВ В РОССИИ}

\author{
Е. В. Введенская $1,2 凶$, Н. В. Лепкова ${ }^{1}$, А. В. Егорова ${ }^{1}$ \\ ${ }^{1}$ Российский национальный исследовательский медицинский университет имени Н. И. Пирогова, Москва, Россия \\ 2 ИНИОН РАН Москва, Россия
}

Статья посвящена этическим проблемам информирования пациентов в онкологии. Анализируются принципы инсормирования онкологических больных, в том числе инкурабельных, разработанные в советской медицинской деонтологии. Отмечается, что принцип «доброжелательного обмана», принятый в отношении инкурабельных больных в СССР, претерпевает эволюцию в отечественной онкологии, однако не преодолен в полной мере к настоящему времени. Рассматриваются аргументы «за» и «против» сокрытия врачами онкологического диагноза для неизлечимых больных, а также требования российского законодательства в отношении соблюдения прав пациента. Особое внимание уделено информированию пациента и тактике сообщения неблагоприятного диагноза в современной российской онкологии.

Ключевые слова: информирование, информированное согласие, онкология, деонтология, “доброжелательный обман», диагноз

Вклад авторов: Введенская Е. В. - изучение литературы, написание статьи; Лепкова Н. В., Егорова А. В. - вклад в концепцию и структуру статьи, редактирование.

$\bigotimes$ Для корреспонденции: Елена Валерьевна Введенская,

ул. Островитянова, д. 1, г. Москва, 117997; vvedenskaya.elena@gmail.com

Статья получена: 12.02.2021 Статья принята к печати: 26.03.2021 Опубликована онлайн: 31.03.2021

DOI: $10.24075 /$ medet.2021.005

For an oncologist, the ability to establish rapport and achieve cohesion with a cancer patient is just as essential as the high level of competence. According to eminent Soviet oncologists, "any disruption of this cohesion can have a tragic effect on the patient's life" [1]. One of the most complex ethical dilemmas faced by oncologists is whether to withhold or disclose the diagnosis, prognosis and difficulties associated with treatment, including surgical interventions, to a cancer patient.

\section{Deontological ethics in Soviet medicine and full disclosure in oncology}

Prognostic and diagnostic disclosure in oncology was extensively debated in the Soviet medical deontological literature. One of the key works on this problem published during the Soviet period was a scholarly monograph Questions of surgical deontology by Nikolai N. Petrov, the member of the Soviet Academy of Medical Sciences, which enunciated the basic deontological principles of Soviet surgery. "A patient is not a faceless case but an individual with complex feelings", Petrov wrote; therefore, physicians "should look for a treatment suitable for the patient instead of looking for a patient suitable for a therapeutic intervention" [2]. Petrov argued the need for a personalized approach to treatment. The essence of this approach was articulated in 4 Preoperative Conclusions: 1 motivated diagnosis; 2 - indications for surgery; 3 - surgery plan; 4 - anesthesia. Obviously, the conclusions had to be drawn based on the meticulous study of the patient's personality and in his/her best interest. In other words, a few decades before the science of bioethics emerged, Petrov had defined its fundamental principle: respect for patient autonomy. The Soviet surgeon recommended that physicians should discuss the available treatment options with the patient and let the patient decide whether the proposed surgical intervention was worth-while. Petrov held the opinion that "by adopting a tactful and friendly attitude to the patient, the surgeon can engage them into decision making about surgery" [2]. However, the "respect for patient autonomy" rule did not apply to incurable patients, who were taken care of in a paternalistic fashion.

According to the ethics of the Soviet medical practice, physicians were expected to have a lot of consideration for the mental health of cancer patients and avoid using words like cancer, sarcoma or metastasis in their presence so as to reduce the probability of reactive psychiatric disorders, distress and hysterical fits. It was recommended that the diagnosis should not be disclosed to the incurable patient and the patient should be given the impression that he/she was receiving some therapy, i.e. the patient was told they had "gastric ulcer" or a 
"tumor" and was prescribed unrelated long-term therapy [2]. When dwelling on the communication between the doctor and the patient, Petrov said that although it is impossible to predict how the conversation with the patient might go, an experienced physician with good knowledge of deontology can find the right words, imagining that their patient is "someone special they seek to give relief to by all means, but not a faceless uninteresting case" [2].

In Petrov's monograph written a few years before the Nuremberg Code (1947), there is a chapter proposing the concept of informed consent. The bioethicist E.P. MikhalovskaKarlova observed that "requirements formulated by Petrov almost mirrored the content of informed consent as we know it today" [3]. Petrov believed that the doctor should talk to the patient about the diagnosis and surgery in simple unintimidating terms, providing some prognostic details and information about mandatory prophylaxis. If a surgical intervention is necessary, the surgeon must insist on it and yet mention a few possible risks, like the risk of infection or injury; however, the surgeon must emphasize that the risks far outweigh the benefits of surgery. Importantly, Petrov recognized the need for full disclosure only in cases when there was no other way to obtain informed consent from the patient.

According to Petrov, if a patient is inoperable or surgery is associated with significant risks, the surgeon should explain to the patient in plain language that surgery may be fatal or lead to grave complications. Besides, the patient should be informed of preoperative preparations and anesthesia in order to avoid "counterproductive debate or rude altercations in the operating room that discredit surgery as such" [2].

Rules of communication between the doctor and the terminally ill patient formulated by Petrov are based on the principle of benevolent deception, which prescribes to conceal a true terminal diagnosis and tell the patient they have something much less terrifying than cancer. "Not only so-called uninitiated persons but also distinguished surgeons, when they take seriously ill and become patients themselves, believe a skillful well-intentioned lie, find comfort in it and die peacefully with it", Petrov wrote [2]. Alternatively, the doctor may tell the patient the diagnosis is inconclusive and thus let the patient find comfort in doubt. Petrov believed that physicians should maintain the illusion of recovery in an incurable patient for the good of the patient; therefore, the doctor does not have the moral right to tell the patient that their cancer is inoperable and that there is no cure: "It is not advisable to tell a terminally ill patient that he/she is inoperable; instead, the physician should plant a thought in the patient that surgery is not necessary at this stage. Under no circumstances should the physician tell the patient that the medical science has not yet come up with a treatment for their disease and thus deny the patient any treatment. This kills all hope and aggravates suffering" [2].

Deontological principles formulated by Petrov were expanded upon by another member of the Soviet Academy of Medical Sciences, Nikolai N. Blokhin, in his work "Deontology in oncology" (1977). Blokhin addressed a wide range of ethical issues, including the significance of direct communication between the doctor and the patient, the need for full disclosure to patients that can potentially be cured and their close relatives, and the importance of eradicating fringe medicine to which the patient may turn to and thus lose precious time.

Following the ancient principle "first, do no harm", which is ascribed to Hippocrates and prompts the doctor to shield the patient's psyche from a blow, Blokhin echoed Petrov's words by saying: "A doctor must not tell a terminally ill patient the whole truth, although there may be other options in other cases" because "the doctor cannot predict what may happen after the patient hears the truth" [4].

Benevolent deception of incurable patients: evolution of opinions in Russian oncology

Relying on the idea of a kind and caring attitude toward a patient, Petrov and Blokhin advocated the principle of benevolent deception in diagnostic and prognostic disclosure to patients with terminal cancer. In the Soviet time, withholding a dreadful diagnosis was part of adherence to the "patient confidentiality" rule. During the first State-wide USSR Conference on Medical Deontology (1969), Prof. F.V. Gulyaev spoke about the commitment of Soviet physicians to this principle: "We abide by the rule of concealing a cancer diagnosis from the patient, although it is becoming increasingly difficult due to the spread of non-academic medical journals" [5].

The principle of withholding diagnostic and prognostic information from an incurable patient is predicated on the following assumptions. Full diagnostic and prognostic disclosure to a terminally ill patient contradicts the injunction "first, do no harm". It is not rare that a patient, unable to cope with the truth, commits suicide after finding out about their diagnosis. There is a belief that a false benign diagnosis mitigates the course of the disease. Besides, there are diagnostic and prognostic errors. Insisting on the truth, the patient usually wants to hear something optimistic. Telling a terminally ill patient the whole truth suggests professional inadequacy. Russian laws and the Declaration of Lisbon on the Rights of the Patient declare the patient's right not to know.

At the same time, truth is a manifestation of respect for a human being, human dignity and autonomy, i.e. the right for self-determination. Truth is the starting point for making choices about treatment, refusing treatment and dealing with other challenges in life. It is currently held that lying to the patient about the positive outcome is immoral. According to the psychologist A.V. Gnezdilov, such deception does harm to the patient because it is inconsistent with the actual dynamics of the disease. There are patients who realize or intuitively feel that they are being lied to and suffer from the lie even more as the disease progresses. This was brilliantly described by Tolstoy in his novella The death of Ivan Ilyich: "What tormented Ivan Ilyich most was the deception, the lie, which for some reason they all accepted, that he was not dying but was simply ill, and he only need keep quiet and undergo a treatment and then something very good would result. He however knew that do what they would nothing would come of it, only still more agonizing suffering and death. This deception tortured him their not wishing to admit what they all knew and what he knew, but wanting to lie to him concerning his terrible condition, and wishing and forcing him to participate in that lie. Those lies lies enacted over him on the eve of his death and destined to degrade this awful, solemn act to the level of their visitings, their curtains, their sturgeon for dinner-were a terrible agony for Ivan llyich... This falsity around him and within him did more than anything else to poison his last days" [6].

The incurability of some cancer patients brings up the question: "Could it be that by defending their privilege to lie to terminally ill patients some oncologists reveal their own fear of death and therefore cannot maintain their professional attitude with dying patients?". Prof. J. Klaesi once made a fair observation that the ultimate mission of the doctor begins when chances of curing the patient have run out. Expanding upon Klaesi's thought, V.Frankl, a Nazi camp survivor who had witnessed the suffering of those sentenced to death, wrote that the doctor should care for the patient's soul and help them endure their ordeals. "It is not about recovering the ability to 
work or enjoy life, for these abilities are irreversibly lost, but about developing the ability to endure suffering" [7].

In the West, the ethical dilemma of diagnostic disclosure to a cancer patient has been almost completely solved. Oncologists are obliged by the law to tell the truth to their patients, otherwise the patient may sue the healthcare provider for withholding information. The first legal document protecting the rights of the patient was the Patient's Bill of Rights adopted by the American Hospital Association in 1973. One of the key provisions of the Bill was the patient's right for "relevant, current, and understandable information about his or her diagnosis, treatment, and prognosis" [8]. However, Declaration of Lisbon adopted in 1981 ruled that "exceptionally, information may be withheld from the patient when there is good reason to believe that this information would create a serious hazard to his/her life or health" [9]. In 1994, the European Consultation on the Rights of Patients adopted the Declaration on the Promotion of Patients' Rights in Europe. This document declared the patient's right for exhaustive information about their health, including information about possible risks and advantages of alternative treatment options [10].

In the 1990s, full diagnostic and prognostic disclosure was advocated by Nikolai N. Trapeznikov, director of Blokhin National Medical Research Center of Oncology. Owing to scientific and technological advances in cancer treatment, the word "cancer" was no longer perceived as a synonym of painful death. The Constitution of Russia adopted in 1992 now guaranteed and protected human rights, which, in the context of public health, meant protection of patients' rights.

Article 41 of the current Constitution proclaims the right for health protection and medical care, including protection against adverse yet inevitable consequences of treatment. This obliges the doctor to inform the patient about all possible side effects of treatment, its effectiveness, the right to refuse therapy, and disease progression in the absence of treatment [11].

In Russia, the doctor-patient relationship is regulated by the Federal law № 323 On the fundamental principles of public health protection № 323 passed in 2011. Article 19 of this Law guarantees that the patient has the right to obtain information about his/her rights, responsibilities, and health condition and to choose a representative to receive information about the patient's health on his/her behalf [12].

Article 20 prohibits performing any healthcare intervention on the patient in the absence of informed consent obtained from the patient or their legal representative. Informed consent is based on the patient's understanding of information provided to the patient or their legal representative by the healthcare provider about treatment goals, methods, risks, consequences, options and outcomes [12].

However, contrary to legal requirements, diagnostic and prognostic disclosure is not always practiced as it should be. Disclosure is still a moral dilemma for the doctor who is the one to decide whether to tell or not to tell the whole truth to a terminally ill patient. Oncologists have to consider the physical, mental, and emotional states of their patients and determine if the later are ready to hear the truth. According to Article 22 of the Federal Law № 323, information about the patient's health cannot be delivered to the patient against their will [12]. The existing solution to the ethical dilemma of full disclosure is ambiguous: the patient has the right to know and the right to refuse information regarding their health. Not every patient wants to know about their diagnosis, and so keeping the patient in the best possible health, both physical and mental, should be the physician's top priority.

\section{Diagnostic and prognostic disclosure and communication strategies in contemporary Russian oncology}

The conversation between the doctor and the patient is a crucial moment. The more experienced the doctor, the less the patient struggles with understanding and accepting the diagnosis and the more confidence he/she has in the positive outcome. According to the Federal Law No.323, every patient has the right for full and understandable information about their diagnosis, results of diagnostic tests, treatment options, risks and prognosis. This information is provided by the attending physician or another healthcare worker involved in diagnosing and treating the patient. If the patient is underage or legally incapacitated, the physician discloses diagnostic and prognostic information to their legal representative.

Because Soviet deontology had been following its own idiosyncratic path and due to the specific features of the Russian mentality and the way of life, Russian oncologists take a very subtle, personalized approach to breaking bad news to the patient. According to Irina M. Starovoytova of the Russian Medical Academy of Continuous Professional Education, a Russian oncologist "has to undertake the grueling task of conveying the diagnosis in a way that will give the patient hope, mobilize them for radical treatment and yet be truthful but not blunt" [13].

Patients respond to bad news differently, depending on their higher nervous activity type [14]. In their practice, Russian oncologists use the classification of personality types first proposed by Hippocrates (the $5^{\text {th }}$ century $\mathrm{BC}$ ) and later expanded upon by Galen (the $2^{\text {nd }}$ century $\mathrm{BC}$ ). In the 20th century, the outstanding Soviet scientist Ivan Pavlov proved that the higher nervous activity type is the biological basis of temperament [15]. According to the temperamentbased classification of personality types, a sanguine person is characterized by frequent mood swings, short duration of impressions, and fast response to the environment; this personality type easily reconciles with failures and troubles. A phlegmatic individual is usually composed, persistent, steadfast, calm and does not show their emotions and feelings much. Sanguine and phlegmatic individuals are not difficult patients. They take their diagnosis calmly and forge ahead to recovery if their doctor maintains good contact with them and informs them of all diagnostic and therapeutic steps that need to be taken.

Choleric and melancholic individuals are more difficult patients. A choleric person is quick, impulsive, passionate, volatile, easily tired, and has frequent mood swings and emotional outburst. When conversing with a choleric patient, the doctor should be very attentive, calm and level-headed. Such patients need to be repeatedly reminded of the importance of diagnostic and therapeutic manipulations.

A melancholic individual is very vulnerable, anxious, and weakly responds to the environment. This personality type cannot hold back their asthenic feelings by willpower alone and is very sensitive. The physician should not be straightforward about the diagnosis with a melancholic patient; it is advisable to arrange for a candid and intimate conversation with the patient and then calmly and confidently tell the patient that in order to recover he/she needs therapy. It is important to show tact and patience, to use synonyms instead of direct medical terms when talking about the disease. The primary goal of the conversation is to help the patient accept the diagnosis and motivate them to undergo treatment despite the hardships associated with it. The more positive attitude the patient has, the more effectively their therapy will work. But if the patient 
refuses to know the diagnosis, the doctor has no right to force this information upon them. Instead, the diagnosis should be tactfully communicated to the patient's representatives.

Understanding what the patient wants and being ready to help them digest the bad news is conducive to a successful conversation. The doctor should listen to and hear the patient. Gnezdilov writes: "When engaging in a dialogue with the patient, the doctor should be the listener and give the patient the opportunity to take an active lead. Sometimes the patient simply needs to vent their emotion but one should not forget that the patient always watches closely the doctor's response to it" [16].

It is important to give information to the patient in small chunks. This will help the patient get ready for hearing the truth in its entirety. A sensitive physician will know when the time is right for full disclosure. According to Gnezdilov, every successive conversation will be more open and detailed. He writes: "For example, a cancer patient is initially in blissful ignorance; so, the physician should start by explaining them what a neoplasm is; in the next conversation the doctor can bring up the term tumor, then a malignant tumor, then cancer and metastasis, and so on" [16].

Another thing to consider when communicating with a patient is the cycle of acceptance. It consists of 5 stages identified by the Swiss-American psychiatrist Elisabeth KüblerRoss (1969). There is no particular deadline for any of these stages [17]. They can be briefly described as follows:

Stage 1: shock or denial. At first, the patient cannot grasp the reality of what has happened. At this stage, the patient should not be left on his own. The physician should explain that the diagnosis is not a death sentence. Reassurance and emotional support should be provided. Often, the shock is followed by panic and overwhelming fear. To cope with the fear, the patient often goes in denial, which is not a positive sign because disbelief delays treatment.

Stage 2: anger. On the one hand, anger is a normal response to a life crisis; on the other hand, it may be destructive and dangerous for the patient.

Stage 3: bargaining. At this stage, the patient tries to come to terms with the situation by striking a deal with god or himself/ herself.

Stage 4: depression. Almost all patients experience depression to a greater or lesser degree because the disease interferes with their plans for the future. The hardest part for both the doctor and the patient is when the patient gets stuck in depression. The doctor should find the right words to convince the patient that their plans may still be workable and advances in cancer treatment may help them fulfill their hopes.

Stage 5: acceptance and reassessment. Accepting a grave diagnosis is not the same thing as putting up with it. Acceptance implies understanding. A patient who has accepted their diagnosis and reassessed their priorities will agree to treatment, take it with dignity, and possibly become a role model for others.

A patient can quickly go through any of these stages, or skip it, or even get stuck in it; the most important thing is to forge ahead, reach acceptance and initiate therapy without delay.

Oncologists communicate with their patients as the later go through the cycle of acceptance and various diagnostic and therapeutic procedures. The doctor should pay attention to all nuances of the patient's physical and emotional state and their response to the information about their diagnosis, treatment and prognosis. The knowledge of psycho-oncology techniques might be invaluable in managing and rehabilitating a cancer patient [18]

\section{References}

1. Chissov VI, Gricman JuJa, Shubin BM. Deontologija v prakticheskoj onkologii/ Deontologija $\vee$ medicine: $v 2$ t. T.2. Chastnaja deontologija. Petrovskii BV, editor. M.: Medicina; 1988; 103 s. Russian.

2. Petrov NN. Voprosy hirurgicheskoj deontologii. L.: GIDUV; 1945 60 s. Russian.

3. Mihalovska-Karlova EP. Formirovanie biojeticheskih predstavleni $\checkmark$ hirurgicheskoj deontologii NN Petrova. Bjulleten' Nacional'nogo nauchno-issledovatel'skogo instituta obshhestvennogo zdorov'ja imeni NA Semashko. 2015; (1):124-126. Russian.

4. Blohin NN. Deontologija v onkologii. - M.: Medicina; 1977; $120 \mathrm{~s}$.

5. Jarovinskij MJa. Medicinskaja jetika (biojetika). Stochik AM., editor. M.: OAO «Izdatel'stvo Medicina»; 2006; 196 s. Russian.

6. Tolstoj LN. Smert' Ivana II'icha. Sobranie sochinenij $\vee 12$ t. M.: «Pravda»; 1987; (11): 80 s. Russian.

7. Frankl V. Teorija i terapija nevrozov. Vvedenie $v$ logoterapiju i jekzistencial'nyj analiz. Zaporozh'e: Big-Press; 2012; 32 s. Russian.

8. AHA Patient's Bill of Rights APRA. http: americanpatient.org/

9. Lissabonskaja deklaracija prav pacienta: prin. na 34-j Vsemirnoj medicinskoj assamblee, Lissabon, Portugalija, 1981 g.; dopoln. na 47-j General'noj Assamblee, Bali, Indonezija, 1995. http:// www.e-stomatology.ru/star/info/2010/lissabon_declaration.htm/

10. Deklaracija o politike $v$ oblasti obespechenija prav pacientov $\vee$

Evrope: utv. Evropejskim bjuro VOZ, Amsterdam, 1994. http:// europadonna.by/index. php?option=com_content\&view=article\& $\mathrm{id}=89: 2010-01-23 /$

11. Konstitucija Rossijskoj Federacii. M.: Jeksmo; 2009; 64 s. Russian.

12. Federal'nyj zakon ot 21 nojabrja 2011 g. N 323-FZ «Ob osnovah ohrany zdorov'ja grazhdan v Rossijskoj Federacii». http://base. garant.ru/12191967/ Russian.

13. Starovojtova IM. Jetika i psihologija $v$ onkologii. Materialy $X$ Rossijskogo onkologicheskogo kongressa 21-23 nojabrja 2006 goda, Moskva. https://rosoncoweb.ru/library/congress/ru/10/22. $\mathrm{php} /$ Russian.

14. Gancev SHH. Onkologiya. Uchebnik dlya medicinskih vuzov. M.: Medicinskoe informacionnoe agentstvo; 2006; 159 s.

15. Pavlov IP. Fiziologicheskoe uchenie o tipah nervnoj sistemy, temperamentah tozh, Poln. Sobr. Soch., kn. 2. M-L, 1951; (3): 77-88. Russian.

16. Gnezdilov AV. Psihologiya i psihoterapiya poter'. Posobie po palliativnoj medicine dlya vrachej, psihologov i vsekh interesuyushchihsya problemoj. SPb.: Rech'; 2002; 162 s. Russian.

17. Kyubler-Ross E. O smerti i umiranii. M.: Sofiya; 2001; 320 s.

18. Belyaev AM et al. Onkopsihologiya dlya vrachej-onkologov i medicinskih psihologov. Rukovodstvo. SPb: Lyubavich; 2017; 352 s. Russian.

\section{Литература}

1. Чиссов В. И., Грицман Ю. Я., Шубин Б. М. Деонтология в практической онкологии. Деонтология в медицине: в 2 т.

Т2. Частная деонтология. Петровский Б. В., редактор. М. Медицина; 1988; 103 с. 
2. Петров Н. Н. Вопросы хирургической деонтологии. Л.: ГИДУВ; 1945; 60 c.

3. Михаловска-Карлова Е. П. Формирование биоэтических представлений в хирургической деонтологии Н. Н. Петрова. Бюллетень Национального научно-исследовательского института общественного здоровья имени Н. А. Семашко, 2015; (1):124-126.

4. Блохин Н. Н. Деонтология в онкологии. М.: Медицина; 1977; $120 \mathrm{c}$.

5. Яровинский М. Я. Медицинская этика (биоэтика). Сточик А. М. редактор. М.: ОАО «Издательство Медицина», 2006; 196 с.

6. Толстой Л. Н. Смерть Ивана Ильича. Собрание сочинений в 12 т. М.: «Правда»; 1987; (11): 80

7. Франкл В. Теория и терапия неврозов. Введение в логотерапию и экзистенциальный анализ. Запорожье: БигПресс; 2012; 32 c.

8. AHA Patient's Bill of Rights APRA. http: americanpatient.org/

9. Лиссабонская декларация прав пациента: прин. на 34-й Всемирной медицинской ассамблее, Лиссабон, Португалия, 1981 г.; дополн. на 47-й Генеральной Ассамблее, Бали, Индонезия, 1995 г. http://www.e-stomatology.ru/star/info/2010/ lissabon_declaration.htm /

10. Декларация о политике в области обеспечения прав пациентов в Европе: утв. Европейским бюро ВОЗ, Амстердам, 1994. http://europadonna.by/index. php?option=com_content\& view=article\&id=89:2010-01- 23/

11. Конституция Российской Федерации. М.: Эксмо; 2009; 64 с.

12. Федеральный закон от 21 ноября 2011 г. N 323-Ф3 «Об основах охраны здоровья граждан в Российской Федерации». http://base.garant.ru/12191967/

13. Старовойтова И. М. Этика и психология в онкологии. Материалы X Российского онкологического конгресса 2123 ноября 2006 года, Москва. https://rosoncoweb.ru/library/ congress/ru/10/22.php/

14. Ганцев Ш. Х. Онкология. Учебник для медицинских вузов. М.: Медицинское информационное агентство: 2006; 159 с.

15. Павлов И. П. Физиологическое учение о типах нервной системы, темпераментах тож. Полн. Собр. Соч., кн. 2. М-Л; 1951; (3): 77-88.

16. Гнездилов А. В. Психология и психотерапия потерь. Пособие по паллиатив ᄀной медицине для врачей, психологов и всех интересующихся проблемой. СПб.: Речь; 2002; 162 с.

17. Кюблер-Росс Э. О смерти и умирании. М.: София; 2001; 320 с.

18. Беляев А. М. и др. Онкопсихология для врачей-онкологов и медицинских психологов. Руководство. СПб: Любавич; 2017; 352 c. 


\section{INFORMED CONSENT IN RUSSIA: MISUSE AND ABUSE}

Mylnikova IS $\square$

Pirogov Russian National Research Medical University, Moscow, Russia

Even T. Beauchamp and J. Childress, the founders of ethical principlism, noted that in practice the principles of bioethics, which they might have formulated, may conflict, and adherence to one principle may violate the other. To date, the conflict between the principle of autonomy and the doctrine of informed consent, and the principle of vulnerability formulated ten years later (one of the principles introduced by P. Kemp) and the necessity to take care of the patient is one of the major irreconcilable conflicts. This conflict is especially severe in Russia, where the informed consent was immediately enshrined as a statutory provision without prior discussion with the medical and non-medical communities, which gave rise to numerous opportunities for misuse and abuse, and stepped up the bureaucratic pressure both on patients, who became more vulnerable, and the physicians, who started using the informed consent to their advantage, sometimes being openly market-oriented. The growth of mutual mistrust, sometimes reaching the level of aggression, forces one to find a remedy for this situation. In the author's view, this requires revision of the patient's autonomy concept and the concept of informed consent considering the acceptance of the patient's intense vulnerability and the patient's need for the healthcare specialists' (physicians and nurses) personal involvement and care. It may be helpful to consult the writings of the ethics of care, feminist ethics and other ethical trends representation, as well as the results of field research aimed to combine principles of freedom and patient care in a given situation.

Keywords: informed consent, principle of autonomy, ethics of choice, principle of vulnerability, ethics of care

Correspondence should be addressed: Irina S. Mylnikova

Ostrovityanova st. 1, Moscow, 117997; expert.med@mail.ru

Received: 12.03.2021 Accepted: 26.03.2021 Published online: 31.03.2021

DOI: $10.24075 /$ medet.2021.007

\section{ИНФОРМИРОВАННОЕ СОГЛАСИЕ В РОССИИ: ИСКАЖЕНИЯ И ЗЛОУПОТРЕБЛЕНИЯ}

И. С. Мыльникова

Российский национальный исследовательский медицинский университет имени Н. И. Пирогова, Москва

Еще основатели этического принципализма Т. Beauchamp и J. Childress отмечали, что сформулированные ими принципы биоэтики на практике могут вступать в противоречие, когда следование одному из них нарушает другой. Одно из наиболее непримиримых противоречий на сегодня - между принципом автономии и правилом информированного согласия и сформулированным десятилетием позже принципом уязвимости (один из принципов П. Кемпа) и необходимостью заботы о пациенте. Особенно остро это противоречие проявляется в России, где, без предварительного обсуждения медицинской и немедицинской общественностью, информированное согласие сразу было закреплено в качестве законодательной нормы, что породило массу злоупотреблений и искажений, усилило бюрократическое давление как на пациентов, сделав их еще более уязвимыми, так и на врачей, которые стали использовать информированное согласие в своих, иногда откровенно рыночных, интересах. Рост взаимного недоверия, которое иногда доходит до проявлений агрессивности, заставляет искать выход из сложившейся ситуации, который, с точки зрения автора, требует пересмотра концепции автономии пациента и информированного согласия с учетом признания глубокой уязвимости пациента и его потребности в неравнодушии и заботе со стороны медицинских работников - врачей и медицинских сестер. Здесь может помочь знакомство с трудами представителей этики заботы, феминистической этики и других этических направлений, а также с результатами «полевых» исследований, в ходе которых делается попытка в каждой конкретной ситуации совместить принцип свободы и заботу о пациенте.

Ключевые слова: информированное согласие, принцип автономии, этика выбора, принцип уязвимости, этика заботь

$\bowtie$ Для корреспонденции: Ирина Сергеевна Мыльникова

ул. Островитянова, д. 1, г. Москва, 117997; expert.med@mail.ru

Статья получена: 12.03.2021 Статья принята к печати: 26.03.2021 Опубликована онлайн: 31.03.2021

DOI: $10.24075 /$ medet.2021.007

\section{Preface}

As a lecturer in bioethics, the author has an opportunity to ask the trainees, i.e., students, postgraduate students, physicians and nurses, about their interpretation of the informed consent rationale: whose rights are protected by this process? The vast majority give an emphatic response without hesitation: the interests of physician (nurse). And then they explain: the patients should be responsible for their decisions, the physician is not a nanny for his patient, etc. It seems that many modern physicians sort of forgot, or, may be, did not even know, that the informed consent was set up to protect the patient against high-handedness of the medical specialists and was considered the greatest achievement for the protection of human rights. They don't realize that the use of informed consent for the benefit of physicians may give rise for numerous opportunities for misuse and abuse, which quite often violate the rights of the patients for protection of whom the informed consent has once been invented. What are the reasons for such misperception, and what are the prospects for the informed consent within the framework of healthcare system in Russia?

\section{Historical background of the informed consent, Russia (1924)}

The world's first requirement for the patient's consent to surgery was laid down by the Decree of the All-Russian Central Executive Committee and the RSFSR's Council of People's Commissars "On Professional Work and the Rights of Medical Specialists" issued on December 1, 1924. Article 20 of the Decree stated: "surgical procedures are performed with the patient's consent, and in individuals under the age of 16 and mentally ill patients these are performed with the consent obtained from their parents or guardians. Immediate surgery, essential to save the life or the important organ, may be performed by the doctor after a consultation with the other doctor without the consent of 
a parent or guardian, in case they cannot be asked without risk of being late, and without patient's consent in case the patient is unconscious. Given the consultation involves a risk of being late, the doctor can make the decision for surgery himself. He must inform the Health Board about each of these cases no later than in twenty four hours".

As shown in the text of the Decree article, the consent was applied only to surgery, no provision had been made for the consent to be documented in writing, and the question of refusal of surgery was out of consideration. However, the document was truly revolutionary and, with minor modifications, remained relevant for many decades.

In 1970-1993, the main legal instrument governing the health system performance in the USSR was the "Fundamentals of Legislation of the USSR and the Union Republics on the Health Service" dated December 19, 1969, 14589 -VII (entered into force on June 1, 1970). Article 35 of the Fundamentals on the consent to surgery almost entirely reproduced the norms set out in the Decree issued in 1924: "Surgical procedures are performed and advanced diagnosis methods are applied with the patient's consent, and in patients under the age of 16 and mentally ill patients these are performed or applied with the consent obtained from their parents, guardians or caregivers. Immediate surgical procedures are performed and advanced diagnosis methods are applied by doctors without the consent obtained from the patients, their parents, guardians or caregivers only in very exceptional circumstances, when the delays in diagnosis or surgical treatment threaten the life of the patient, and obtaining the consent of the above-mentioned category of persons is impossible".

As can be seen, in the new version of the article there were still shortcomings present in the version issued in 1924, and this version of the document was valid until 1993. It had not been amended in order to reflect new perceptions of the consent being informed and voluntary. Such perceptions had also gained recognition in the American medicine and with a lag had ventured into European medicine.

Emergence of the term "informed consent" in Nuremberg. First steps of biomedical ethics in the USA. Principlism, patient autonomy and the informed consent

As is well known, the concept of the informed consent was formulated in the Nuremberg Code based on the results of the Nazi doctors trial. At first, the informed consent was applied only to human biomedical experimentation, however, ten years later it was used more and more widely by the American private healthcare, becoming the essential element of the doctor-patient relationship. Later the informed consent formed the basis of the American bioethical principlism declaring respect for the rights and freedoms of the patient. According to Tom Beauchamp and James Childress, the Founding Fathers of the novel biomedical ethics, the doctrine of the informed consent, along with the doctrines of confidentiality and truthfulness, ensured compliance with four basic principles of biomedical ethics, one of which was the patient autonomy principle (1976). When introducing new approach to ethical regulation in biomedicine, T. Beauchamp and J. Childress [1] pointed out the difficulties that might arise in case of the conflict between two or more basic principles of bioethics in certain circumstances upon attempting to make a right decision, for example between "respect for autonomy" and "non-maleficence", or "beneficence" and "justice". The researchers emphasized that the principles were not arranged in a hierarchy, and that the decision-making person had an opportunity to choose the most adequate norm to follow.
Over the years, it has become clear that in the American medicine the priority had mainly been given to the principle of supporting the patient's autonomy, as well as to informed consent making it possible to implement this principle. Autonomy refers to acknowledgement of the patient's right to hold views, to make choices and to take actions based on personal values and beliefs [1]. When implementing this principle, the physician must not only show respect for the patient's personality, but also support the patient and enhance his ability to make autonomous decisions, limiting the patient only in case his decision poses a threat to other people. No wonder such ethics was referred to as ethics of choice. Later it was set in opposition to the ethics of care, as discussed below. Private healthcare in the USA, into which the ideas of consumerism had spread, engulfing all American community experiencing the post-war economic boom, easily absorbed this particular variant of bioethical principlism with a focus on respect for the freedom of choice of the patient as the healthcare consumer.

\section{First steps of bioethics in Europe. Criticism of American principlism. Principle of vulnerability and new approach to informed consent}

European bioethics was 10-15 years behind the American bioethics. It was a short period. However, it was long enough to understand that disparities between the principles of "respect for autonomy" and "beneficence" might be irreconcilable. European humanism with the concept of social solidarity was unable to fully accept American ethics of choice. European specialists in bioethics often give a negative answer to a question "how "moral" are the principles of biomedical ethics" introduced by T. Beauchamp and J. Childress (Marcus Christen et al, 2014). [2]. While acknowledging the imperfections of the four principles of American bioethics, without departing from principalism, European bioethics introduced the different set of basic principles: principles of respect for autonomy, dignity, integrity and vulnerability. When speaking of autonomy, European bioethics gave this concept a new interpretation with a focus on personal freedom in the broadest sense of the term, without limiting it to the right to choose. At the same time, great importance was attached to the principle of patient's vulnerability, underpinning the environment of patient powerlessness and dependency, and justifying the moral responsibility of fellow man to take care of those who are unable to care about themselves. Thus, in the dispute between the right to choose and the right to care European bioethics made care a priority. That is how the conflict between two approaches to ethical regulation in biomedicine emerged, the conflict between ethics of choice and ethics of care.

The conflict of those expanded across the interpretation of the informed consent. European ethics of care does not deny the doctrine of the informed consent, however, the interpretation is different. The doctrine is considered not the need to ensure conditions allowing the patient to make a free and responsible choice, but helping the patient to find the acceptable way to recovery (reducing suffering, improving the quality of life), which is consistent with the patient's values and abilities. This approach requires not just awareness-raising, but quality empathic interpersonal interaction between the patient and the physician. In this approach the proponents of the ethics of choice see the signs of the condemned paternalism, which deprives patient of his liberty. However, they completely miss the point, that formal informed consent process is often accompanied by total indifference to patient. There is a problem 
that is "not that others are trying to command you, but that no one cares about you". (Annemarie Mol, 2008) [3]. According to the ethics of care logic, the informed consent may be an act of caring about somebody, as natural as reaching out hands to a person, who has fallen in the street, in order to support. It is worth emphasizing that debates over two approaches to solving the problems of morality in medicine continue to this day.

\section{Informed consent in Russia. Legal acts issued in 1993 and 2011}

But let us return to Russia, where in 1993, in a wave of perestroika, the new "Fundamentals of the Legislation of the Russian Federation on Health Protection" were adopted. The adoption of those provided a legislative basis for the Russian healthcare transition to a market economy. Medical care turned into a service, the physician became a service provider, and the patient transformed into a client. The doctor-patient relationship was equated to buyer-seller relationship to be covered by the consumer law. Under such circumstances the informed consent was placed in the context of transaction for supply of services between two parties: the service provider was obliged to inform the client about the salient attributes of the service and had no right to impose the service. It was this ideology that was embedded in Article 32 of the Fundamentals, which stated the following: "The person's informed voluntary consent is the requisite preliminary condition for medical intervention". The next 33rd Article of the Fundamentals gave an explanation: "a person or his legal representative shall have the right to refuse the medical intervention or to demand its termination", and "if a person or his or her representative renounces medical intervention, then possible consequences of this decision shall be explained to them in an understandable form". Article 34 permitted providing medical care without the consent "in cases of patients who suffer from contagious diseases and serious psychic disorders or for persons who have committed socially dangerous deeds on the grounds and in the order prescribed by the legislation of the Russian Federation".

Even the cursory glance at the 1993 law made it clear that the law was based on the American bioethical principlism, i.e. the concept based on the development of principles, when the major treasure for the physician was the patient's (consumer's) right to choose freely rather than the patient's well-being. Without being reflected by society in the field of bioethics, these principles were immediately enshrined in the law. It is worth emphasizing that this approach came in some ways as a surprise both for Russian physicians and Russian patients, and the further application of the practice of the informed consent in our country resulted neither from the patients' perceived need for autonomy, nor from the physicians' understanding of their responsibility for implementation of this patient's right. Both patients and physicians passively obeyed the necessity dictated by the law under rather tough administrative pressure. Currently, a checklist of any public auditor contains a section on ensuring respect for patients' rights, in which, for instance, the process of obtaining the informed consent from the patients is verified. Violations of provisions in this section are considered grave violations of the licensing requirements with attendant legal consequences, and constitute a cause for institution of proceedings for administrative offences. An example of judicial ruling is given below.

The female patient with paratonsillar abscess was transported to the hospital ER by ambulance. When examining the abscess, the admitting otolaryngologist saw no abscess and established the diagnosis of lacunar tonsillitis. The febrile patient was transferred to the infectious diseases hospital, where she was provided the necessary assistance. This situation somehow attracted the attention of the inspection bodies, which found out that after examining the patient the physician failed to arrange the medical history properly, and "in violation of the requirements of Article 20 of the Federal Law 1 323-Ф3, when examining the patient, the admitting otolaryngologist did not obtain the informed consent to healthcare intervention (i.e. to examination - author's note). Under these circumstances, the admitting otolaryngologist was subject to administrative proceedings under part 3, Article 19.20 Code of Administrative Offences of the Russian Federation in the form of fine» (from the ruling of the Samara Regional Court $14 a-847 / 2013$ dated November 20, 2013).

Fortunately, our law does not equate provision of medical care without informed consent to violence, in contrast to some states of the USA. However, lack of proper informed consent may by treated by the court as evidence of the physician's under- or non-performance, which is necessary to find him guilty of infliction of injury or the patient's death.

Development of practice of the informed consent under such circumstances resulted in gross distortion of its meaning and in flagrant abuse by healthcare specialists. Adoption of new "Fundamentals of Health Protection of the Citizens in the Russian Federation" in 2011 in order to specify the essential amount of information provided to patient together with the formal characteristics of the consent presentation in the medical documentation, as well as to permit the provision of emergency medical care without patient's consent, did not change the big picture.

What kind of misuse and abuse are we talking about? The epigraph to this part of our paper could be the famous line from the Ivan Krylov's fable "The Wolf and the Lamb": "Always are the weak at fault before the strong". And in fact, the physicians, being the stronger party in the relationship with the patients, quickly discovered the potential of the informed consent process in protecting the physicians' rights. They managed to apportion heavy burden of weighting the risk-benefit ratio and deciding medical intervention to the patient. In the hands of physicians, the informed consent, initially intended to protect the patient against the doctors' high handedness, transformed into the need to make a responsible choice at the worst possible time, when the patient, sick and scared, confused and subservient, was very acutely aware of his or her vulnerability. The situation of shared responsibility arose: "I have already told you about the possible consequences, but it is you who have chosen this surgical procedure..."

The situation was also exacerbated by the fact, that the physician, "tempted by the market" and acting as a service provider, had learned data manipulation in order to sell something that benefits and refuse to sell something that yields losses. In this regard, the appeal to "present and future patients" of oncology clinics is significant. It was posted on Facebook business page in 2018 by Mikhail Laskov, head of the oncology clinic. V. L. Lekhtsier had found the online appeal and quoted it in his paper "Logic of care versus logic of choice in modern concepts of medical practice" (2019) [4]. So, M. Laskov addresses the patients in the following way: "... both major and minor cancer surgery should have two true objectives: life extension (including recovery from cancer, if possible) and the quality of life. Neither "Not up to the challenge?", nor "we are the only ones who...", as well as "and at work..." do not automatically mean that the objectives would be achieved". He further outlines the list of "the most cynical cancer surgical procedures", compares the consent to such procedures with 
"buying false hope", and encourages the patients to make decisions after weighing the pros and cons. The final line of the appeal sums up: "It is not our choice to perform surgery on a dare". This case illustrates the opportunity for profitable "selling the false hope" contrary to the patient's well-being, not violating the patient's right to choose freely.

Physicians, having neglected the truth they were taught since their student days, that in wounded winners the wounds heal faster than in wounded losers, have started, quite relentlessly, to inform the patients about the risks of proposed medical interventions in order to avoid claims. The patients are terrified by the informed consent forms, often consisting of several pages with fine print and full of unclear terms. One female patient said: "I got the impression that I had to sentence myself to death". There are tragic cases where patients failed to stand an emotional blow after being informed about the upcoming intervention (sad story about the death of Y. Yevstigneev, who suddenly passed away after being informed about the high risk of the upcoming surgery by the cardiac surgeon).

We have found another example of the informed consent abuse in "The Diary of a Hospital Security Guard" by Oleg Pavlov, the winner of the Booker Prize [5]. While working at the ER of one of Moscow's hospitals as a security guard, the future writer witnessed the situation directly related to informed consent.

A guy with wet gangrene... His wife and son were there with him, later the oldest pulled up. He was told that leg needed to be amputated, but he refused. He was decent to look at; but it seemed that he had put himself in this situation on his own. He was one of those people that were afraid to do anything, he was afraid of his condition... They went home from the hospital, because they failed to convince the doctors to "just treat him". Mother was whiny and confused, having no courage. The youngest was very passionate - she tortured him, and he obeyed. The oldest arrived in his car, starting immediately to rally, shouted, started to "fix things" with the doctors, although eventually he also failed. The father was whiny quite the same, sort of mollycoddled by the gangrene... But he also shouted, and gave instructions about the infected leg: how to grab it, where to move, and how to bind. When a dressing was applied as a courtesy, he complained, that the dressing was done wrong...

This situation is a demonstration of gruesome indifference to patient, who was in fact denied medical treatment, and, let us be honest, was condemned to death. However, there is no doubt that in case someone asked the physician, if he was sure he fulfilled his medical duty in case of the patient with wet gangrene, he would answer that he certainly did The patient refused surgery, and his refusal was submitted as appropriate. What is the problem? Meanwhile, this case is a typical example of decision making influenced by "vicious will", when experiencing pain, anxiety, and fear have a negative impact on the capacity of mentally healthy person of efficient volitional action control. The "vicious will" is a legal concept; bearing proof of the party vicious will allows the court to declare the deal insignificant. If the patient with gangrene signed both the refusal of amputation and the will, his relatives would have a chance to challenge the will in court referring to vicious will resulting from severe disorder. It's interesting that the patient's decision concerning medical intervention is not queried in a similar situation.

In this case the "refusal submitted as appropriate" freed the physician from the burden of looking after a not very nice patient (based on the description). Although, the patient could be hospitalized, anesthetized, prescribed detoxification and antibiotic therapy, bandaged, as well as comforted and one more time clearly informed about his problem and the need for amputation. But it is a long road; it is much easier to submit refusal.

However, hoping the properly submitted informed consent would protect them, the physicians do not fully understand the real role of this document in case of criminal prosecution or civil claim by the patient. Judicial practice suggests that judges often agree with the claimant, who believes that physicians have mispresented the information, which has made it impossible for the claimant to make a right decision. And if he knew the truth about the proposed intervention or the consequences of refusal, he would make an opposite decision. Some claimants claim that they were unable to understand what was said, that severe pain (shortness of breath, fear, etc.) made concentration difficult, and the physician used unclear terms. Thus, we know about the ER doctor convicted for failure to administer medical treatment, who had accepted the female patient's refusal of proposed assistance. A young woman sitting in the hallway looked strange, and the patients next to her told the physician about it. He came out of the office and asked the woman if she was ok, but heard swearing, which he considered a refusal of assistance. The physician returned to office in order to continue consultations, but two hours later he was told that there was a dead body in the ER. It was that woman, who, according to autopsy, died of severe bilateral pneumonia. Defending himself in court, the physician emphasized that he could not bend the rule of informed consent in case of the patient, who protested strongly against his intervention. The court rejected his explanation, saying, that two hours before her death of pneumonia the patient was likely to have severe hypoxia, and was unable to respond adequately to the offer of assistance.

In addition to overt misuse and abuse, the informed consent, being in most cases a purely formal process, stepped up the bureaucratic pressure on the patients. It is more and more often associated with violence, it raises the mistrust of the doctors and even aggression. In response to the request to submit the form we can hear: "Wanna have your ass wellcovered?" Thus, instead of protecting his right to choose freely, the patient receives senseless (from his perspective) procedure, once more pulling him back from the physician.

To summarize, we can assume that current practice of informed consent in our country does not serve the interests of patients and medical community, and thus should be reviewed. Here we see the process of transformation of bioethical norms, which were prematurely, without preliminary deep thinking and conducting pilot studies enshrined in the law, from the "shield", protecting the patient, into "sword", bringing pain and mistrust (Wolf SM, 2004) [6]. Where do we find the ground for the necessary revision?

\section{Modern ethics seeking the balance between the right to choose and right to care}

In search for carefully managed informed consent process valid in Russia, it may be useful to study the current overseas experience. Currently, in foreign countries this specific issue is being studied: how to combine free choice and care of vulnerable patient. Not only philosophers, but also bioethical practitioners are trying to find the answer. They perform field research involving the informed consent-related ethical dilemmas, solved by medical practitioners and nurses in various clinical situations. The opinion of patients is also being studied. Moreover, the focus is on medical situations when the patient is in the most vulnerable condition and is unable to live without 
assistance and support. Various combinations of choice and care in geriatrics, palliative care, at the stage of establishing diagnosis in oncology care, etc., are being studied

Thus, the paper by J. MacArtney et al, 2017, discusses the ambivalent pastoral model, involving friendly doctor-patient relationship at the stage of establishing the cancer diagnosis, allowing the patient both to choose freely and to accept care provided by the physician [7]. "When the relationship is smooth, I am ready to rely entirely on the expert's view" says one of the surveyed patients. The other female patient told us that after she had found out about her diagnosis, she read the articles on the Internet and the booklets given by the physician. However, she needed to discuss the issue, how the disorder would change her life, and her future. "I searched for a "nanny", who would explain..." The paper by Swartz AK, 2018, upholding the principles of feminist bioethics, discusses the issue of interaction between the physician and the vulnerable patient, and raises the question of impermissibility of the forced autonomy, so prevalent in modern medicine, governed by "male law" [8]. Thus, we are now witnessing the birth of the concept of "relative autonomy" and "limited paternalism", when the relativity and the limits are defined during the interpersonal interaction between the physician and the patient in every particular situation. We would like to call this concept situational ethics.

The only problem is that such concept requires the physician to expend excessive resources, and distracts his attention from solving the problems considered to be purely medical. Moreover, modern physicians are trained to solve such problems; they consider communication with the patients the onerous responsibility, which, strictly speaking, is not a responsibility, but an additional load, from which one wants to escape any way he could in order to descend into "genuine medicine". Most of the physicians disagree to become "merry shepherds" or "careful nannies" for their patients. However, according to research, many patients look for not only free choice, but also for being "coddled" by the physician. Only time will tell how medicine will respond to such requests from the patients, who were "freed" by deprived of care. However, the growing gap of mistrust between the physicians and the patients does not allow us to procrastinate on this issue.

\section{Conclusion}

We will be witnessing reconsideration of the informed consent image, making the informed consent more humanistic in the near future. Even now the novel situational ethics is being formed, assuming that the balance between choice and care is defined during the meaningful interpersonal interaction between the physician and the patient in every particular situation. Perhaps, achieving the balance will require total reconsideration of the doctors' perceptions of their profession, accompanied by significantly stronger humanitarian component of the profession, as well as by changed organizational structure of the healthcare system, which, with a growing number of vulnerable patients (population ageing), will be supplemented by a meaningful sector of humanitarian support for the technology-intensive medical care.

\section{References}

1. Beauchamp TL, Childress JF. Principles of biomedical ethics. Oxford: Oxford university press; 1994; $512 \mathrm{p}$.

2. Christen $\mathrm{M}$, Ineichen $\mathrm{C}$, Tanner $\mathrm{C}$. How "moral" are the principles of biomedical ethics?--a cross-domain evaluation of the common morality hypothesis. BMC Med Ethics. 2014; Jun 17:15-47

3. Mol A., The Logic of Care: Health and the Problem of Patient Choice. London: Routledge; 2008; 166 p.

4. Lehcier VL. Logic of care versus logic of choice in modern concepts of medical practice. Interactive. Interview. Interpretation. 2019; 11(20): 36-53. Russian.

5. Pavlov O. "Diary of the hospital guard." M.: Vremya Publishing
House; 2012; 126 p. Russian.

6. Wolf SM, Law \& bioethics: from values to violence. Journal of Law, Medicine \&Ethics. 2004; 32: 293-306

7. MacArtney Jl, Malmström M, Overgaard Nielsen TL, Evans J., et al. (2017) Patients' initial steps to cancer diagnosis in Denmark, England, and Sweden: what can a qualitative, cross country comparison of narrative interviews tell us about potentially modifiable factors?, BMJ Open, 7, e018210.

8. Swartz AK, A Feminist Bioethics Approach to Diagnostic Uncertainty. Am J Bioeth. 2018; 18(5):37-39 DOI: 10.1080/15265161.2018.1447046. PMID: 29697339

\section{Литература}

1. Beauchamp TL, Childress JF. Principles of biomedical ethics. Oxford: Oxford university press; 1994; 512 p.

2. Christen M, Ineichen C, Tanner C. How "moral" are the principles of biomedical ethics?--a cross-domain evaluation of the common morality hypothesis. BMC Med Ethics. 2014; Jun 17:15-47

3. Mol A., The Logic of Care: Health and the Problem of Patient Choice. London: Routledge; 2008; 166 p.

4. Лехциер В. Л. Логика заботы versus логики выбора в современных концепциях медицинской практики. Интеракция. Интервью. Интерпретация. 2019; 11(20): 36-53. DOI: https:// doi.org/10.19181/inter.2019.20.2.

5. Павлов О. «Дневник больничного охранника». М.: Издательство «Время»; 2012; 126 с.

6. Wolf SM, Law \& bioethics: from values to violence. Journal of Law, Medicine \&Ethics. 2004; 32: 293-306

7. MacArtney JI, Malmström M, Overgaard Nielsen TL, Evans J., et al. (2017) Patients' initial steps to cancer diagnosis in Denmark, England, and Sweden: what can a qualitative, cross country comparison of narrative interviews tell us about potentially modifiable factors?, BMJ Open, 7, e018210.

8. Swartz AK, A Feminist Bioethics Approach to Diagnostic Uncertainty. Am J Bioeth. 2018; 18(5):37-39 DOI: 10.1080/15265161.2018.1447046. PMID: 29697339. 


\section{WHAT DO MEMBERS OF RESEARCH ETHICS COMMITTEES KNOW ABOUT THEIR ORGANIZATIONAL AND OPERATIONAL ASPECTS?}

Chudova NV, Tsyzman LG $\bowtie$

Research Center of Neurology, Moscow, Russia

The article analyzes how well members of research ethics committees (RECs) know the operational and organizational procedures of REC and provides the assessment of standard operational procedures for professional training of REC members.

Keywords: ethics committee, training of specialists, ethical review

$\triangle$ Correspondence should be addressed: Lyubov G. Tsyzman

Petrovsky Boulevar 8, b. 2, Moscow, 127051; Cyzman@expmed.ru

Received: 20.03.2021 Accepted: 26.03.2021 Published online: 31.03.2021

DOI: $10.24075 /$ medet.2021.008

\section{ОСВЕДОМЛЕННОСТЬ СПЕЦИАЛИСТОВ ПО ВОПРОСАМ ОРГАНИЗАЦИИ И ДЕЯТЕЛЬНОСТИ ЛОКАЛЬНЫХ ЭТИЧЕСКИХ КОМИТЕТОВ}

Н. В. Чудова, Л. Г. Цызман $\bowtie$

Научный центр экспертизы средств медицинского применения, Москва, Росия

В статье приведен анализ данных об осведомленности специалистов по вопросам организации и деятельности локальных этических комитетов (ЛЭК). Представлена оценка стандартных операционных процедур ЛЭК, определяющих обучение специалистов.

Ключевые слова: этический комитет, обучение специалистов, этическая экспертиза

$\bigotimes$ Для корреспонденции: Цызман Любовь Геннадьевна,

Петровский бульвар, д. 8 строение 2, Москва, 127051; Cуzman@expmed.ru

Статья получена: 20.03.2021 Статья принята к печати: 26.03.2021 Опубликована онлайн: 31.03 .2021

DOI: $10.24075 /$ medet.2021.008

\section{Introduction}

A research ethics committee (REC) is an autonomous independent voluntary body of specialists, scientists and clinicians with expertise in clinical trials of drugs (CTD).

From the outset of the COVID-19 pandemic, the operational principles of RECs have been subjected to a lot of scrutiny from all levels, including WHO $[1,2,3]$.

In Russia, RECs operate according to the Constitution, other laws and regulations, the Declaration of Helsinki (World Medical Association), the guidelines of the Council for International Organizations of Medical Sciences (CIOMS), and the European Convention on Human Rights and Biomedicine.

Guidance for REC is provided by $\mathrm{WHO}, \mathrm{ICH}$ GCP (International Conference on Harmonization - Good Clinical Practice), the Russian OST 42-511-99 Guidelines for Good Clinical Practice, the approved statute on the Committee, and the system of standard operational procedures (SOP). Oversight is performed by the Federal Service for Surveillance in Healthcare and Social Development (Roszdravnadzor). An inspection carried out by Roszdravnadzor in 2018 uncovered a number of violations in the activities of RECs, which were reported at the Conference on Ethical Challenges of the 21st century held on November 1, 2019 in Moscow as part of the 29th National Congress on Respiratory Diseases: noncompliance with SOP (38\% of the violations), record-keeping and protocol violations (24\%), violations pertaining to the evaluation of qualifications of the researcher (14\%). A review of law implementation practices by Roszdravnadzor revealed that in some cases RECs did not control adherence to ethical norms during the trial, failed to make sure that the rights of study participants were observed, violated the procedures of informing the researcher or CT organizers about the decisions made and reasons for such decisions; in some cases there were not enough qualified experts in REC to carry out the ethical evaluation of the planned trial, or there was no confirmation that scientific consultants involved in decision making had not participated in the debate and voting [4].

\section{Aim of study}

The aim of the study was to evaluate the expertise of REC members in organizational and operational practices of REC and to analyze the system of SOP for REC in the context of decision making about external and in-house training of REC members.

\section{METHODS}

A survey was conducted among 97 members of 22 RECs across Russia (Moscow, Saint-Petersburg, Kazan, Nizhny Novgorod, Barnaul, Novosibirsk, Vladivostok, Belgorod, Omsk, Tomsk, Smolensk, Yaroslavl). The questionnaire contained 16 questions for REC members with expertise in ethics who are responsible for monitoring ethical conduct of $\mathrm{CT}$ and ensuring that the rights of CT participants are observed. The obtained data were processed, analyzed and summarized. Procedures related to the training of REC members were analyzed using a sample of 10 RECs.

\section{RESULTS AND DISCUSSION}

RECs from our sample comprised up to 15 people each. Each of the studied RECs, except those from Moscow and Kazan, reviewed an average of $<10$ projects (initial applications) and 1 to 50 re-submissions, including amendments to the protocol, updated protocols or information leaflets, per month. For Moscow and Kazan RECs, the number of initial submissions 
was higher: 50 to 85 . Generally, submission assessment can be expedited or performed within an established period of time. The following response times were reported: 2 weeks $(40 \%$ of the respondents), one month (20\%) and 10 days (7\%). Of all the respondents, 69\% said their REC had a special peer review template and an established procedure for pre-review of applications; rejection of applications for clinical drug trials was reported by $51 \%$ of the respondents. However, the respondents did not specify whether regulatory agencies (Scientific Centre for Expert Evaluation of Medicinal Products and Council on Ethics of the Ministry of Healthcare) had reviewed the rejected applications prior to REC decision. Twenty-seven percent of the respondents said they knew about cases when REC members had decided to terminate a clinical trial.

All of the respondents (100\%) claimed that they strictly adhered to the established SOP, which is a mandatory requirement for an ethics committee at any medical facility; this requirement is specified in the Order 200n of the Ministry of Healthcare dated April 1, 2016. The procedure of granting the sponsor of $\mathrm{CT}$, the researcher and regulatory agencies unlimited access to SOP and REC members data was familiar to $100 \%, 93 \%$ and $97 \%$ of the respondents, respectively. Some of the respondents (36\%) believed that patients or their family members should be invited to participate in REC meetings in order to organize CT more effectively, because their opinion about the tested drug is based on personal experience. Fifty-nine percent of the respondents said that the applicant/ sponsor/researcher could participate in the discussion of specific issues during a REC meeting only if they had permission of the chairman/deputy chairman; $32 \%$ said that only clinicians/researchers themselves could participate in REC debate; $9 \%$ said that the applicant/sponsor/researcher could not participate in a REC meeting. Over $7 \%$ of REC members reported that independent consultants participated in the vote during a REC meeting.

As part of our study, we analyzed documentation provided by 10 RECs describing how training of REC members should be organized in order to improve the quality of ethics expertise.

In 2 cases (20\%), Kazan State Medical University and Sechenov First Moscow State Medical University introduced the concept of internship to REC. A person who wants to become a REC member signs the confidentiality agreement and gets access to all REC documents. The intern is allowed to be present at all REC meetings but cannot participate in voting. At Kazan State Medical University, such internship lasts for 2 months; at Sechenov First Moscow State Medical University, it lasts at least 1 year. During this period, the intern learns about GCP and ethics expertise. Upon completing their internship, the intern receives a certificate and becomes a full-fledged REC member $[5,6,7]$. In our study, $30 \%$ of RECs (3 cases) did not have a provision about the training program for REC members in SOP; in 3 cases (30 \%) it was impossible to assess how training procedures were implemented due to the absence of publicly available information about SOP on the web-site of the institution. Only in 2 cases (20\%) SOP outlined the duties and responsibilities of those REC members who would be in charge of organizing educational programs on medical ethics and take a training course/internship program to improve their own qualifications.

\section{CONCLUSION}

The survey shows that most of our respondents knew how RECs operate. Only a few respondents (7\%) did not have full knowledge of REC procedures (participation of independent consultants in the vote, participation of the applicant/ researcher/sponsor in the discussion, considering the existing conflict of interests, granting the researcher and regulatory agencies unlimited access to SOP and REC members data, etc).

Continuous education of REC members and maintenance of corporate culture are essential tasks for any medical facility. The analysis of REC documentation revealed that $1 / 3$ of SOP did not contain information about REC members training. Besides, in $30 \%$ of cases it was impossible to assess decisions on training procedures made by REC due to their unavailability to the public.

The role of REC is becoming more significant during the current coronavirus pandemic, when ethics committees are more focused on post-registration studies and positive/ negative effects of trialed drugs need to be scrutinized.

Thus, additional training programs for members of ethics committees are needed to reduce the rate of errors in expert assessments, ensure high quality of clinical trials and guarantee safety of their participants.

\section{References}

1. World Health Organization (2020). Ethical standards for research during public health emergencies: Distilling existing guidance to support COVID-19 R\&D. https://www.who.int/blueprint/prioritydiseases/key-action/liverecovery-save-of-ethical-standards-forresearch-during-public-health-emergencies.pdf/.

2. World Health Organization. 2020. 2019 novel Coronavirus: Global research and innovation forum: towards a research roadmap. https://www.who.int/blueprint/priority-diseases/key-action/ Roadmap-version-FINAL-for-WEB.pdf?ua=1/.

3. World Health Organization. Guidance for research ethics committees for rapid review of research during public health emergencies. 28 May 2020: https://www.who.int/publications/i/ item/9789240006218/.

4. Review of the law enforcement practice of control and supervision activities of Roszdravnadzor for the 2nd quarter of 2018. https:// www.roszdravnadzor.ru/discussion/control/prevention/doc7/.

5. Regulation on the local ethics Committee, version 2.0. from 25.10.2017. https://www.sechenov.ru/upload/iblock/30a/ polozhenie-lek-versiya-2.0.pdf/ Russian.

6. The Standard operating procedure of The Local ethics committee of Kazan State Medical University. https://kazangmu.ru/scienceand-innovation/lokalnyj-eticheskij-komitet/main-doc/. Russian.

7. Resolution of the Government of the Russian Federation of April 3, 2020 № 441. https://www.garant.ru/products/ipo/prime/doc/73750814/

\section{Литература}

1. World Health Organization (2020). Ethical standards for research during public health emergencies: Distilling existing guidance to support COVID-19 R\&D. https://www.who.int/blueprint/priority-

diseases/key-action/liverecovery-save-of-ethical-standards-forresearch-during-public-health-emergencies.pdf/.

2. World Health Organization. 2020. 2019 novel Coronavirus: Global 
research and innovation forum: towards a research roadmap. https://www.who.int/blueprint/priority-diseases/key-action/ Roadmap-version-FINAL-for-WEB.pdf?ua=1/.

3. World Health Organization. Guidance for research ethics committees for rapid review of research during public health emergencies. 28 May 2020: https://www.who.int/publications/i/ item/9789240006218/.

4. Обзор правоприменительной практики контрольнонадзорной деятельности Росздравнадзора за 2 квартал
2018 года. https://www.roszdravnadzor.ru/discussion/control/ prevention/doc7/.

5. Положение о локальном этическом Комитете, версия 2.0 от 25.10.2017. https://www.sechenov.ru/upload/iblock/30a/ polozhenie-lek-versiya-2.0.pdf/.

6. СОП ЛЭКККГМУ, Редакция 8 от 10.12.2018 г. https://kazangmu ru/science-and-innovation/lokalnyj-eticheskij-komitet/main-doc/.

7. Постановление правительства РФ от 3 апреля 2020 г. № 441. https://www.garant.ru/products/ipo/prime/doc/73750814/. 